\title{
A REPRESENTAÇÃO DO VAZIO NO COTIDIANO
}

Dissertação apresentada ao Programa de Pós-Graduação em Artes, Área de Concentração Artes Plásticas, Linha de Pesquisa Poéticas Visuais, da Escola de Comunicações e Artes da Universidade de São Paulo, como exigência parcial para obtenção do Título de Mestre em Artes, sob a orientação do Prof. Dr. Geraldo de Souza Dias.

São Paulo 

Banca Examinadora 



\section{Agradecimentos}

Ao Prof. Dr. Geraldo de Souza Dias, pela orientação.

Aos membros da banca de qualificação, Prof. Dr. Carlos Fajardo e Prof. Dr. Sérgio Romagnolo, pelas contribuições.

Ao Prof. Dr. Carlos Eduardo Uchôa e Prof. Dr. Marco Giannotti.

À minha família, Arnaldo, Lucila, Marcos e Mariana.

Aos amigos Fernando Forte, Louise Deroualle, Lourenço Gimenes, Luis Fernando de Almeida e Rodrigo Marcondes Ferraz. 



\section{Resumo}

Esta dissertação apresenta uma reflexão sobre a minha produção artística desenvolvida ao longo dos últimos anos que tem como preocupação central a relação entre os conceitos de cotidiano, vazio e criação.

O objetivo deste texto é entender de uma maneira abrangente o processo de criação do conjunto de obras apresentado, identificando e organizando os motivos que levaram à sua criação, os conceitos envolvidos, elementos e técnicas utilizadas para sua materialização.

As questões referentes aos conceitos de cotidiano e vazio são apresentadas e discutidas, relacionando-as com o processo criativo e demais procedimentos próprios do fazer artístico.

\section{Abstract}

This dissertation presents a reflection on my artistic production developed over the last years, which has as central concern the relation between the concepts of everyday-life, emptiness and creation.

This text aims to explore in a comprehensive manner the issues involved during the creation of the presented works, identifying and organizing the reasons that led to the creation of these works, the concepts involved, the elements and techniques used for their materialization.

The issues referring to the concepts of everyday-life and emptiness are presented, examined and related to the creative process and others art procedures.

Palavras-chave: arte contemporânea, cotidiano, ausência, vazio, pintura. 



\section{Sumário}

1. Apresentação 10

2. Cotidiano 12

$\begin{array}{ll}\text { Vida Cotidiana } & 12\end{array}$

Momentos de Lazer $\quad 14$

$\begin{array}{ll}\text { 3. Vazio } & 17\end{array}$

$\begin{array}{ll}\text { A Percepção do Ausente } & 17\end{array}$

$\begin{array}{ll}\text { O Vazio que nos Concerne } & 18\end{array}$

$\begin{array}{lr}\text { Cesura } & 20\end{array}$

4. O Exemplo de Morandi 24

5. Questões da Imagem 27

Índice $\quad 29$

$\begin{array}{ll}\text { Fotografia } & 30\end{array}$

Pintura Fotorrealista 32

Imagem-objeto 34

6. Arte, vida e ausência 36

A Pintura da Ausência 36

7. Obras 41

8. Considerações Finais 79

$\begin{array}{ll}\text { Bibliografia } & 82\end{array}$ 



\section{Apresentação}

Esta dissertação de mestrado apresenta uma reflexão sobre o trabalho plástico produzido ao longo dos últimos anos que, apesar dos variados resultados formais, partiu de uma única preocupação, a relação entre os conceitos de cotidiano, vazio e criação.

Tendo em vista que o objetivo aqui proposto é entender de uma maneira abrangente os aspectos envolvidos neste processo de criação, evito focar exclusivamente apenas um dos conceitos trabalhados, o que restringiria a compreensão do trabalho plástico como um todo. Por isso, optei por apresentar tais conceitos - fundamentados em textos de diversos autores - em suas relações, as quais dão origem às obras plásticas.

Sendo a produção plástica o objeto central deste trabalho, apresento um conjunto de obras representativas desenvolvidas ao longo da trajetória artística, desde o início da produção até o momento de elaboração desta dissertação. Partindo de um questionamento sobre esta produção, o texto que segue tem o objetivo de identificar, organizar e entender os motivos que levaram à criação destas obras, os conceitos envolvidos, os caminhos do processo criativo, os elementos e técnicas utilizadas para a materialização destes conceitos e os resultados obtidos. $O$ conhecimento gerado a partir desta reflexão servirá de embasamento para uma produção mais consciente e consistente, aprofundando e enriquecendo o trabalho plástico.

O desafio que permeia a elaboração deste texto é traduzir, em um trabalho acadêmico, no qual a investigação deve ser apresentada de maneira organizada e clara, uma atividade cujo processo de criação e desenvolvimento raramente é linear e que geralmente falha em ser transmitida verbalmente. Nesse processo, muitas vezes o intuitivo tem um peso predominante e que parece não conviver com qualquer elemento objetivo em sua elaboração.

Na tentativa de organizar esta reflexão de uma maneira clara e objetiva, apresento este texto dividido em tópicos, os quais são fundamentais dentro deste trabalho. São eles: Cotidiano, Vazio, O Exemplo de Morandi, Questões da Imagem e Arte, Vida e Ausência. Cada um desses capítulos terá seu foco voltado para o tema 
que the intitula, desenvolvendo seus conceitos, relacionado-os com os demais tópicos deste trabalho e confrontando-os com as obras plásticas.

A pesquisa teórica tem seu inicio com a apresentação e aprofundamento sobre as questões relativas ao Cotidiano, este elemento que de tão próximo torna-se de difícil compreensão, refletindo sobre suas características e sua importância para a atividade criativa, que muitas vezes passa despercebida. Logo a seguir abordo o conceito do Vazio, sua percepção, suas possibilidades, seu papel fundamental para a transcendência do cotidiano e sua representação no trabalho plástico.

Após estes dois capítulos introdutórios, aproveito o Exemplo de Morandi para mostrar, a partir do trabalho deste artista que tomo como referência, as possibilidades criativas concebidas através da relação entre os conceitos do vazio e cotidiano apresentados nos capítulos anteriores. Questões da Imagem parte do questionamento sobre a variedade de processos para criação de imagens presente em meu trabalho e propõe uma análise de como cada tipo de imagem se relaciona com os conceitos básicos que motivaram sua produção.

Completo esta reflexão teórica contextualizando historicamente meu trabalho em Arte, Vida e Ausência. Neste capítulo faço um breve levantamento histórico ponderando sobre o momento de reaproximação da arte à vida, levando em consideração as questões trabalhadas pela Arte Pop e sua repercussão na arte desenvolvida a partir de então, focando principalmente na ideia de que toda pintura que se utiliza da imagem fotográfica amplifica as questões do vazio presente em sua materialização.

Antes de finalizar, fazendo as Considerações Finais desta dissertação, apresento um conjunto de imagens das obras mais significativas, que serviram como ponto de partida para este estudo, organizado de maneira a permitir uma melhor compreensão do desenvolvimento do trabalho e de seus conceitos. 


\section{Cotidiano}

\section{$\underline{\text { Vida Cotidiana }}$}

Qualquer atividade na qual o homem esteja comprometido, desde a tarefa mais humilde executada mecanicamente, quase sem se perceber, até as descobertas científicas e obras criativas, tem origem na vida cotidiana. Definir o cotidiano apenas como aquilo que acontece todos os dias é, sem dúvida, muito impreciso.

A pesquisadora Christiane Peyre apresenta uma definição de cotidiano na qual as atividades banais e aparentemente sem importância do dia a dia estão vinculadas a objetivos maiores e fundamentais ao desenvolvimento humano. Segundo Peyre, podemos definir o cotidiano como "o conjunto de atividades cuja necessidade resulta de um processo geral de desenvolvimento: evolução, crescimento e envelhecimento, proteção biológica ou social, processos esses que escapam da compreensão imediata e que só são perceptíveis em suas consequências" ${ }^{1}$.

O sociólogo francês Henri Lefebvre (1901-1991) complementa as ideias de Peyre caracterizando o cotidiano como o meio através do qual o homem exerce ativamente a transformação histórica e social de seu mundo:

O mundo perceptível é, na realidade, o produto da ação humana no nível histórico e social. A atividade que dá forma ao mundo externo não é uma atividade mental, teórica ou formal, mas sim uma atividade concreta. Ferramentas práticas, não simples conceitos, são os meios com os quais o homem dá forma ao mundo perceptível. (...) Portanto, o mundo é o espelho do homem, já que ele o constrói: é função de seu cotidiano construí-lo. Mas não é seu espelho de uma maneira passiva. Em seu trabalho o homem percebe e se torna consciente de si mesmo. Se o que ele faz vem dele, ele vem do que ele faz; é feito por ele, mas é nesses trabalhos e por esses trabalhos que ele próprio se faz. ${ }^{2}$

1 PEYRE, Christiane apud LEFEBVRE, Henri. Critique of Everyday Life II - Foundations for a Sociology of the Everyday. London: Verso, 2008. p.42. Tradução minha. Citação feita por Lefebvre retirada de um relatório enviado por Christiane Peyre, pesquisadora do Centre National de la Recherche Scientifique (CNRS), ao Groupe d'Études de Sociologie de la Vie Quotidienne, Centre d'Etudes Sociologiques.

2 LEFEBVRE, Henri. Critique of Everyday Life I - Introduction. London: Verso, 2008. p.163. Tradução minha 
No entanto, a ideia que o termo "cotidiano" pode evocar na maioria das vezes é a de uma repetição de fatos insignificantes causadora de tédio e indiferença. Como vimos em Peyre, dificilmente temos a consciência da importância dos acontecimentos da vida trivial se não nos distanciarmos dela o suficiente para ver seus resultados a um longo prazo. E, somando-se o fato de que o "hábito e familiaridade gradualmente embaçam nossa curiosidade e nos traz uma confortável indiferença"3, a vida cotidiana é percebida como o lado mesquinho, maçante e infrutífero da vida. Desta forma, podemos perceber a ambiguidade que o cotidiano carrega. Este se apresenta numa aparência de estabilidade, que nos traz a segurança e conforto de eventos previsíveis, dos quais podem aflorar resultados superiores e inesperados.

Para ser criativo ou alcançar algum feito superior, o homem deve se comprometer com seu objetivo e trilhar um caminho em direção a este. A conquista deste objetivo condensa o cotidiano de um longo exercício, no qual todos os procedimentos, desde os mais banais e aparentemente sem vínculo algum com a atividade, mostram-se indispensáveis. Desta forma, mesmo que nenhuma das atividades criativas possa ser reduzida a um mero elemento da vida cotidiana, não é possível separá-las desse cotidiano. A vida cotidiana é um terreno fértil para estas atividades, onde as ideias surgem, se desenvolvem e se materializam. Segundo Lefebvre, "é no coração do cotidiano que projetos se tornam obras de criatividade"4 Sendo assim, este elemento mesquinho e ordinário da nossa vida não é sem importância em relação aos sonhos, aos ideais ou à criação. Ele aparece como um "trampolim para ações sublimes" 5 .

Para que o homem transcenda o contexto da vida cotidiana e se torne um ser criativo, é fundamental que surja um elemento modificador. Para Lefebvre, a necessidade definida como querer é o ponto de partida do qual o homem começa a explorar um mundo de possibilidades, criando-as, escolhendo entre elas e tornandoas realidade ${ }^{6}$. "Quanto mais necessidades um ser humano tem, mais ele existe"7, complementa o autor.

Idem. Ibidem. p.243.

Idem. Critique of Everyday Life II - Foundations for a Sociology of the Everyday. London: Verso, 2008. p.41. Tradução minha.

Idem. Ibidem. p.42.

Idem. Ibidem. p.5.

Idem. Critique of Everyday Life I - Introduction. London: Verso, 2008. p.161. Tradução minha. 
Tomo estas ideias para ilustrar a base de meu trabalho, a relação entre os conceitos de cotidiano e vazio. O trabalho se desenvolve em séries, ou seja, objetos que já tiveram uma função doméstica são colecionados, retratados diversas vezes e apresentados de forma que a repetição do tema esteja em evidência, simulando a cadência da vida cotidiana.

Busco, por meio de objetos, espaços, imagens vulgares muito próximas da experiência diária, representar este lado da vida que, de tão próximo, nos parece tão desinteressante.

Levando em consideração a ideia de que, segundo o filósofo norteamericano Arthur Danto, representação é "algo que está no lugar de outra coisa"8, estes trabalhos criam um distanciamento entre observador e objeto. Como comentado anteriormente, é necessário nos distanciarmos da vida cotidiana para entender seu significado. Desta forma, estas representações propõem uma compreensão diferenciada dos elementos do dia a dia, criando a possibilidade de enxergá-los como produtos grandiosos e sublimes. "Talvez um dos principais serviços que a arte nos presta não seja tanto o de representar o mundo quanto o de apresentá-lo de determinada maneira e de uma perspectiva especial"9.

O objetivo, ao lidar com as imagens que apresento nestes trabalhos, é carregá-las com um forte senso de privação. Apesar de estes recortes do dia a dia remeterem aos nossos espaços entulhados, nossa vida atarefada ou nossa coleção de objetos utilitários, é revelando uma privação presente em nosso cotidiano que pretendo abrir espaço para um vazio, elemento gerador de um querer, fundamental para a criação. Deste modo, garrafas, paredes, móveis, sarjetas, caixas, elementos bastante reconhecíveis do dia a dia - esvaziados, deslocados de seu contexto original e apreciados a certa distância — deixam de ser meros objetos comuns para se impregnarem com novas possibilidades de significados e assim transcender a vida cotidiana.

\section{Momentos de Lazer}

Os momentos de lazer e celebração funcionam como a crítica do homem comum ao seu próprio cotidiano. Estes momentos se apresentam como uma

DANTO, Arthur. A Transfiguração do Lugar-comum. São Paulo: Cosac Naify, 2005. p.56.

Idem. Ibidem. p.246. 
tentativa de escape do cotidiano, mas falham em se desconectar deste, tornando-se parte integrante da vida cotidiana. Segundo Lefebvre,

A relação entre lazer e cotidiano não é tão simples e não pode ser reduzida a mera relação entre domingos e dias de semana. O lazer não pode ser separado do trabalho. Após o término do trabalho, descansando, relaxando ou se ocupando da maneira que desejar, o homem continua o mesmo homem. Todo dia, à mesma hora, operários deixam a fábrica, funcionários deixam os escritórios. Toda semana, sábados e domingos são entregues ao lazer tão regularmente como o trabalho do dia a dia. ${ }^{10}$

Em Notas Escritas em um Domingo na Zona Rural Francesa, Lefebvre apresenta uma reflexão sobre os festivais camponeses desde a civilização grega. Eram festivais que consistiam basicamente em uma grande refeição com muitos divertimentos, como danças, corridas, competições, concursos de beleza e insultos entre as comunidades vizinhas. As festividades podiam acabar em brigas e orgias. Estas festividades camponesas, além de estreitar relações sociais, davam vazão a todos os desejos que estavam contidos pela disciplina coletiva e necessidades do trabalho do dia a dia. Estes eventos se diferenciavam da vida cotidiana apenas por esta explosão de forças que foram lentamente acumuladas no cotidiano. No entanto, para que esses festivais viessem a acontecer, cada camponês fazia grande sacrifício, já que em apenas um dia de festa consumiam-se provisões e estoques que levavam meses para acumular. Esta exuberância sem limites não vinha sem um mau pressentimento: se o inverno seguinte fosse muito rigoroso ou o verão muito seco, a comunidade se arrependeria desse dia de exaltação ${ }^{11}$. Portanto, mesmo no dia no qual eram permitidas a liberação pessoal e coletiva e a experiência da exaltação, não era possível vivenciar uma quebra plena com a vida diária. 0 camponês era novamente tragado pelas aflições do cotidiano.

Mesmo assim temos a ideia de que os momentos de lazer devem oferecer uma fuga do dia a dia. Estes momentos surgem como que urgentes, buscando um excesso de estímulos que não é comum no cotidiano. Música, bebidas e confraternizações costumam estar sempre presentes nessas horas felizes. Fazendo referência a estes momentos específicos e contraditórios da vida cotidiana, alguns

10 LEFEBVRE, Henri. Critique of Everyday Life I - Introduction. London: Verso, 2008. p.29 e 30. Tradução minha.

11 Idem. Ibidem. p.201 e seguintes. 
trabalhos aqui apresentados focam as brechas existentes nesses excessos de final de semana.

Alguns desses trabalhos são intitulados Amplificadores (Figs. 34 a 36). Trata-se de um conjunto de desenhos de grafite sobre papel onde identificamos o formato da área do amplificador de onde o som provém completamente preenchido pelo rabiscar do lápis grafite. Esta técnica, inicialmente utilizada nos trabalhos Espaços (Figs. 22 a 24), apresenta o ato de rabiscar - um trabalho silencioso, demorado, repetitivo e maçante - bastante perceptível, indicando uma repetição muito similar ao próprio cotidiano, num ritmo nem um pouco fluido ou prazeroso como se espera do som que essas caixas acústicas deveriam emanar. A intenção presente nestas obras é representar a natureza dúbia dos momentos de lazer que nunca se destacam completamente da vida comum e disciplinada do cotidiano. Marcas bastante populares de amplificadores são usadas para que, uma vez reconhecidas pelo observador, este possa relacioná-las com experiências vinculadas ao lazer, comemoração, prazer, etc. No entanto, os indícios de trabalho, tempo e repetição, presentes no rabiscar do desenho, abrandam o sentimento de celebração, jogando-o novamente no cotidiano.

Festa! (Fig. 39) é o início de uma série de pinturas em óleo sobre tela executadas com cuidado fotorrealista. Nesta imagem vemos o fundo de uma garrafa de bebida alcoólica - neste caso uma garrafa de cerveja - já vazia. Assim como em Amplificadores, a característica ambígua dos momentos de lazer está representada. A menção sonora do título - a expressão da palavra com grande entusiasmo - choca-se com a imagem do resto de uma festa. Este objeto, assim como o próprio título, indica momentos de prazer, atiçando a apreensão para resgatar na memória imagens de situações similares. Ao mesmo tempo, esta imagem vazia remete ao momento no qual o choque entre lazer e cotidiano se apresenta da maneira mais explícita possível. A comemoração deixa de ser lazer e volta a ser exclusivamente trabalho, o fim de festa, quando a música acaba, as pessoas se vão, e só resta se preparar para a limpeza e retomar o dia a dia. Esta imagem, assim como os demais trabalhos apresentados nesta dissertação, carrega, na privação presente nela, um pouco do "segredo do cotidiano descontentamento" ${ }^{12}$.

${ }^{12}$ Idem. Ibidem. p.35. 


\section{Vazio}

\section{$\underline{\text { A Percepção do Ausente }}$}

Os espaços vazios em minha obra são aqueles que se fazem supor que deveriam estar preenchidos. Artefatos como potes, garrafas, caixas, gavetas, etc., por sua natureza, apresentam-se como receptáculos desses vazios, e, portanto, espera-se que tais espaços recebam ou guardem algo. Além disso, estes são artefatos encontrados no cotidiano, cumprindo sua função de conservar algo, mas que aqui são retratados exibindo uma privação da presença do seu conteúdo. Sendo assim, por remeter a objetos que supostamente já estiveram ou que deveriam estar nesses espaços e que não estão, é possível entender o vazio que estas imagens apresentam como ausência.

Estes fragmentos do cotidiano, através de suas características próprias ${ }^{13}$, apresentam uma plenitude de $\operatorname{ser}^{14}$. No entanto, ao observar estas cenas, os objetos que delas fazem parte oscilam entre figura e fundo, criando uma expectativa que permite a percepção do objeto ausente. Afinal, a não-presença surge a partir de uma espera, de uma possibilidade de presença. Segundo o filósofo francês Jean-Paul Sartre (1905-1980), "é preciso notar que, na percepção, ocorre sempre a constituição de uma forma sobre um fundo. Nenhum objeto, nenhum grupo de objetos está especificamente designado para organizar-se em fundo ou forma: tudo depende da direção da minha atenção"15. Portanto, estes objetos presentes nestes recortes, apesar de funcionarem como fundo para o objeto ausente, estão continuamente alternando sua posição, tangenciando a forma em primeiro plano e deslizando novamente para o fundo. Ou seja, ao mesmo tempo em que estes objetos presentes são fundo, são também determinantes para a definição da forma ausente. É no momento em que estes objetos definem a forma do não-presente, tornando esta ausência perceptível ao observador, que estes objetos presentes diluem-se e assumem uma organização sintética de fundo.

\footnotetext{
13 Segundo Sartre "o fenômeno do ser não é o ser. Mas indica o ser e o exige." SARTRE, Jean-Paul. O Ser e o Nada - Ensaio de Ontologia Fenomenológica. Petrópolis: Vozes, 2008. p.36.

14 "O ser é opaco a si mesmo exatamente porque está pleno de si. Melhor dito, o ser é o que é." SARTRE, Jean-Paul. O Ser e o Nada - Ensaio de Ontologia Fenomenológica. Petrópolis: Vozes, 2008. p.38.

15 SARTRE, Jean-Paul. O Ser e o Nada - Ensaio de Ontologia Fenomenológica. Petrópolis: Vozes, 2008. p.50.
} 
Sendo assim, estas representações do objeto ausente trazem em seu cerne a questão da nadificação ${ }^{16}$. Ao buscar pela presença de um ente ocorre uma nadificação, e esta "nadificação de todas as formas, que aparecem e submergem na total equivalência de fundo, é condição necessária à aparição da forma principal”17. Só assim é possível dizer que o objeto de interesse não está. O objeto faltante se destaca como nada sobre o fundo de nadificação. De modo que "é oferecida à intuição uma espécie de ofuscação do nada, é o nada do fundo, cuja nadificação atrai e exige a aparição da forma, é a forma 'nada', que desliza na superfície do fundo como nada"18. É através dessa dupla nadificação que o vazio da ausência se instaura na percepção.

\section{$\underline{\text { O Vazio que nos Concerne }}$}

Apesar de ter embasamento no subjetivo, já que depende de uma expectativa por parte do sujeito para acontecer, a percepção da ausência ocorre sobre um fundo de existência, remetendo mais ao mundo tangível do que às questões próprias do observador. Esta ausência seria, portanto, um vazio que tende ao mundo objetivo, mesmo que originária nas questões subjetivas.

No entanto há outro vazio a ser analisado nesta pesquisa - um vazio essencial existente na relação entre o sujeito e as coisas. Trata-se de um vazio que se relaciona diretamente com o subjetivo através do ato de ver.

Ao discorrer sobre o ato de ver, o filósofo francês Georges Didi-Huberman, estabelece que "o objeto, o sujeito e o ato de ver jamais se detêm no que é visível"19. Este parece ser o ponto de partida para uma reflexão na qual DidiHuberman demonstra que o mais simples ato de ver se abre em uma complexidade que vai além da materialidade de um objeto.

Trata-se de uma "cisão do ver" ${ }^{20}$. Há aquilo que vejo, ou seja, a evidência de um volume e, por outro lado, há aquilo que me olha, e o que me olha não tem mais nada de evidente, uma vez que se trata de uma espécie de esvaziamento. Um

\footnotetext{
16 Termo criado por Sartre e usado em O Ser e o Nada que deriva da palavra nadificar.

17 SARTRE, Jean-Paul. O Ser e o Nada - Ensaio de Ontologia Fenomenológica. Petrópolis: Vozes, 2008. p.50. Fazendo um paralelo e re-contextualizando o exemplo citado por Sartre de seu suposto encontro com um conhecido para discorrer sobre a percepção da ausência.

18 Idem. Ibidem. p.51. Novamente um paralelo e re-contextualização do exemplo supracitado.

19 DIDI-HUBERMAN, Georges. O que vemos, o que nos olha. São Paulo: Editora 34, 1998. p.76.

20 Idem. Ibidem. p.29 e seguintes.
} 
esvaziamento que de modo nenhum concerne mais ao mundo do artefato ou simulacro, perturbando a capacidade de simplesmente ver. ${ }^{21}$

$\mathrm{O}$ ato de ver, portanto, oscila entre estes dois extremos: o que vemos - a ação de perceber o real - e o que nos olha. Este, o que nos olha, inquieta o ato de ver. Isto se dá através deste esvaziamento, que se origina na cisão do ver, momento no qual o objeto, por mais simples e específico que possa se apresentar ao olhar, se esvazia evocando novas imagens. O objeto sofre um esvaziamento para então enchê-lo de imagens, que o olhar - de maneira nenhuma puro, em estado selvagem ou livre de referências pessoais - carrega. Este é o vazio que nos concerne. Através dele, ao olhar algo, enxerga-se memórias, aspirações, ou qualquer outro elemento existente em nosso subjetivo, projetado e fixado no objeto observado.

O relato de Sigmund Freud (1856-1939) sobre a experiência de ausência vivida pela criança que se transfere para o jogo com o carretel, dando a ela o papel ativo na brincadeira do desaparecimento e retorno - acompanhados respectivamente pelas interjeições Fort! e Da! ${ }^{22}$ —, permite a Didi-Huberman interpretar que "é no momento mesmo em que se torna capaz de desaparecer ritmicamente, enquanto objeto visível, que o carretel se torna imagem visual" ${ }^{23}$.

A criança agora opera este esvaziamento, controlando o ritmo com o qual o carretel desaparece sob a cortina e reaparece com o puxar do fio, sendo que esse fio atua como um rastro do objeto que não permite que ele desapareça por completo. O jogo da criança concede ao carretel - este objeto comum e neutro uma condição de fragilidade, já que a qualquer momento ele pode de fato desaparecer. O carretel é carregado com um poder de alteração permitindo essa oscilação fundamental para a criação de imagens que remetem, neste caso, unicamente à própria criança, através da obra da perda.

\footnotetext{
21 Idem. Ibidem. p.37 e 38. Este parágrafo toma como referência o exemplo dado pelo autor em que o olhar se depara com a questão do volume e do vazio de um túmulo. O que vê refere-se ao volume propriamente dito, de pedra talhada. O que o olha parte do esvaziamento decorrente da cisão do ver e diz respeito ao destino do corpo que jaz oculto neste volume. "Nossas imagens são mais diretamente coagidas ao que o túmulo quer dizer, isto é, ao que o túmulo encerra. Eis por que o túmulo, quando o vejo, me olha até o âmago".

22 FREUD, Sigmund. Edição Stand Brasileira das Obras Psicológicas Completas de Sigmund Freud. Volume XVIII. Além do Princípio de Prazer, Psicologia de Grupo e Outros Trabalhos. Rio de Janeiro: Imago Editora, 1969. p.25 e seguintes.

${ }^{23}$ DIDI-HUBERMAN, Georges. O que vemos, o que nos olha. São Paulo: Editora 34, 1998. p.83.
} 


\section{$\underline{\text { Cesura }}$}

Diante do exposto, encontro suporte nos textos desses autores para legitimar o conceito desenvolvido nos trabalhos plásticos que apresento. Parto da representação de imagens cotidianas, tão comuns e conhecidas quanto um carretel, nas quais o vazio da ausência é percebido através de um rastro do objeto ausente, "fazendo juntar-se no exercício do olhar, um luto e um desejo" ${ }^{24}$, ou seja, permitindo que o olhar se carregue com uma privação e um querer, elementos necessários para transcender o cotidiano, conforme visto anteriormente.

A transcendência do homem cotidiano, portanto, demanda esta lacuna, esta pequena fresta branca que, a partir de seu vazio - que joga com privação e querer —, apresenta-se como uma plenitude de possibilidades. No entanto, levando-se em conta o caráter repetitivo e rítmico do cotidiano, isto, que identifico fisicamente como uma lacuna, adquire as características da cesura. Cesura é um jargão do vocabulário dos críticos de música e poesia para designar um corte, uma suspensão, um momento de silêncio. "A cesura é vista como uma espécie de solução de continuidade, uma interrupção no fluxo vivido de representações a partir da qual um movimento novo pode iniciar" 25.

É buscando ou provocando cesuras que baseio minha atividade criativa de maneira a propor o vazio como um espaço reservado à sublimação, repleto de possibilidades, permitindo a transcendência do homem em um ser criativo ao acolher as imagens por ele geradas. É o vazio aberto pela cesura, fincado na oscilação rítmica do cotidiano, que olha o homem do dia a dia.

Nos trabalhos intitulados Cubos Brancos (Figs. 7 a 10 e 16 a 21), a cesura foi provocada diretamente sobre os próprios elementos cotidianos. Primeiramente a série foi executada como intervenções urbanas nas quais as faces de cubos brancos foram pintadas pela cidade (Figs. 7 a 10) e mais tarde os cubos brancos foram inseridos - com sua própria materialidade: a massa corrida e a tinta acrílica que fazem o acabamento da superfície das paredes das galerias de arte - em espaços íntimos, o mobiliário doméstico (Figs. 16 a 21).

\footnotetext{
24 Idem. Ibidem. p.254.

25 MACIEL, Auterives. A Experiência do Vazio no Pensamento Vista a Partir de Considerações da Filosofia Heideggeriana, in: DA POIAN, Carmen. Formas do Vazio: Desafios ao Sujeito Contemporâneo. São Paulo: Via Lettera Editora, 2001. p.151.
} 
O título dos trabalhos faz uma clara referência ao texto No Interior do Cubo Branco: A ideologia do Espaço da Arte, de autoria do artista e escritor irlandês Brian O'Doherty, e aproveito o raciocínio por ele apresentado para relacionar estes espaços, reservados à arte a partir do Modernismo, com a ideia de criar um espaço utopicamente vazio no qual "o mundo exterior não deve entrar" ${ }^{26}$, "sem sombras, branco, limpo, artificial"27. Segundo O’Doherty, "concluída a retirada de todo o conteúdo perceptível, a galeria torna-se um espaço nulo, mutável ao infinito" ${ }^{28}$.

O espaço da galeria é projetado de maneira a criar um vazio que evite qualquer elemento que possa interferir na apreciação da obra de arte. No entanto, trata-se de um vazio ativo. Este cubo de paredes brancas é um vazio que nos olha, pois "seu conteúdo constitui-se de projeções mentais baseadas em presunções não enunciadas. A parede é nossa presunções"29.

Nestas intervenções urbanas (Figs. 7 a 10) o que se vê são diedros e triedros que sugerem a presença de um cubo branco que, ao tocar a superfície da cidade, promove seu apagamento, pequenas áreas limpas que contrastam com seu entorno urbano, carregado e poluído. No entanto, o cubo propriamente dito está ausente, e o que se percebe neste trabalho é o jogo entre sua virtualidade e seu registro físico. Além disso, o próprio cubo, como volume, joga com seu vazio potencial, conforme explica Didi-Huberman:

O que é um cubo? Um objeto quase mágico, com efeito. Um objeto a fornecer imagens, da maneira mais inesperada e mais rigorosa que existe. Certamente em razão de nada imitar antes dele, de ser para si mesmo sua própria razão figural. Ele é, portanto, um instrumento eminente de figurabilidade. ${ }^{30}$

Estes planos brancos na cidade vazam a paisagem ao mesmo tempo em que delimitam um espaço. Como se ao retirar este cubo que fizesse parte do urbano fosse possível ver a parede da galeria intacta sobre a qual se pendurou este cenário no qual vivemos. Há aqui uma conexão entre espaços não contíguos, o espaço externo da rua com o interno da galeria, o espaço habitado da cidade com o vazio do cubo branco.

\footnotetext{
O'DOHERTY, Brian. No Interior do Cubo Branco. São Paulo: Martins Fontes, 2002. p.4.

Idem. Ibidem. p.04.

Idem. Ibidem. p.102.

Idem. Ibidem. p.90.

DIDI-HUBERMAN, Georges. O que vemos, o que nos olha. São Paulo: Editora 34, 1998. p.88.
} 
Já nos trabalhos executados sobre móveis (Figs. 16 a 21), a materialidade do cubo branco ${ }^{31}$ é inserida diretamente nos espaços internos do mobiliário doméstico. Considero o interior das gavetas e armários como os espaços mais íntimos e reservados que uma pessoa pode possuir, onde se acumulam objetos e referências pessoais, assim como o filósofo e poeta francês Gaston Bachelard (1884-1962) define:

O armário e suas prateleiras, a escrivaninha e suas gavetas, o cofre e seu fundo falso são verdadeiros órgãos da vida psicológica secreta. Sem esses "objetos" e alguns outros igualmente valorizados, nossa vida íntima não teria um modelo de intimidade. São objetos mistos, objetos-sujeitos. Têm, como nós, por nós e para nós, uma intimidade. ${ }^{32}$

Desta forma, o ato de aplicar massa corrida e tinta nestes interiores cobre e acaba por aniquilar qualquer imagem e lembrança íntima do que neles esteve resguardado para receber o vazio explícito do cubo branco e as presunções nele contidas.

Em Cantos (Figs. 11 a 15), a cesura é buscada pelo simples ato de focar a atenção em um ponto onde os artefatos que remetem à vida cotidiana não podem alcançar. Estes trabalhos se baseiam em fotografias dos cantos formados pelas paredes com o teto de diversos espaços cotidianos diferentes - apesar de se apresentarem quase que idênticos —, nas quais o recorte próprio da fotografia permitiu que os indícios da vivência nesses espaços - quartos, corredores, salas de estar, etc. — não se fizessem presentes na imagem. Cada trabalho consiste em dois painéis fotográficos independentes, cada um apresentando uma imagem de cantos distintos que, combinados, formam um terceiro espaço: um espaço que só existe na justaposição destas imagens, onde é possível identificar as faces internas de um volume branco e neutro que parece estar hermeticamente fechado e sem relação alguma com o espaço do dia a dia. O resultado alcançado é a ilusão criada por imagens do próprio cotidiano que, ao se somarem, se anulam produzindo este espaço vazio, puro e protegido, sem qualquer conotação ao cotidiano.

\footnotetext{
${ }^{31}$ Apesar do título destes trabalhos ser Cubo Branco, os espaços criados nestes móveis não são necessariamente cubos, já que são referentes aos espaços físicos das galerias de arte, que raramente possuem a forma exata de cubos mas que são identificados como os cubos brancos mencionados por O'Doherty. Em nenhum momento o autor de No Interior do Cubo Branco menciona que os espaços das galerias às quais ele se refere por tal nome têm exatamente a proporção de cubos.
}

32 BACHELARD, Gaston. A Poética do Espaço. São Paulo: Martins Fontes, 2003. p.91. 
As pinturas que representam caixas abertas (Figs. 37 a 38) trabalham com a dialética do exterior e do interior, entendendo-a como o ser e o não-ser. Portanto, para se alcançar o negativo do mundo cotidiano deve-se explorar seu avesso. Se as faces externas de uma caixa fazem parte deste mundo comum, ao desmontá-la e olhar suas faces opostas, o que encontramos é um espaço branco, limpo e vazio, o que pode também ser chamado aqui de cesura.

Estas caixas revelam de maneira explícita seu interior vazio. Elas foram desmontadas e deixadas abertas da maneira como se posicionaram naturalmente, sem nenhuma tensão em suas dobras, em seu estado mais confortável, destituídas de suas funções originais. Apresentam-se como continentes de vazios, não só o de seu interior, mas principalmente de seu exterior. A função de uma caixa de ocultar seu conteúdo foi subvertida: no lugar de seu conteúdo original está sua ausência e esta não está de forma alguma resguardada, e sim, apresentada o mais diretamente possível, ao passo que se oculta sua parte externa. A inquietude que esta primeira ausência pode produzir é alimentada pela percepção de algo que está lá e que não pode ser visto. Estas são, no caso, as informações da face externa que remeteriam diretamente ao conteúdo que esta deveria ocultar. A face externa da caixa, que separa e encerra o conteúdo em seu interior e ao mesmo tempo o conecta e o anuncia ao mundo exterior através de sua superfície impressa, é ocultada nessas pinturas, de maneira que suas características são apenas indicadas pelo sangramento das cores usadas na impressão dos gráficos na aba de colagem da caixa.

Há uma perda de referência e definição dos objetos envolvidos nestes trabalhos em relação ao mundo cotidiano. Mesmo que as sobras do design gráfico da embalagem possam sugerir ao observador mais atento que estes produtos sejam remédios, molho de tabasco, sabonetes, etc., não é possível realmente defini-los. O objeto ausente fica numa situação de quase completo desaparecimento, e a cor sangrada faz o papel do tênue fio que não deixa o carretel desaparecer de vez. 


\section{O Exemplo de Morandi}

Encontro minha principal referência no trabalho do artista italiano Giorgio Morandi (1890-1964). As pinturas de Morandi se apresentam ordenadas, tranquilas e sem sobressaltos. Seu trabalho carrega esta qualidade de ser previsível, o que faz do conjunto de sua obra uma perfeita representação do conceito de cotidiano.

Segundo o relato da historiadora norte-americana Karen Wilkin, o artista trabalhava no mesmo pequeno e desordenado quarto durante toda sua vida, rodeado por um acúmulo de objetos humildes que davam origem às suas naturezasmortas a partir da "segurança não só no familiar e no cotidiano, mas também nos artistas do passado"33. Em seu ateliê, esses utensílios domésticos se tornavam resíduos de uma vida cotidiana esvaziados de suas funções usuais para se tornarem modelos.

Chama a atenção o fato de esse artista também trabalhar com um apagamento do cotidiano. Em sua pintura identificamos como característico um tom apagado e neutro. Morandi permitia que uma grossa camada de pó se acumulasse sobre seus modelos, o que ajudava a reduzir seus detalhes, tornando-os formas essenciais. Caixas e garrafas tinham suas etiquetas, marcas ou qualquer elemento identificador removidos. Além disso, muitos de seus objetos foram pintados de branco ou cinza para eliminar reflexos e as qualidades próprias dos objetos ${ }^{34}$.

Pela excessiva repetição de seus modelos, podemos entender que a escolha destes não se deu pela importância do objeto propriamente dito, mas, por ele não invocar interesse ou referências para si. Isso porque tais modelos poderiam ser compreendidos como elementos já conhecidos - como utensílios comuns à vida diária, em um primeiro momento, e como tema da pintura, num segundo momento não agregando às obras qualquer questão intrínseca à sua natureza, mas, pelo contrário, funcionando como um mero modelo para composições, estudos plásticos e formais. Com esta atitude, o artista recolhe elementos de seu dia a dia e, através de sua indiferença perante as qualidades, funções e significados, promove um apagamento das relações destes objetos com o cotidiano para estudar as qualidades pictóricas da composição, relações de espaço e forma, cores, proporções

\footnotetext{
33 A autora se refere aos artistas que Morandi admirava: Giotto, Piero e Cézanne. WILKIN, Karen. Morandi, Barcelona: Ediciones Polígrafa, 1998. p.94. Tradução minha.

34 WILKIN, Karen. Morandi, Barcelona: Ediciones Polígrafa, 1998. p.106. Tradução minha.
} 
e equilíbrio, na tentativa de transformar esta vida doméstica e diária em algo sublime.

Ao refletir sobre o processo de criação dos Quadros Pretos (Figs. 1 a 6), encontro uma postura similar em relação aos objetos eleitos para se tornarem modelos para pintura. Há, nestes trabalhos, uma intenção de reapresentar elementos familiares do dia a dia e esvaziá-los de sua função para reapresentá-los de uma maneira grandiosa. Encontro respaldo quando, citando 0 vagabundo criado por Charles Chaplin e seus frequentes duelos com os objetos comuns, Henri

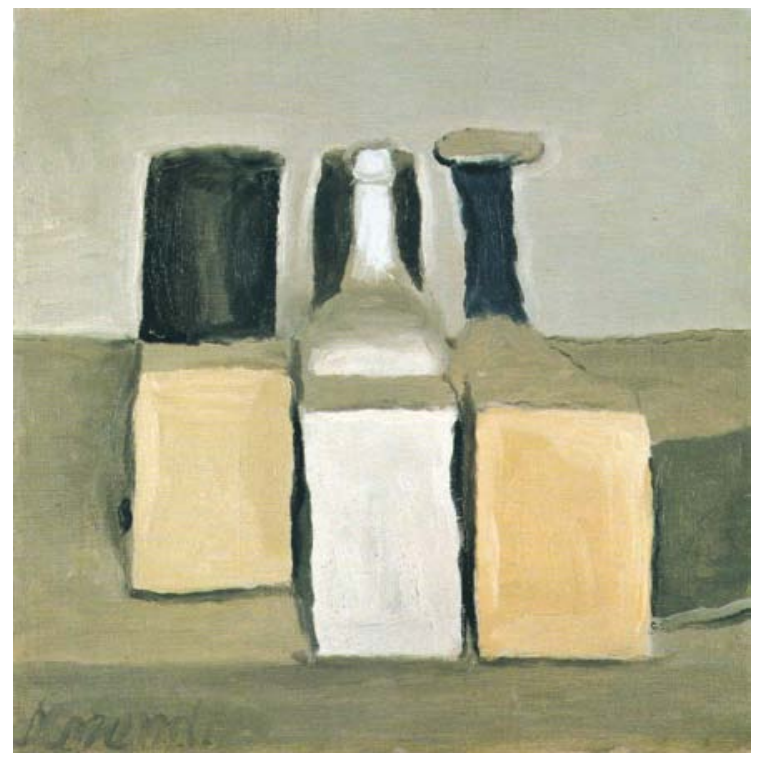

Giorgio Morandi Natureza-Morta, 1956 óleo sobre tela, $35,8 \times 35,2 \mathrm{~cm}$ Lefebvre nos mostra que "uma imagem profundamente enraizada no cotidiano pode ser vista como algo fabuloso" ${ }^{35}$. Por este ângulo, as coisas mais extraordinárias podem ser as mais cotidianas, e as coisas mais estranhas podem ser as mais triviais. No entanto, continua o autor, uma vez que imagens triviais estejam separadas de seu contexto, torna-se muito difícil de articulá-las de uma maneira que mostre sua qualidade cotidiana essencial ${ }^{36}$.

Paradoxalmente, apesar do esforço de Morandi em tratar estes objetos cotidianos como meros modelos abstratos, "a amplitude de sua inventividade como manipulador de cores e tons se faz mais visível que as limitações que ele mesmo se impõe e triunfa expressivamente com sua habilidade em evocar infinitas gamas de luz, horas do dia e mudanças de humor, aplicando matizes primorosamente ajustadas, apagadas e anônimas" ${ }^{37}$, impregnando novamente o trabalho com estes elementos do cotidiano.

Dentre todas as qualidades da pintura de Morandi, a que mais me chama a atenção é a representação dos espaços vagos nas composições. No embate entre figura e fundo característico de seu trabalho, o vazio é apresentado tão denso

\footnotetext{
35 LEFEBVRE, Henri. Critique of Everyday Life I - Introduction. London: Verso, 2008. p.13. Tradução minha.

${ }_{36}$ Idem. Ibidem. p.14.

37 WILKIN, Karen. Morandi, Barcelona: Ediciones Polígrafa, 1998. p.14. Tradução minha. 
quanto os objetos, e muitas vezes as formas que surgem entre as garrafas e caixas parecem ser o tema da composição.

De maneira similar, os Quadros Pretos também lidam com a questão da figura e fundo, matéria e vazio - porém, de uma maneira bem mais simplista, já que o vidro dos objetos retratados se torna invisível, naturalmente se confundindo com o fundo preto - de forma que o corpo dos potes só é percebido graças ao reflexo do ambiente circundante. Desta maneira a repetição do tema, com variações pequenas de composição, acaba por dar ênfase às mudanças das situações refletidas pelo vidro, sugerindo a noção de tempo.

Não são apenas as naturezas-mortas de Morandi que carregam esta interessante relação entre os conceitos de cotidiano e vazio. Na paisagem Patio en Via Fondazza, o céu, as edificações e a vegetação são representadas como planos e manchas de qualidades pictóricas, dialogando entre si por diferenças de cor, tons e formas. A empena em primeiro plano, por sua proximidade ao observador, acaba por encobrir

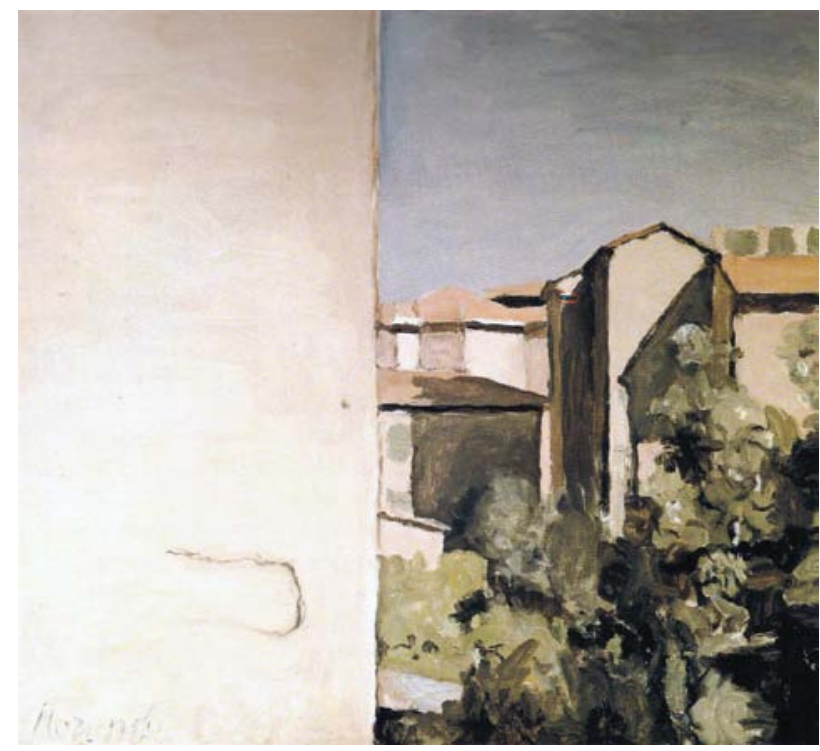

Giorgio Morandi Patio en Via Fondazza, 1954 óleo sobre tela, $49 \times 54 \mathrm{~cm}$ grande parte da paisagem, criando um estranhamento na composição. Interpreto esta empena como uma cesura, uma tentativa de criar uma interrupção na paisagem cotidiana. Encontro nesta obra, portanto, um interessante referencial para o conceito que permeia todo o meu trabalho, a representação do cotidiano e seu subsequente esvaziamento através de recortes ou a adição de matéria. Por exemplo, a inserção de um fragmento de parede - que poderia muito bem ser da mesma matéria da empena de Patio en Via Fondazza - para ocultar as informações da vida diária (Figs 25 a 28). 


\section{Questões da Imagem}

No decorrer do desenvolvimento do trabalho artístico, ao analisar as diferentes formas sob as quais as obras plásticas se apresentavam - muitas vezes bastante contrastantes entre si - , apresentando claramente fases distintas, diferentes técnicas e meios, deparava-me constantemente com a dúvida em relação à consistência dessa produção. A constante ruptura com um processo específico para adoção de outro em um trabalho seguinte não permitia a constituição de um conjunto de obras homogêneo, o que dificultava a compreensão de sua coerência. Parecia-me ir contra os exemplos dos artistas os quais admirava e que apresentavam um desenvolvimento paulatino de sua técnica sem quebras formais constantes e bruscas, criando um estilo próprio e facilmente reconhecível.

Só depois de algum tempo, quando já havia acumulado um número suficiente de obras, fases e exposições, foi possível ter um olhar mais abrangente, relacionando os diferentes meios utilizados. Tornou-se claro que os diferentes momentos no desenvolvimento do trabalho lidam com os mesmos conceitos de cotidiano e vazio - tema de toda a pesquisa - e que colaboram com grande importância, cada qual à sua maneira particular, para o desenvolvimento e aprofundamento do trabalho.

Sendo assim, a preocupação em relação à consolidação de um estilo baseado em fatores formais se mostrou sem importância. Ao discorrer sobre estilo como sendo um dos conceitos para a definição da obra de arte - junto da retórica e expressão -, Danto aproveita-se das ideias do escritor francês Conde de Buffon (1707-1788) ao estabelecer que "o estilo é o próprio homem", já que estilo é "esse modo de uma pessoa representar o que quer que ela represente"38.

A estrutura de um estilo é como a estrutura de uma personalidade, e aprender a reconhecer um estilo é mais que um mero exercício taxonômico: é como aprender a reconhecer o jeito de uma pessoa ou seu caráter. Atribuir uma obra a uma pessoa é tão complexo quanto atribuir um ato a alguém sem ter certeza de quem o praticou. Temos de nos perguntar se esse ato é coerente com o caráter da pessoa, assim como temos de nos perguntar se o trabalho é coerente com o conjunto de uma obra. Esse conceito de coerência tem pouco a ver com coerência formal. ${ }^{39}$

38 DANTO, Arthur. A Transfiguração do Lugar-comum. São Paulo: Cosac Naify, 2005. p.293.

Idem. Ibidem. p.296 
Portanto, a diversidade de resultados formais, os diferentes tipos de linguagens e imagens criadas constituem uma característica de meu trabalho e merecem uma maior investigação.

Apesar de ter maior interesse pela técnica da pintura, durante 0 desenvolvimento dos trabalhos me deparei com a sensação de que determinada obra deveria ser desenvolvida exclusivamente em determinado meio. Esta noção intuitiva foi posta à prova diversas vezes. Alguns trabalhos que tiveram sua materialização final em fotografia, por exemplo, foram inicialmente experimentados em pintura, porém não alcançaram, nesse primeiro momento, resultados satisfatórios. Assim como outros projetos, que tiveram seus primeiros estudos em fotografia e se desenvolveram em pinturas. Ou, então, desenhos que, apesar de parecerem obras finalizadas, pediam algo mais e se tornaram objetos.

Neste momento da reflexão sobre minha obra, as questões referentes à imagem apresentam grande relevância, já que se torna pertinente o questionamento da razão desta variedade de processos para formação de imagem presente em meu trabalho para explorar um único tema.

O cotidiano aparece retratado na forma de espaços comuns e íntimos, objetos, móveis e outros elementos que remetam a uma rotina corriqueira e facilmente reconhecível. A imagem tem inicialmente a função de trazer esta "coleção de objetos fúteis, indignos de entrarem nos domínios da Física, do Divino, do Humano profundo"40 como signo icônico de uma realidade já conhecida pelo observador. A reapresentação do mundo trivial ao observador poderia ser entendida como apenas mais uma repetição natural do cotidiano, já que segundo Lefebvre, este se compõe de repetições ${ }^{41}$.

O conjunto da obra apresenta imagens que representam seu objeto de diversas maneiras. As diferentes relações entre imagem e seu referente, e os variados graus de realidade que as imagens carregam em sua superfície visam criar estímulos no observador que pendem entre uma realidade objetiva e uma paisagem vaga, repleta de brechas.

Além disso, a maneira como o meio é trabalhado, criando esta diversidade de resultados formais, acaba por criar uma variação em sua opacidade. "Para que a

\footnotetext{
40 LEFEBVRE, Henri. A Vida Quotidiana no Mundo Moderno. Lisboa: Ulisseia, 1969. p.25.

41 Idem. Ibidem. p.31.
} 
ilusão ocorra, o observador não pode ter consciência das propriedades que pertencem aos meios usados para produzi-la" ${ }^{42}$. Portanto, encontramos aqui trabalhos que se aproveitam da transparência do meio para criar maior ilusão como, por exemplo, as fotografias - e outros que abrem mão do trompe-l'oeil para dar maior ênfase à sua própria materialidade - como os desenhos. Apesar da diferente opacidade do meio de cada trabalho, todos eles carregam o conceito de expressão já que, além de serem representações, exprimem alguma coisa sobre o tema.

O que é expresso por esse meio é a retórica contida na obra de arte. "Retórica tem a função de induzir as pessoas a ver a matéria sob determinado ângulo" ${ }^{43}$. É interessante perceber que mesmo através de um meio objetivo, como a fotografia, pode existir uma retórica, como no exemplo dado por Danto, no qual ele diz que "mesmo no texto mais objetivo a retórica pode ser inevitável, e é possível que o próprio uso de um estilo de escrita objetivo seja retórico, no sentido de assegurar ao leitor que ali só há fatos, os quais falam por si” ${ }^{44}$.

Ao descrever a metáfora - e caracterizá-la como uma pequena obra de arte - como uma das formas de retórica possível, Danto nos mostra que as obras de arte, através de uma maior opacidade do meio, "apresenta seu objeto e ao mesmo tempo a maneira como o apresenta. Elas não meramente representam objetos; as propriedades do modo de representação devem fazer parte de sua compreensão" ${ }^{45}$.

Dentre os principais processos para formação de imagem presentes em minha obra foi possível identificar o uso do Índice, Fotografia, Pintura Fotorrealista e a Imagem-objeto.

Índice

Segundo o filósofo norte-americano Charles Pierce (1839-1914), "um índice é um signo que se refere ao objeto que denota em virtude de ser realmente afetado por esse objeto. (...) Na medida em que o índice é afetado pelo objeto, tem ele necessariamente alguma qualidade em comum com o objeto, e é com respeito a estas qualidades que ele se refere ao objeto" ${ }^{46}$. Em outras palavras, o índice está

\footnotetext{
DANTO, Arthur. A Transfiguração do Lugar-comum. São Paulo: Cosac Naify, 2005. p.224.

Idem. Ibidem. p.244.

4 Idem. Ibidem. p.245.

5 Idem. Ibidem. p.273.

46 PIERCE, Charles Sanders. Semiótica. São Paulo: Editora Perspectiva, 1977. p. 52.
} 
ligado ao real, dinamicamente conectado ao seu objeto, e indicando objetos dos quais estes signos são partes. Portanto, os índices acabam por se apresentar na "forma de vestígios, marcas ou traços" 47 .

Espaços (Figs. 22 a 24) são desenhos feitos com lápis grafite sobre papel que apresentam perspectivas de espaços genéricos. Mas, de maneira inversa ao modo convencional de desenhar, as linhas que definem os desenhos são as únicas áreas deixadas vazias pelos traços do lápis grafite, sendo que o restante da superfície das 98 folhas de papel A3 que formam cada um dos desenhos é preenchido pelo rabiscar do lápis.

Os traços de grafite estão em evidência e são o resultado da ação do rabiscar sobre a superfície da obra e, portanto, acabam por funcionar como índice desta ação. Por estar diretamente ligado ao real - neste caso a atividade de rabiscar - é através deste índice que o observador tem a indicação do momento do trabalho, do processo, do longo tempo, da repetição e esforço envolvidos para a representação destas perspectivas. Sendo assim, visto sob o conceito de índice, a superfície desta imagem apresenta um espaço vazio e genérico, mas também carrega matéria, tempo e ação.

Estas obras baseiam-se na ideia de trabalhar o paradoxo do pleno para representar o vazio, sendo que, a atividade de rabiscar, sua repetição e longa duração, apresentada ao observador através do índice dos traços de grafite, remetem às características do cotidiano.

Como vimos anteriormente, os trabalhos Amplificadores (Figs. 34 a 36) também se beneficiam desta técnica e do uso do índice para alcançar o efeito pretendido na materialização destas obras.

\section{Fotografia}

Em sua análise sobre a fotografia, o filósofo francês Roland Barthes (19151980) questiona-se: "A fotografia ultrapassa realmente a si própria: não será essa a única prova de sua arte? Anular-se como medium, deixar de ser um signo, passando a ser a própria coisa?" ${ }^{48}$. Esta é a qualidade máxima da fotografia, o que a torna

\footnotetext{
47 SANTAELLA, Lucia. Semiótica Aplicada. São Paulo: Thomson, 2005. p. 36.

48 BARTHES, Roland. A Câmara Clara. Lisboa: Edições 70, 2005. p.71.
} 
transparente, dando-nos a ilusão de estar observando a própria realidade e não uma mera imagem.

Barthes justifica este fato exclamando que "a foto é literalmente uma emanação do referente" ${ }^{49}$, referindo-se claramente às características físicas e químicas do processo fotográfico que permite que os raios luminosos refletidos por um objeto sejam captados e fixados na superfície da fotografia que por sua vez chegam ao olhar do observador. Por isso a fotografia está diretamente conectada ao real $^{50}$. Ao analisar uma antiga fotografia, Barthes se depara com:

Nada de extraordinário, a não ser esta coisa, que nenhuma pintura realista poderia dar-me: a certeza de que eles estavam lá; aquilo que vejo não é uma recordação, uma imaginação, uma reconstituição (...), mas o real no estado passado: simultaneamente o passado e o real. ${ }^{51}$

Apesar de afirmar que "a aparente objetividade das imagens técnicas é ilusória, pois na realidade são tão simbólicas quanto o são todas as imagens" ${ }^{\text {"2 }}$, o filósofo tcheco Vilém Flusser (1920-1991) reforça a ideia de verdade que estas imagens têm sobre o observador:

O caráter aparente não-simbólico, objetivo e sem mediação das imagens técnicas faz com que seu observador as olhe como se fossem janelas e não imagens. O observador confia nas imagens técnicas tanto quanto confia em seus próprios olhos. ${ }^{53}$

A fotografia carrega a realidade à obra. Os trabalhos realizados em fotografia têm a intenção de trazer esta realidade sem qualquer manipulação para ser exposta diretamente ao observador. Portanto, a ideia, ao usar este meio, é apresentar os elementos do mundo trivial como se não houvesse nenhuma mediação, são lacunas brancas já existentes no cotidiano e, neste caso, o papel do artista foi apenas de procurá-las, identificá-las, registrá-las e apresentá-las.

O trabalho tem como ponto fundamental o fato de tal objeto existir, como se fosse realmente o registro objetivo de uma descoberta. Por isso, ele não poderia ter sido executado em nenhum outro meio. Uma pintura ou um desenho poderiam muito

\footnotetext{
Idem. Ibidem. p.114.

Sendo assim, pode-se classificar a fotografia como um Índice.

1 BARTHES, Roland. A Câmara Clara. Lisboa: Edições 70, 2005. p.117.

52 FLUSSER, Vilém. Filosofia da Caixa Preta: Ensaios para uma futura filosofia da fotografia. Rio de Janeiro: Relume Dumará, 2002. p.14.

53 Idem. Ibidem. p.14
} 
bem simular sua existência sem nunca ter existido e por mais realista que fossem nunca trariam a sensação de verdadeiro que uma fotografia carrega.

Para aumentar ainda mais a ilusão de realidade da fotografia, as imagens dos trabalhos da série Pinturas (Figs. 30 a 32) foram feitas em filme de médio formato e ampliadas em tamanho natural em ótima qualidade, de modo que fosse possível ver todos os detalhes da superfície da parede fotografada com perfeição. As fotografias foram montadas em painéis de alumínio sem vidro ou moldura de modo que as imagens se mesclassem com o espaço físico onde estariam expostas.

Estas imagens mostram marcas deixadas na parede, indícios da existência de um objeto que lá esteve pendurado por longo tempo. Não é possível determinar se eram de fato pinturas, ou se eram fotografias, pôsteres, espelhos, etc. Mas me aproveito deste jogo entre imagem e texto para sugerir que esse objeto ausente poderia ser uma pintura, ao mesmo tempo em que proponho uma interpretação de que estas marcas na superfície poderiam ser entendidas como pintura propriamente dita, se aproximando da descrição feita pelo autor clássico Plínio, o Velho (23 d.C.79 d.C.) sobre as origens incertas da pintura, na qual chega à conclusão de que seu surgimento se deu ao "circunscrever com linhas o contorno da sombra de um homem" 54 .

\section{Pintura Fotorrealista}

Ao lidar com os conceitos de vazio e cotidiano, propondo um esvaziamento do real, encontro nas pinturas em técnica fotorrealista (Figs. 1 a 6, 29, 33 e 37 a 39) um interessante meio para aprofundar estas questões.

Ao comparar pinturas fotorrealistas com pinturas miméticas desenvolvidas de maneira tradicional, ou seja, o artista tendo à sua frente o modelo para sua representação, é possível notar que esses dois tipos de pintura têm naturezas e qualidades bastante distintas. Restringindo esta reflexão às questões referentes à imagem, pode-se dizer que esta diferença se deve ao fato de que a adoção da fotografia como intermédio entre o artista e seu modelo para representação do tridimensional em bidimensional, traz consigo toda uma gama de símbolos e códigos inerentes à imagem fotográfica. No entanto, carregada, até certo ponto, com os

54 PLINIUS SECUNDUS, Caius. Textos de Historia del Arte. Madrid: Visor, 1988. p.78. Tradução minha. 
elementos da imagem técnica, a pintura fotorrealista se reafirma como pintura através de suas características próprias.

Estas pinturas são desenvolvidas a partir de estudos fotográficos. No processo de tradução desses estudos em pintura há uma perda da objetividade e do aspecto de verdadeiro da imagem original, mas ao mesmo tempo certas características simbólicas da imagem fotográfica permanecem como, por exemplo, a perspectiva deformada, a luz chapada do flash, objetos desfocados, etc. Portanto, mesmo que a imagem pictórica deixe aparente a mediação do artista, existe ainda um resíduo da objetividade e proximidade da fotografia.

Pode-se dizer que o meio transparente da fotografia se tornou mais turvo. A ilusão ainda existe, no entanto é falha, já que a pintura deixa em evidência não só seu próprio meio, mas também o meio da fotografia. A imagem fica entre uma descrição objetiva e uma descrição pictórica da realidade. É possível identificar traços de certeza e fidelidade entre elementos pictóricos e vagos.

O trabalho When routine bites hard (Fig. 33) retrata um frame retirado do conhecido videoclipe Love will tear us apart, da banda inglesa pós-punk Joy Division, e se apresenta como uma experiência que vai além dos objetivos da pesquisa fotorrealista.

Esta imagem foi escolhida para desenvolver o trabalho devido à referência direta da letra da música - cujo primeiro verso dá título à obra - ao cotidiano, combinado ao interesse pelo espaço físico que serviu de locação para a filmagem um grande espaço industrial vazio - e a representação da imagem televisionada, uma mídia muito presente no dia a dia. A cesura foi provocada de maneira simples e direta, através do estado de pausa que a pintura conferiu ao videoclipe, suspendendo permanentemente a reprodução da música.

Ao contrário das outras pinturas, a imagem técnica, neste caso, não foi feita para funcionar como um estudo para a execução da pintura; mas foi coletada dos meios de circulação para servir como modelo para este trabalho. Portanto, nesta obra os diferentes níveis de interpretação da imagem em relação ao seu objeto estão mais evidentes. Podemos entender como referente o próprio videoclipe ou então o espaço físico captado pelo cinegrafista. 
O filósofo alemão Walter Benjamin (1892-1940) faz uma comparação entre os dois tipos de produtores de imagens envolvidos nesta obra, o pintor e o cinegrafista.

O pintor observa em seu trabalho uma distância natural entre a realidade dada e ele próprio, ao passo que o cinegrafista penetra profundamente as vísceras dessa realidade. As imagens que cada um produz são, por isso, essencialmente diferentes. A imagem do pintor é total, a do operador é composta de inúmeros fragmentos, que se recompõe segundo novas leis. ${ }^{55}$

É nessa meia-distância, entre o posicionamento do pintor e do cinegrafista, que me coloco ao executar esta obra. Assim como as demais pinturas aqui apresentadas, esta pintura se aproveita das qualidades ímpares da imagem resultante da técnica da pintura fotorrealista para agregar sentido à obra. Sua compreensão é inseparável do modo de representação.

\section{$\underline{\text { Imagem-objeto }}$}

$\mathrm{Na}$ experiência de representar os elementos do cotidiano utilizando técnicas que carreguem maior ou menor grau de realidade nas superfícies das imagens produzidas, acabo por lançar diretamente à obra os próprios elementos retirados do mundo comum.

A série de desenhos de massa corrida e tinta acrílica sobre papel pautado (Figs. 25 a 28) são representações que carregam elementos retirados do próprio real para explorar paradoxos presentes em meu trabalho, como o excesso - de técnica, matéria, trabalho, etc. - para representar o vazio e/ou o vazio (ou o quase nada) para sugerir o pleno. Estas obras são formadas pela superfície da parede que apaga compromissos e anotações do dia a dia, que são mencionados nos títulos dos trabalhos, trazendo o paradoxal processo de se adicionar matéria para apagar referências ou significados de nosso cotidiano, dando sentido à obra, criando o vazio que se apresenta como a plenitude de possibilidades.

A combinação de objetos imiscíveis de funções e universos diferentes - a folha pertence ao universo das ideias, a massa corrida ao universo material, espacial - e o suposto apagamento de informações do caderno deixa evidente a possibilidade de uma interpretação. "Dado ao caráter constitutivo da interpretação, o

55 BENJAMIN, Walter. Magia e Técnica, Arte e Política: Ensaios sobre Literatura e História da Cultura. São Paulo: Editora Brasiliense, 1996. p.186. 
objeto não era obra de arte antes de ser interpretado. Na qualidade de um processo de transformação, a interpretação é algo como um batismo, não por dar um nome ao objeto, mas por emprestar-lhe uma nova identidade e fazê-lo ingressar na comunidade dos eleitos" ${ }^{56}$.

Pode-se dizer que estes trabalhos apresentam um parentesco com as colagens cubistas, já que os artistas cubistas, com suas colagens do início do século 20, criaram uma forma inédita de representação pictórica, colando no quadro fragmentos do real e, desta forma, abrindo caminho para uma arte que compartilha o mundo real, apresentando o real e não mais o representando. $O$ teórico francês Edmond Couchot faz uma análise sobre as colagens cubistas:

Como se o próprio real se projetasse no plano do quadro para nele esmagar-se; como se tendesse a incorporar-se ou substituir-se à imagem, a inscrever, da maneira mais direta possível, sua própria materialidade na tela, sem mediação de qualquer emanação luminosa organizada. Como se tratasse de apresentar o real e não mais de representá-lo. (...) A Representação cedia lugar, no domínio da arte (o da imagem não automática), à presentação. ${ }^{57}$

Sendo assim, nestes trabalhos a relação objeto - imagem - sujeito continua inalterada. No entanto, a distância entre objeto e imagem é abolida. O objeto não mais simplesmente preexiste à imagem, mas coexiste com ela.

6 DANTO, Arthur. A Transfiguração do Lugar-comum. São Paulo: Cosac Naify, 2005. p.190.

57 COUCHOT, Edmond. Da Representação à Simulação, in: PARENTE, André. Imagem Máquina - A Era das Tecnologias do Virtual. São Paulo: Editora 34, 1993. p.44. 


\section{Arte, vida e ausência}

Tendo em vista que o trabalho plástico aqui apresentado parte da representação da vida cotidiana, seus espaços e elementos, lidando com sua realidade e compartilhando seu espaço comum, torna-se interessante lançar um olhar sobre a História da Arte para identificar e entender quais as origens destas qualidades que o trabalho carrega. Sendo assim, o texto foca neste momento um ponto de mudança radical no rumo da Arte, no qual, após seguir a evolução das Vanguardas Modernistas, distanciando-se cada vez mais do compromisso com a representação da vida e do real, os artistas - a partir da Arte Pop — voltam novamente a buscar em seu espaço cotidiano os elementos para criação. Este interesse pela realidade, no entanto, não significou simplesmente voltar a representar mimeticamente o mundo como foi pintado pelos grandes mestres, mas sim uma tentativa de quebrar as barreiras entre arte e vida.

Porém, a vida cotidiana na qual estamos inseridos é drasticamente diferente daquela do passado, já que percebemos e nos relacionamos com nossa realidade indiretamente através de imagens. Representar estas imagens acaba por amplificar a ausência do objeto real. Neste caso, a arte se relaciona com a vida através de uma ausência.

\section{A Pintura da Ausência}

Segundo Arthur Danto um dos sentidos de representação é "algo que está no lugar de outra coisa" ${ }^{58}$ em uma relação entre aparência e realidade. Por esta razão, toda pintura que tem um compromisso com um mimetismo lida com uma ausência inerente a sua natureza. Neste sentido, não há uma pintura a qual não apresente a ausência do objeto representado.

No entanto, a presença cada vez maior das imagens técnicas no cotidiano através da massificação dos meios de comunicação causou uma profunda mudança na sociedade e na maneira como o homem se relaciona com sua realidade. A própria evolução da arte pode nos mostrar claramente que a realidade vivida no mundo cotidiano mudou drasticamente. As obras de arte deixaram de representar o real, os objetos do mundo, para representar os signos do real. Esta mudança pode ser percebida através da arte desenvolvida a partir do final da década de 1950, a

58 DANTO, Arthur. A Transfiguração do Lugar-comum. São Paulo: Cosac Naify, 2005. p.56. 
Arte Pop, que tem como uma de suas características a produção de imagens a partir de imagens. A realidade passa a ser mediada através das imagens, segundo Flusser:

Imagens são mediações entre homem e mundo. O homem "existe", isto é, o mundo não Ihe é acessível imediatamente. Imagens têm o propósito de representar o mundo. Mas, ao fazê-lo, interpõem-se entre o mundo e o homem. Seu propósito é serem mapas do mundo, mas passam a ser biombos. O homem, ao invés de se servir das imagens em função do mundo, passa a viver em função de imagens. Não mais decifra as cenas da imagem como significados do mundo, mas o próprio mundo vai sendo vivenciado como conjunto de cenas. ${ }^{59}$

As questões levantadas pela Arte Pop em relação à representação do simulacro criaram condições para o surgimento de uma nova postura por parte dos artistas. A pintura desenvolvida a partir de então baseou-se cada vez mais em representar a realidade a partir de suas representações fotográficas, entendendo que esta seria a melhor maneira de representar a realidade, uma vez que "tudo, atualmente, tende para as imagens técnicas, são elas a memória eterna de todo empenho. Todo ato científico, artístico e político visa a eternizar-se em imagem técnica, visa ser fotografado, filmado, videoteipado" ${ }^{60}$. Não se trata, portanto, de usar fotografias como um mero "aide-mémoire" ${ }^{61}$, como faziam os artistas desde o século 19, mas sim de explorar a relação entre imagem e realidade.

O artista alemão Gerhard Richter (1932) vem produzindo suas pinturas, desde o início da década de 1960, a partir de imagens retiradas de mídia impressa e fotografias feitas por ele mesmo, lidando de maneira muito consciente com as questões referentes à imagem na pintura contemporânea. Ele mesmo se apresenta como um pintor de imagens:

É muito melhor pintar um retrato a partir de uma fotografia, porque não estou pintando uma pessoa em particular, mas sim uma imagem que não tem nada de comum com o modelo. A similaridade com o modelo em uma

59 FLUSSER, Vilém. Filosofia da Caixa Preta: Ensaios para uma futura filosofia da fotografia. Rio de Janeiro: Relume Dumará, 2002. p.9.

60 Idem. Ibidem. p.18.

61 RUGOFF, Ralph. Painting Modern Life, in: CHRISTOV-BAKARGIEV, Carolyn; HERBERT, Martin; RUGOFF, Ralph; SCHWABSKY, Barry; SILVERMAN, Kaja. The Painting of Modern Life. Londres: Hayward Publishing, 2007. p.10. 
de minhas pinturas é, não só meramente aparente e não intencional, mas como completamente inútil. ${ }^{62}$

Entendemos então que, da mesma maneira que os artistas da Arte Pop americana, Richter está sempre pintando o mesmo tema. Seu objeto será sempre a imagem.

Acredito que o pintor não tem a necessidade de ver ou conhecer o modelo, não há um aspecto de alma do ser ou do caráter do modelo que requeira expressão. Um pintor não tem a necessidade de ver o modelo em uma maneira particular, pessoal, como um retrato não pode ser mais parecido com o modelo do que sua aparência. ${ }^{63}$

Aqui, Richter já aponta para uma perda em sua pintura. No retrato tradicional, pintar um tema a partir do real significa pintar não só uma figura, mas uma relação entre pintor e modelo. Os trabalhos de Richter, portanto, caracterizamse pela ausência desta relação. Não há mais a relação entre aparência e realidade.

Gerhard Richter

Galerie, 1967

óleo sobre tela, $30 \times 24 \mathrm{~cm}$

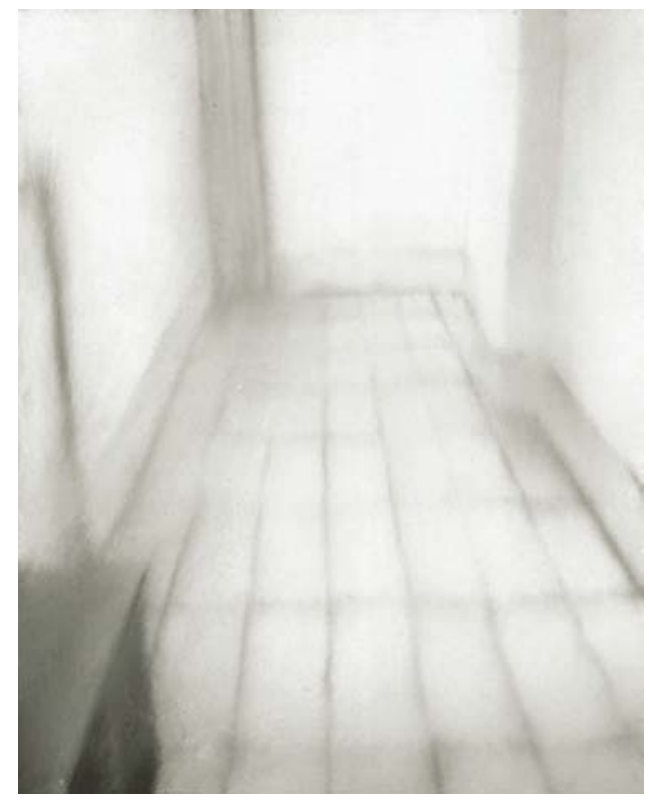

Da mesma forma, os pintores hiper-realistas surgidos nos últimos anos da década de 1960, como os americanos Richard Estes (1932), Chuck Close (1940) e Robert Bechtle (1932), por conta de sua preocupação excessiva com a ilusão reproduzindo com perfeição imagens fotográficas - apresentam de maneira explícita uma ausência da realidade - ausência não só do objeto retratado, mas do real - em suas representações. Segundo o crítico Hal Foster, este tipo pintura não

62 Entrevista concedida por Gerhard Richter. RAINBIRD, Sean. Gerhard Richter, Londres: Tate Gallery Publications, 1991. p.15. Tradução minha.

${ }_{63}$ Idem. Ibidem. p.15. 
lida apenas com a técnica do trompe-l'oeil, mas também se apresenta como evasiva em relação ao real, empenhada em "embalsamá-lo em aparências"64. O que é representado nestas pinturas é apenas a aparência do real, sem qualquer relação direta ao referente. Esta relação não é mais possível, o real é tratado como um elemento ausente antes mesmo de se iniciar a pintura, já que a imagem fotográfica que serve como modelo carrega em sua superfície "o poder assassino das imagens, assassinas do real" 65 .

Robert Bechtle Alameda Chrysler, 1981 óleo sobre tela, $122 \times 175 \mathrm{~cm}$

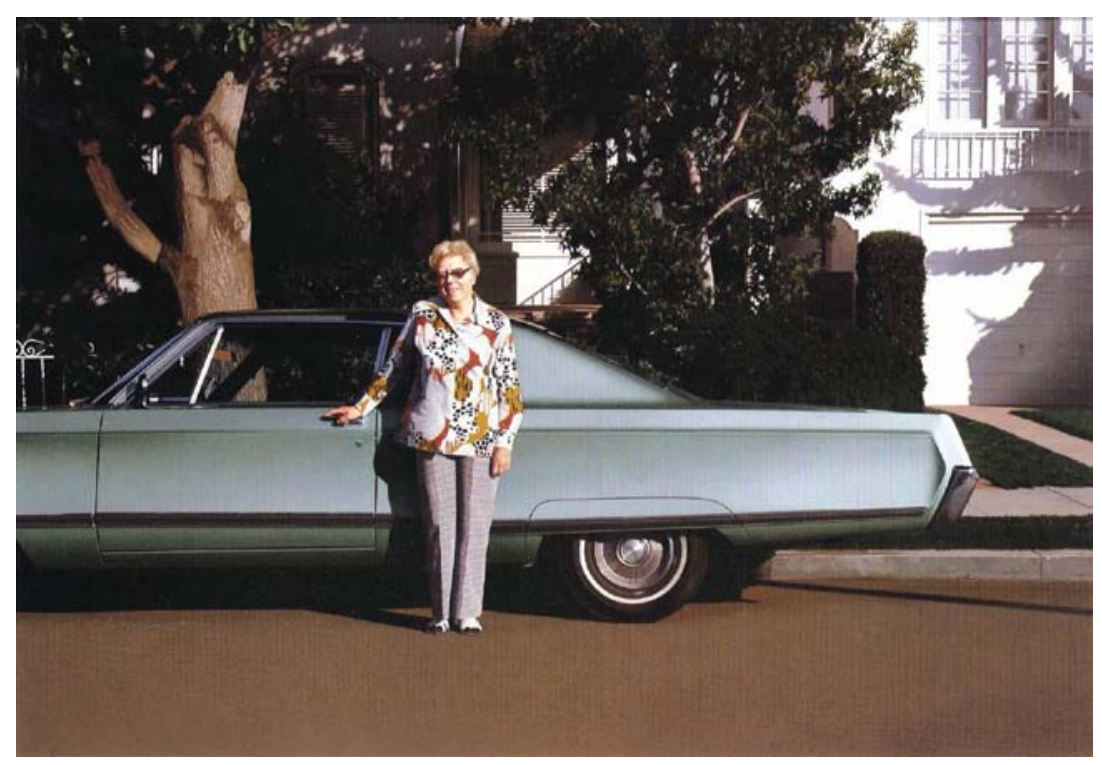

Ao observar estes trabalhos há uma estranha sensação de ver o real em seus mínimos detalhes. Porém, é impossível identificar esta imagem como sendo um recorte do mundo real. Nestas pinturas o real está ausente.

Já o artista belga Luc Tuymans (1958) é mais um pintor que comumente trabalha a partir de documentos fotográficos, aproveitando-se da herança dos artistas da Arte Pop. No entanto, não encontramos a idolatria exacerbada presente nos trabalhos destes. Ao contrário, aprofundando-se nas questões sobre o embate entre a imagem técnica e a imagem pictórica, Tuymans parece querer remover de suas imagens o caráter de verdadeiro que se atribui às fotografias da mídia.

Em suas pinturas é possível perceber uma tentativa de dissimular a presença de uma imagem preexistente. Trabalhando os elementos pictóricos da pintura, suprimindo detalhes e empalidecendo as cores, o artista esvazia a objetividade da imagem, apagando os elementos simbólicos da objetiva fotográfica, sugerindo uma tentativa de anular a mediação deste dispositivo entre o artista e a

64 FOSTER, Hal. The Return of the Real. Cambridge: MIT Press, 1996. p.141. Tradução minha.

65 BAUDRILLARD, Jean. Simulacros e Simulação. Lisboa: Relógio d'Água Editores, 1991. p.12. 
realidade. Tuymans constrói suas pinturas a partir da imagem fotográfica de maneira a criar uma representação falha - contrariando a natureza da imagem original - , criando uma pintura repleta de lacunas, permitindo que "a pintura funcione como um espelho: o que você vê vem de algum outro lugar" ${ }^{\prime 66}$.

O uso da imagem fotográfica como ponto de partida para a execução de pinturas não se restringe meramente, portanto, a um procedimento para solucionar o problema da tradução do tridimensional em bidimensional. Ela surge como uma ferramenta para amplificar a ausência presente na pintura.

A pintura não retrata mais o objeto ausente, mas agora representa a ausência do objeto ausente. Não há mais o referente; ele se perdeu antes mesmo de se preparar a tela. Não é possível mais misturar a tinta para alcançar a cor refletida pelo objeto; a cor que servirá de base para a pintura é uma cor simulada que não compartilha, de maneira nenhuma, da mesma pigmentação do objeto real. Esta pintura surge de uma lacuna, um vazio entre o artista e a realidade.

66 TUYMANS, Luc, Artist's Writings. in: ALIAGA, Juan Vicente; LOOCK, Ulrich; REUST, Hans Rudolf; SPECTOR, Nancy; TUYMANS, Luc. Luc Tuymans. Londres: Phaidon Press, 2003. p.140. Tradução minha. 


\section{Obras}

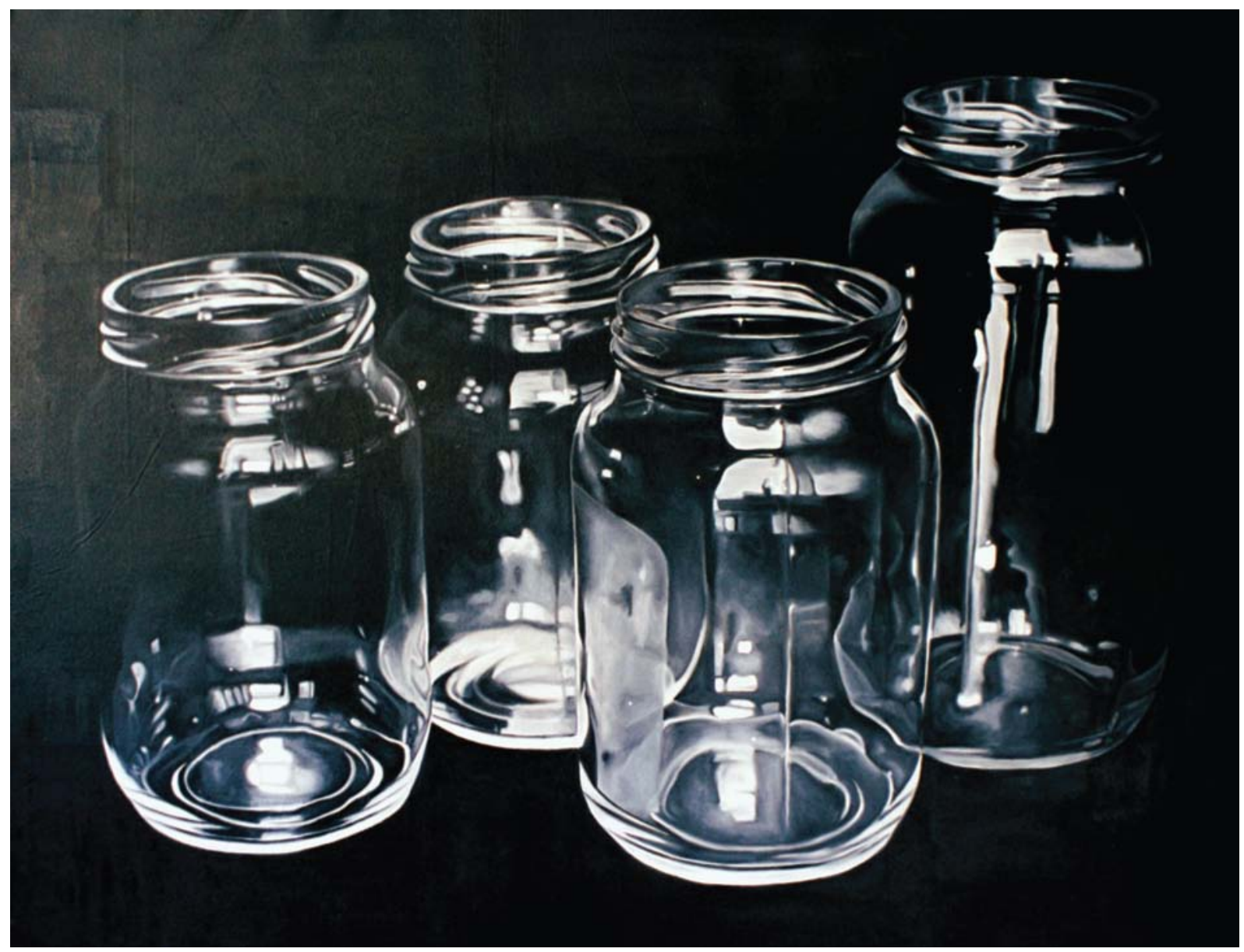

[1]

Quadro Preto, 1999

óleo sobre tela, $130 \times 173 \mathrm{~cm}$ 


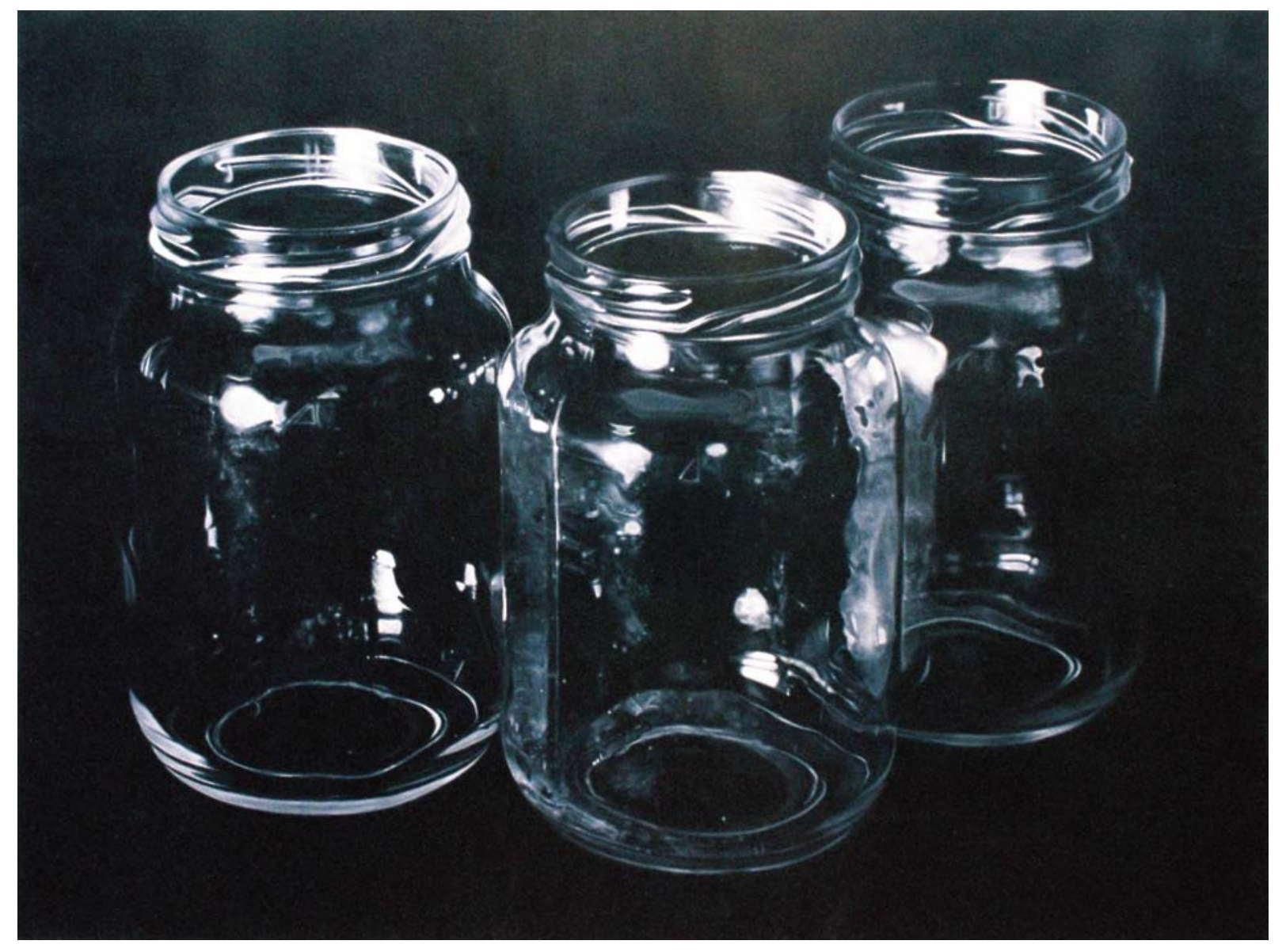




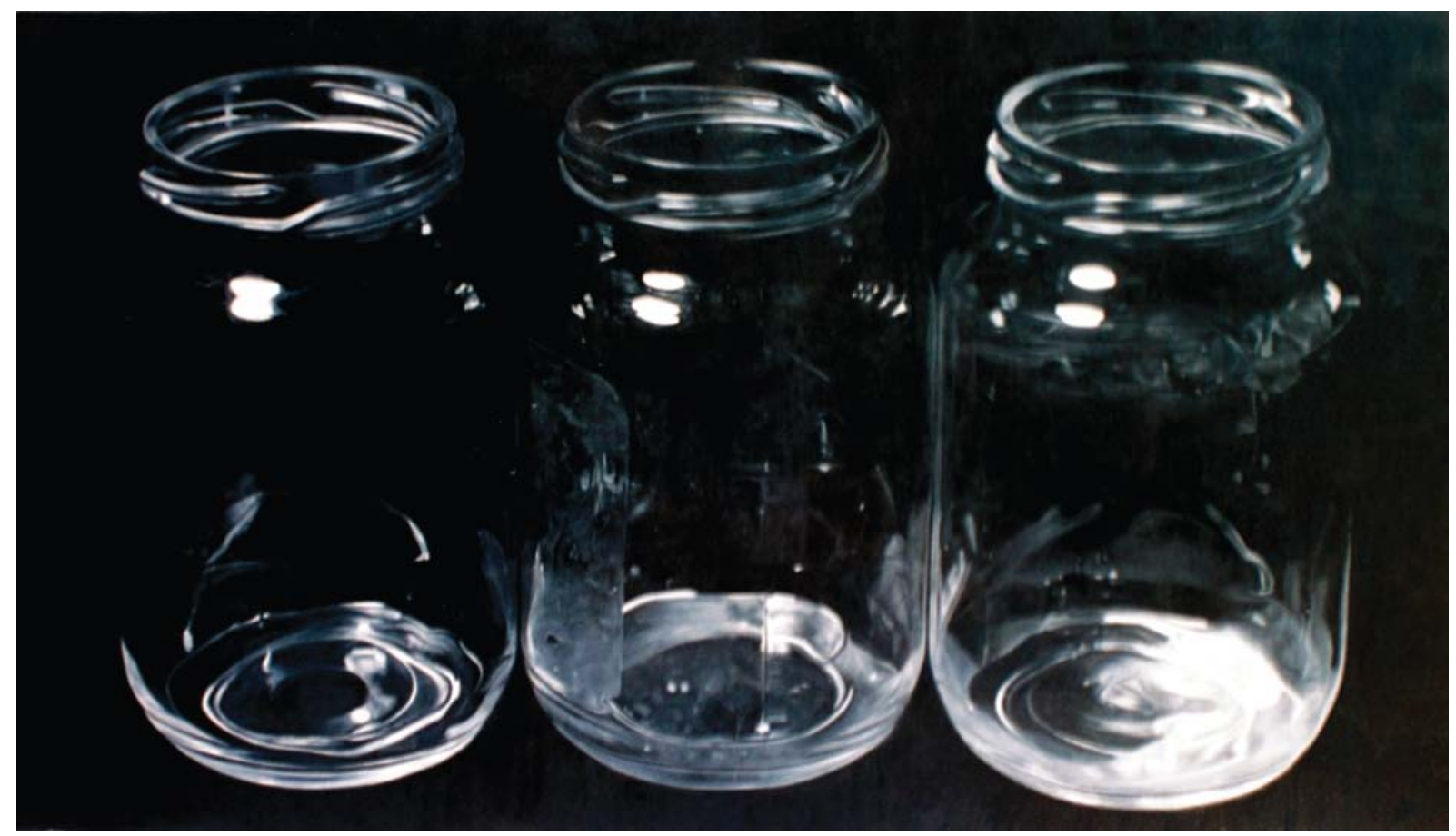




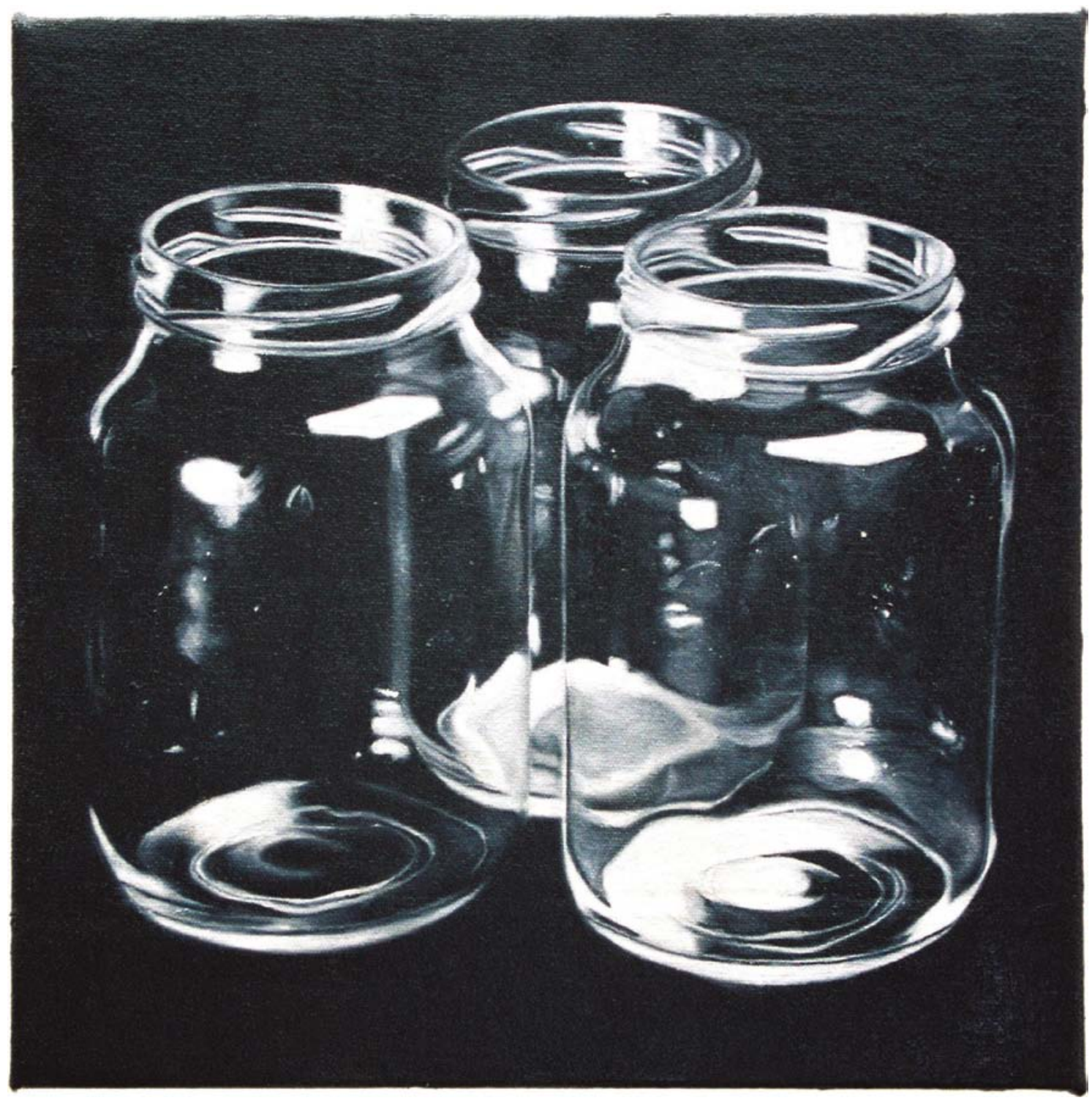




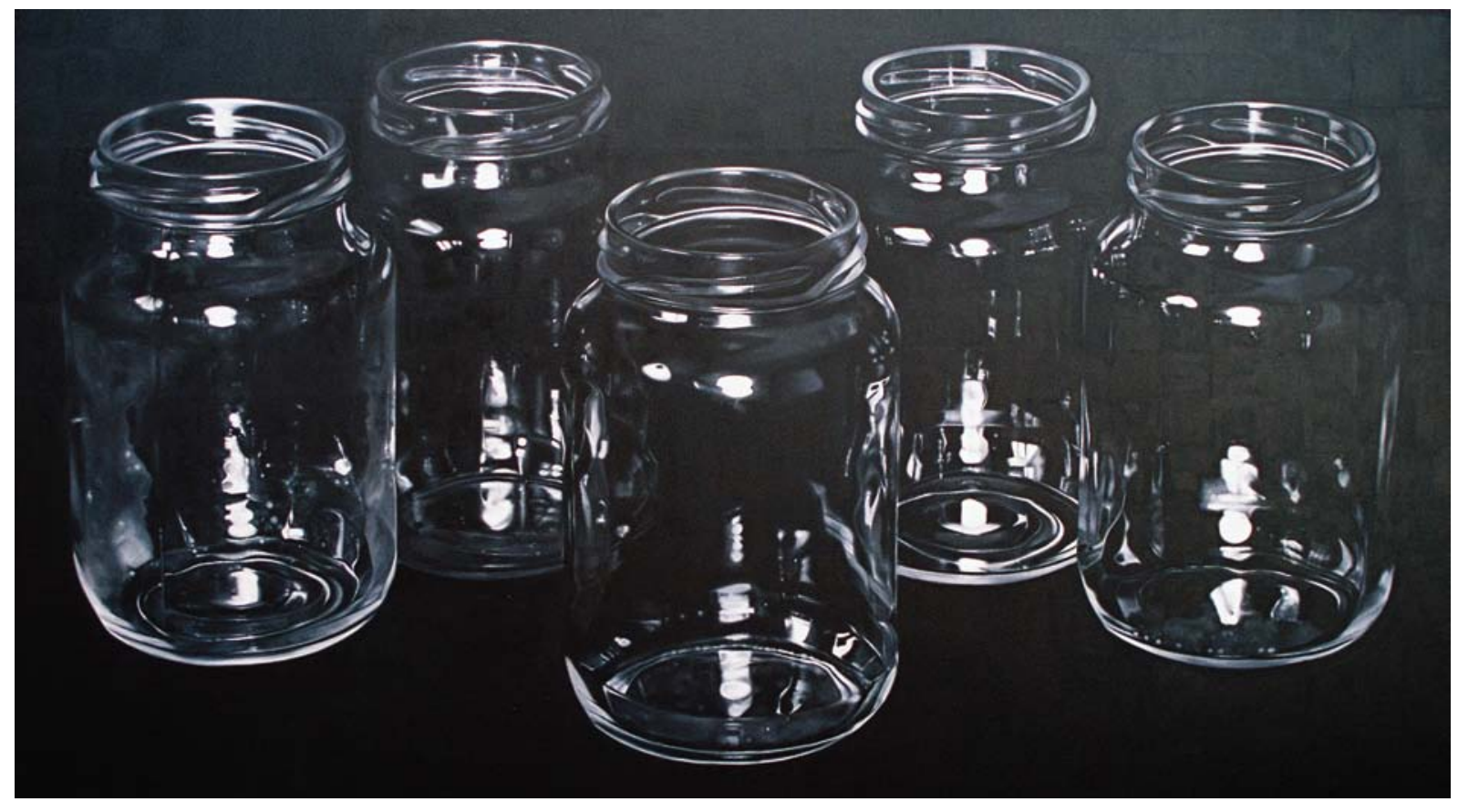

[5] 


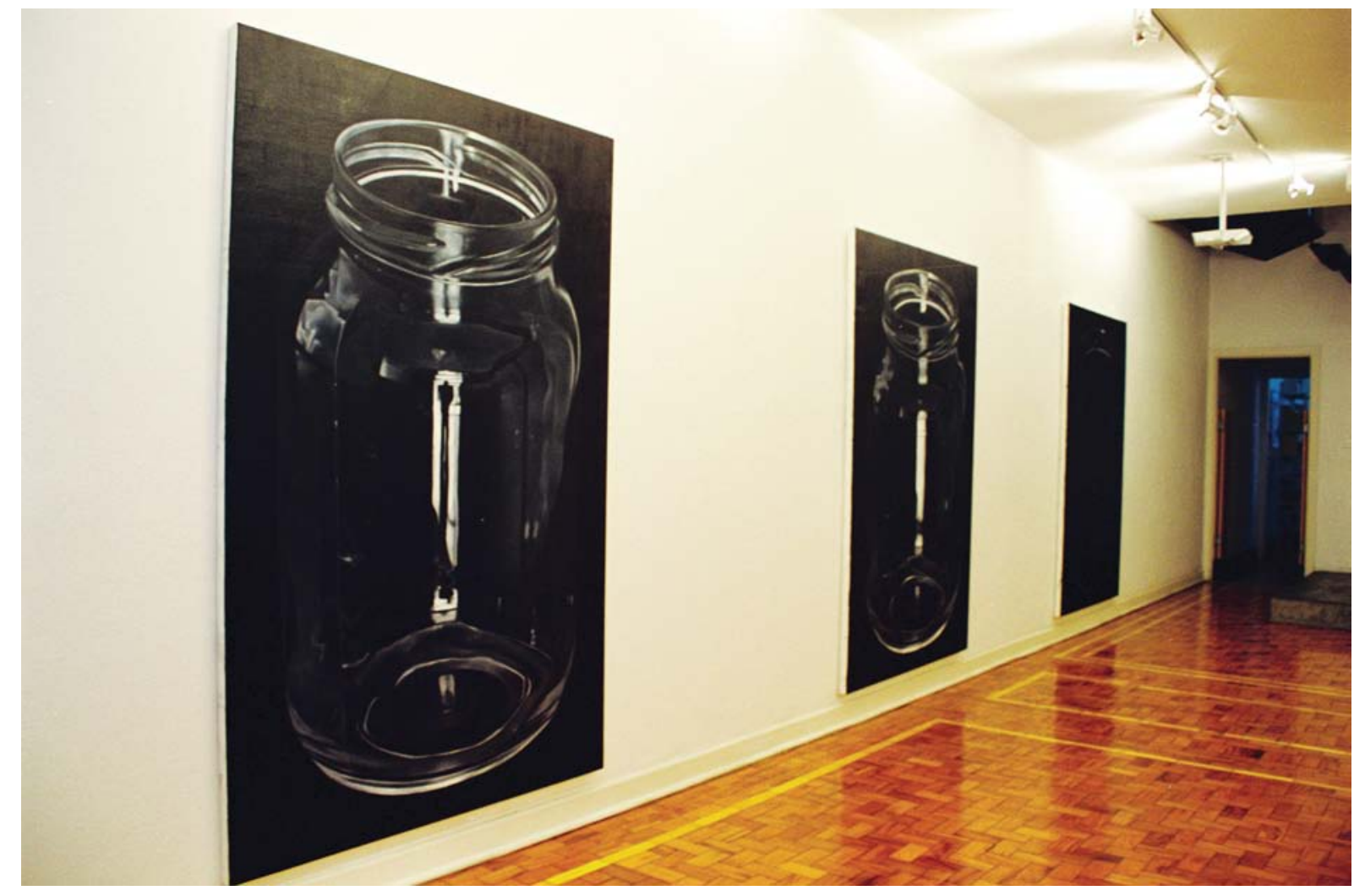




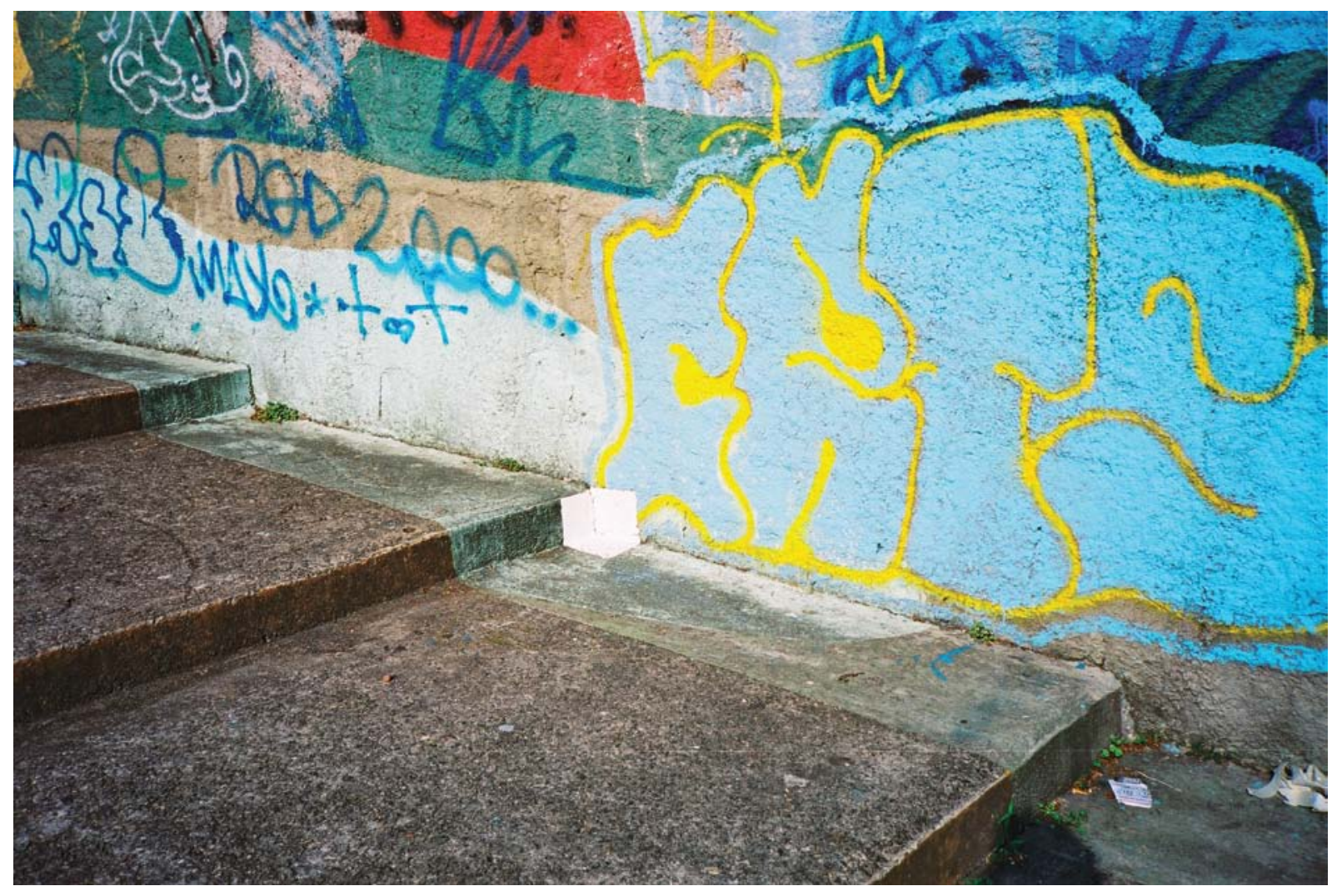

[7]

Cubo Branco, 2002

tinta acrílica, 14 x 14 x $14 \mathrm{~cm}$

47 


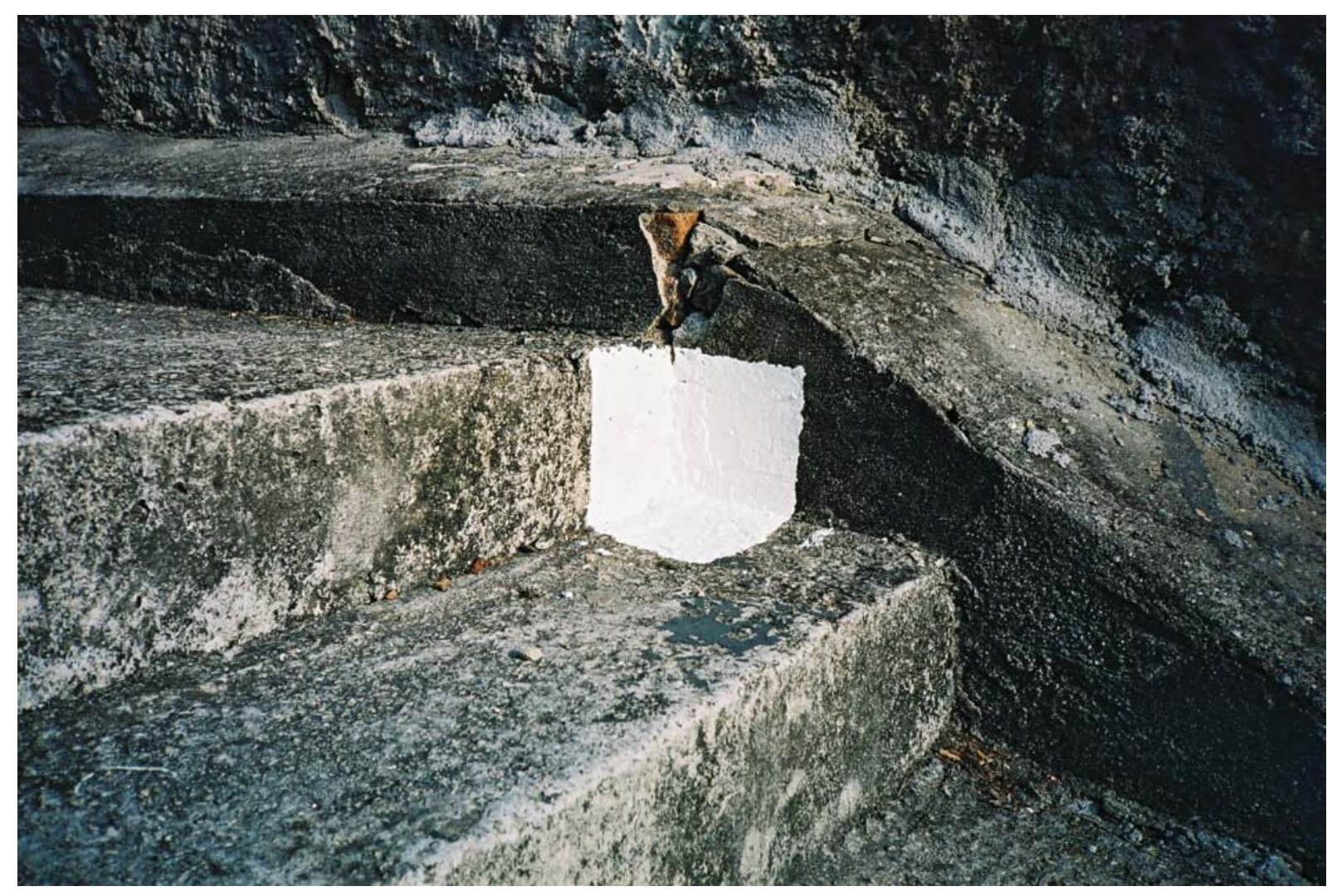




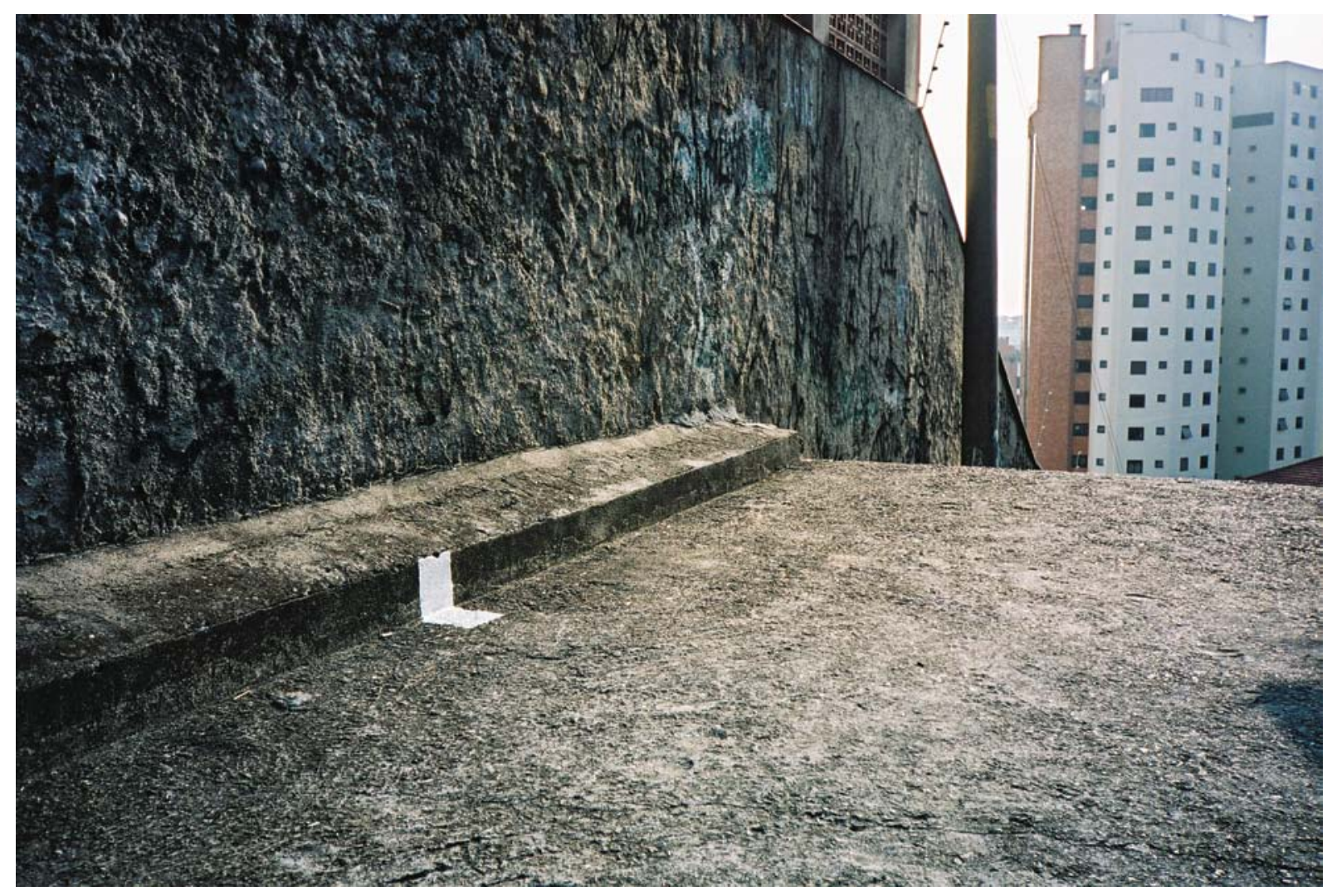

[9]

Cubo Branco, 2002

tinta acrílica, 12 × $12 \times 12 \mathrm{~cm}$ 


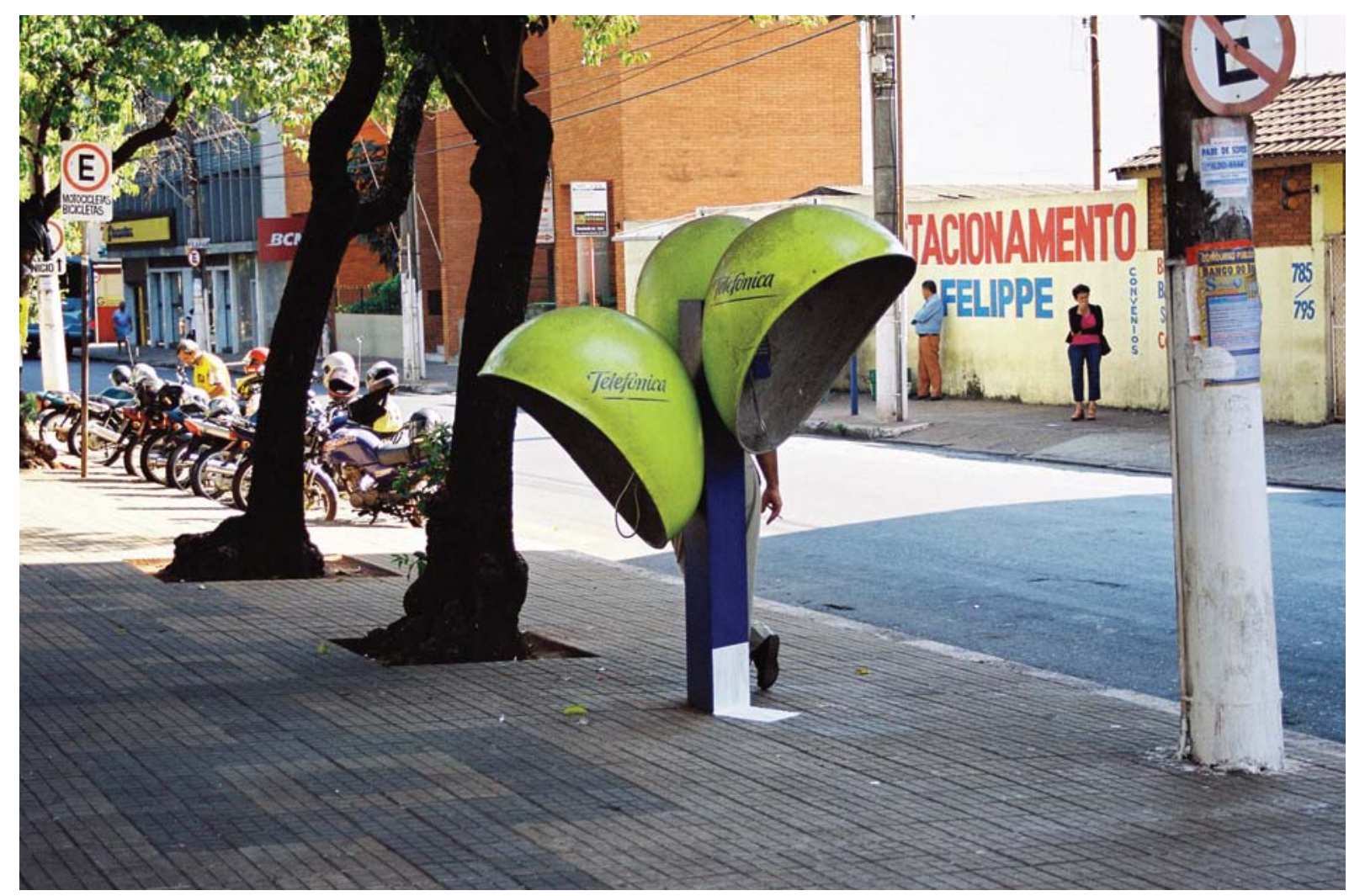




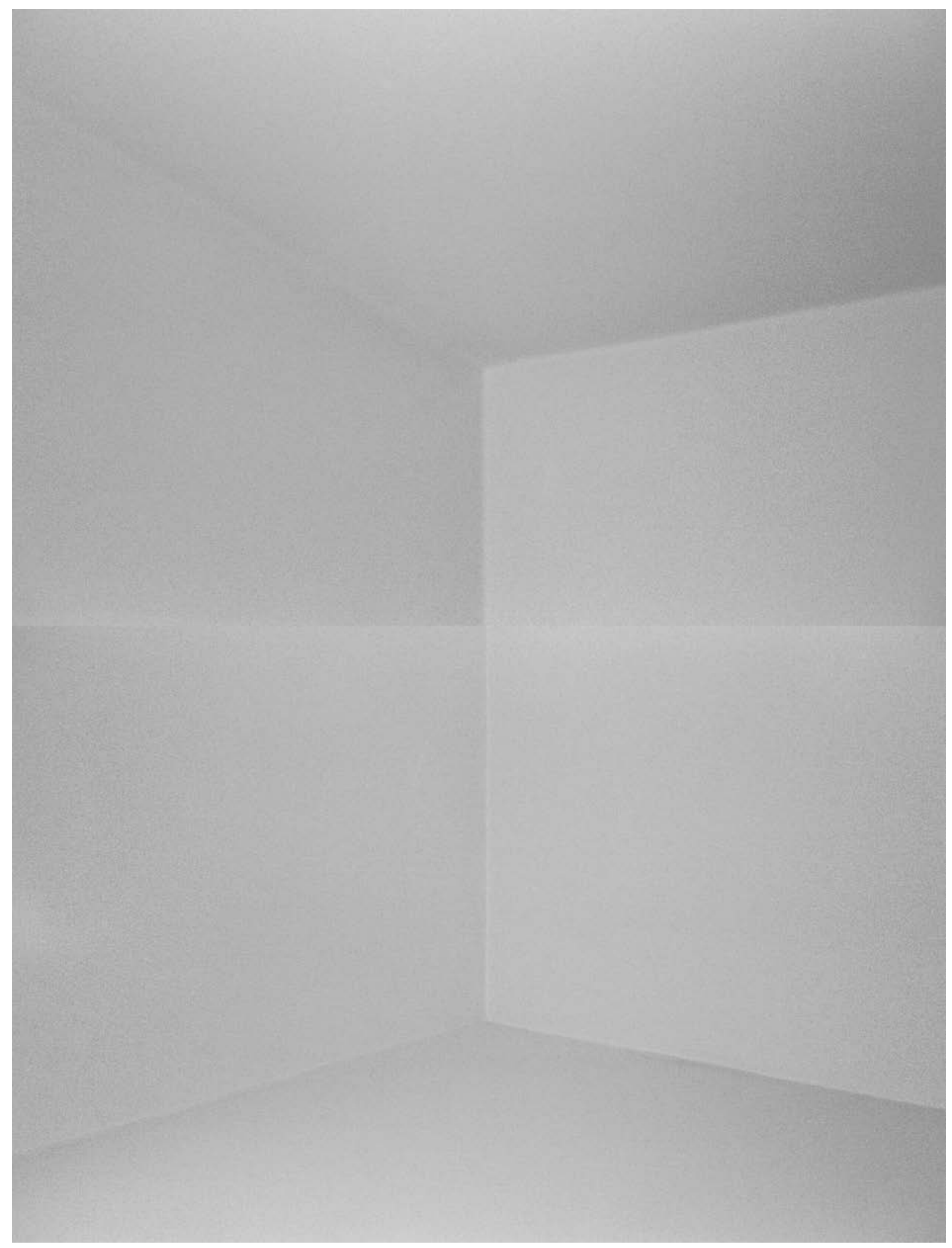

[11]

Canto, 2002

fotografia (díptico), $132 \times 100 \mathrm{~cm}$

51 


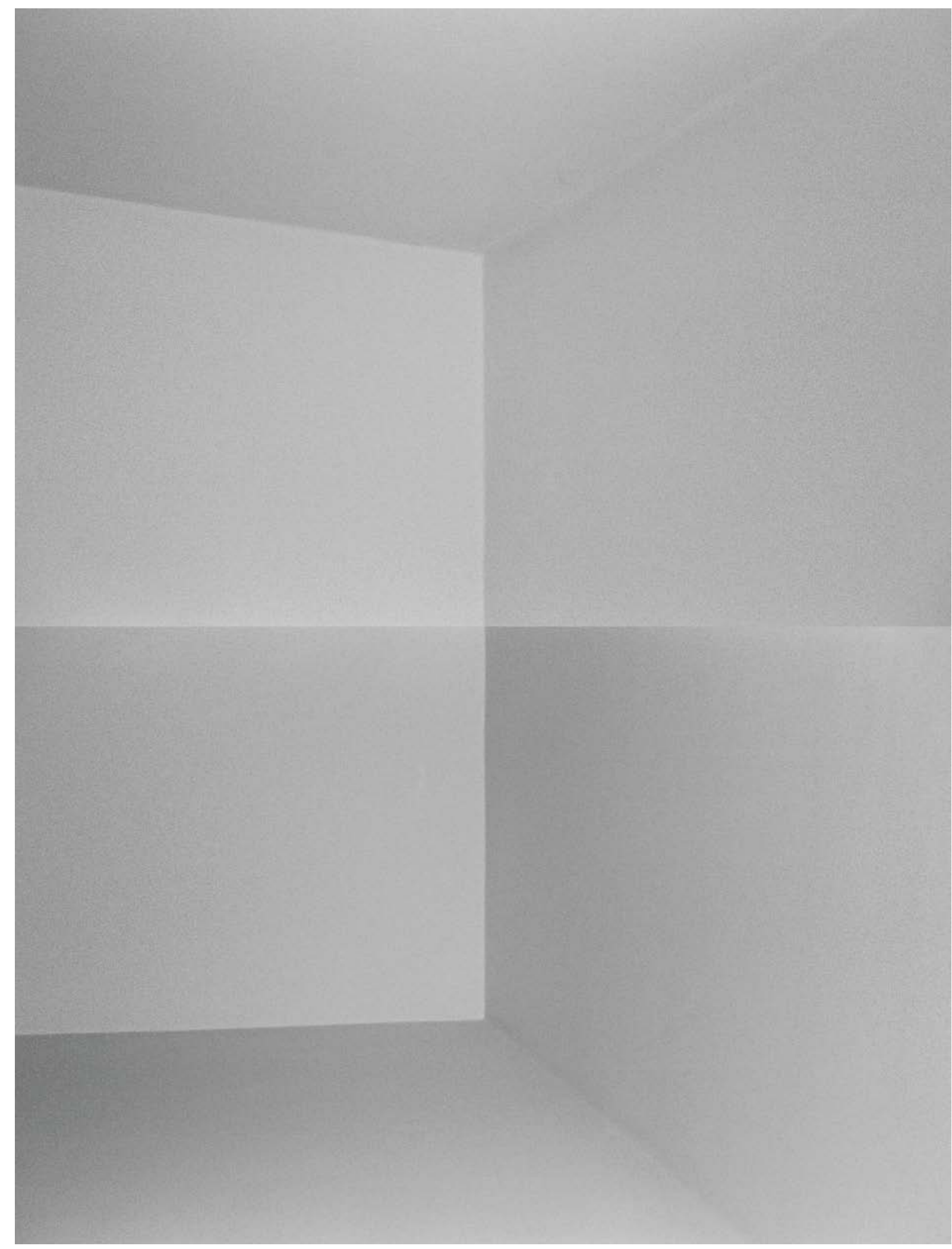

[12]

Canto, 2002 fotografia (díptico), 132 × $100 \mathrm{~cm}$ 


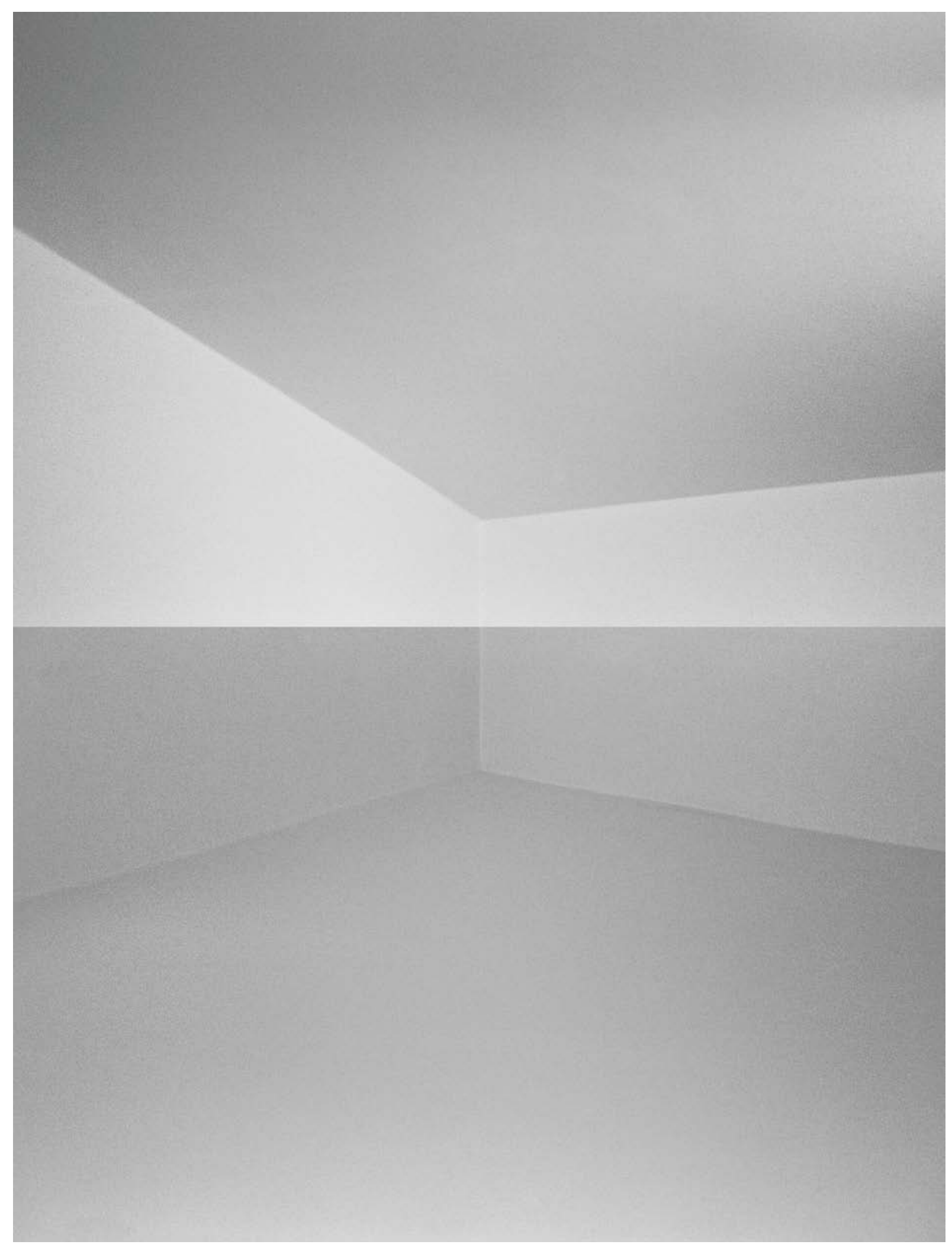

[13]

Canto, 2002

fotografia (díptico), $132 \times 100 \mathrm{~cm}$

53 


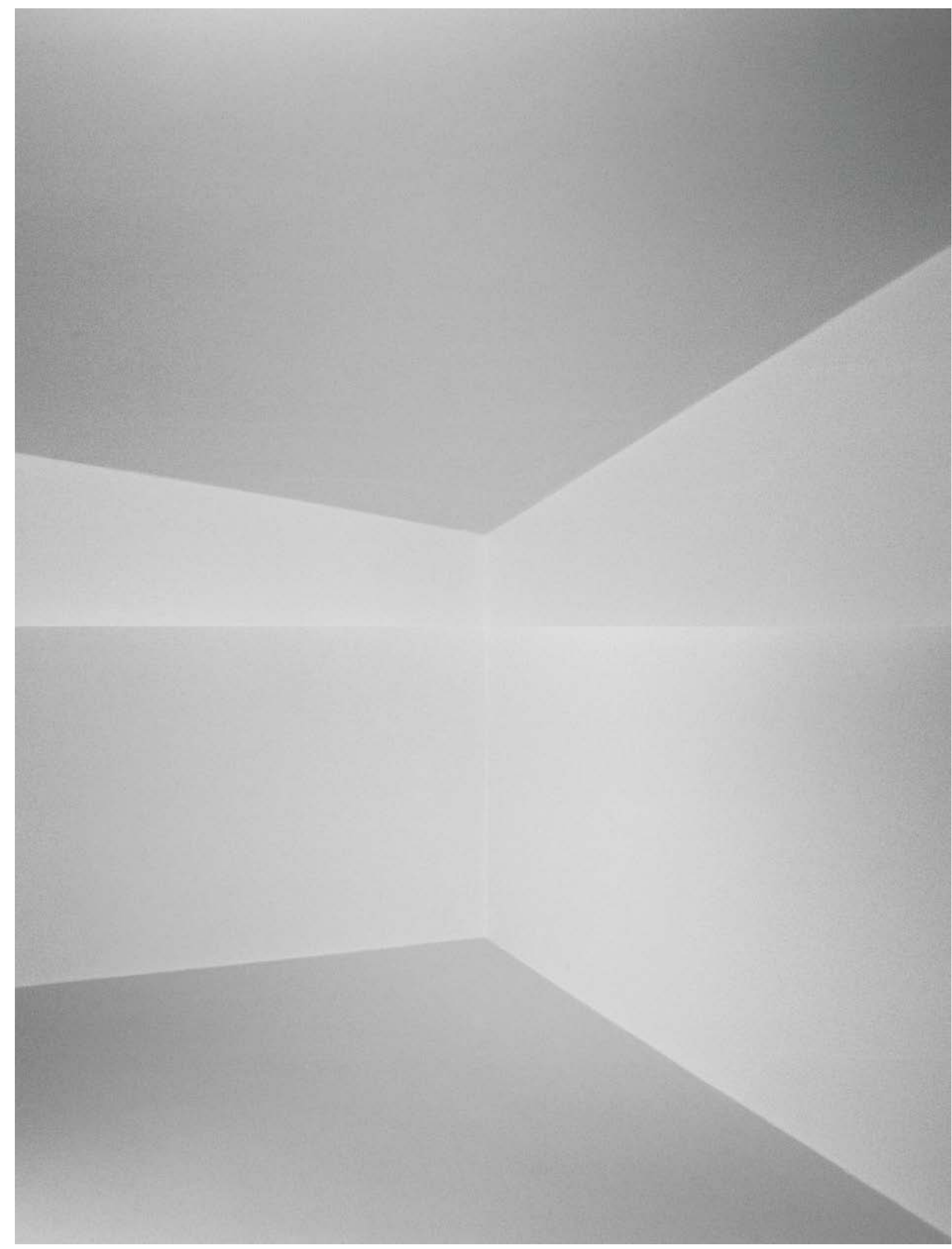

[14]

Canto, 2002 fotografia (díptico), 132 × $100 \mathrm{~cm}$ 


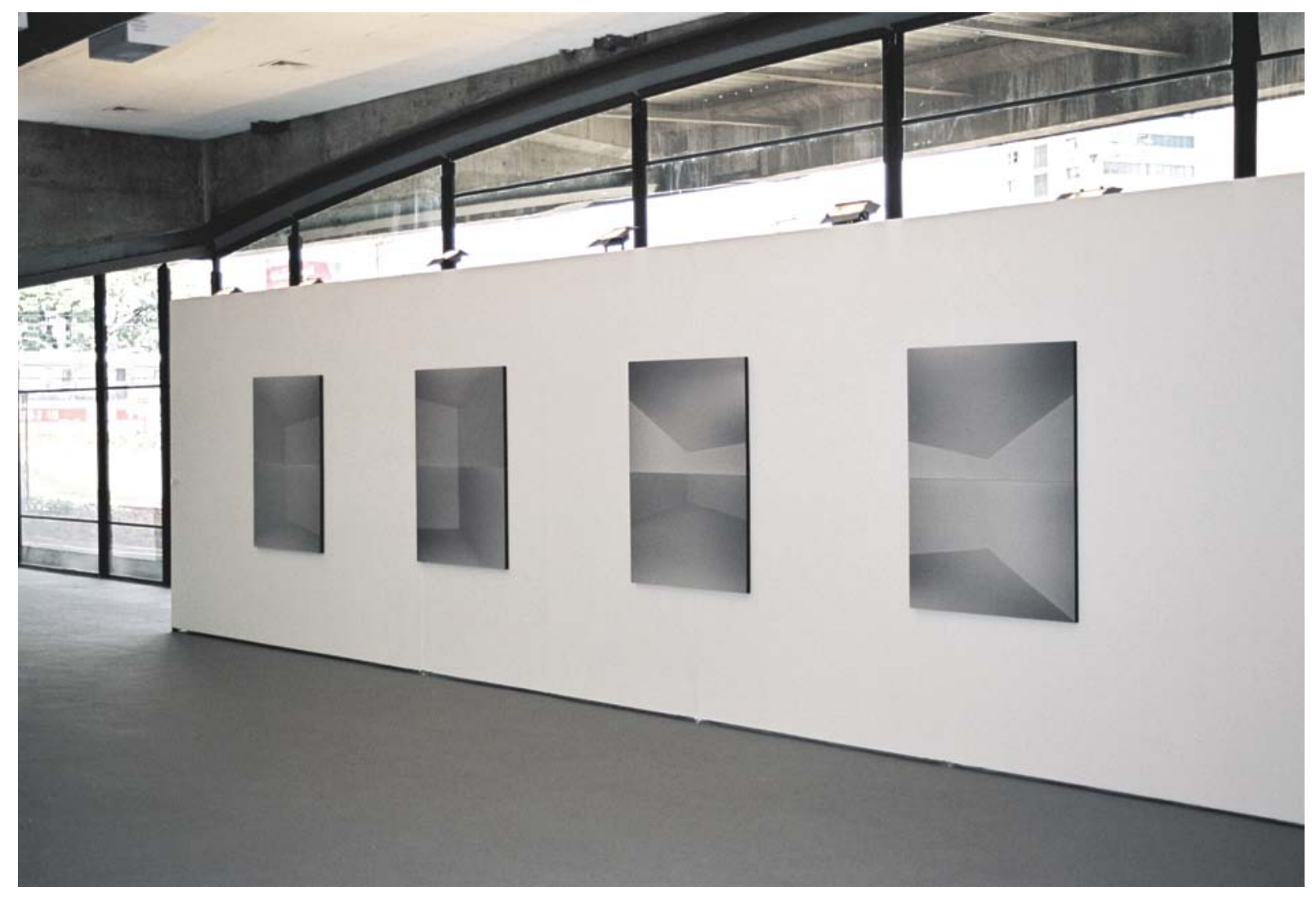

[15] 


$$
\square
$$




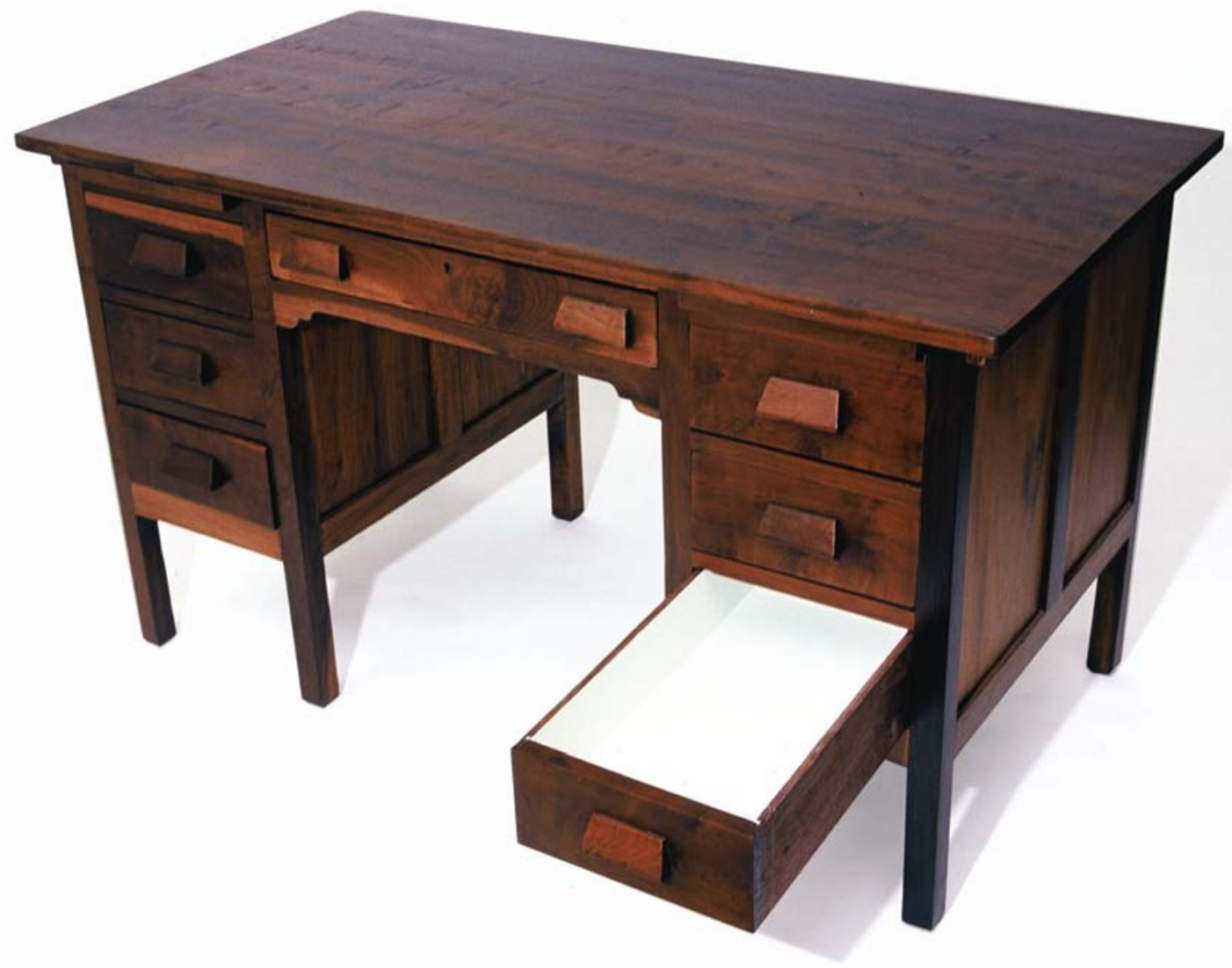

[17]

Cubo Branco, 2003

móvel de madeira, massa corrida e tinta acrílica. 81 × 139 × $108 \mathrm{~cm}$

57 


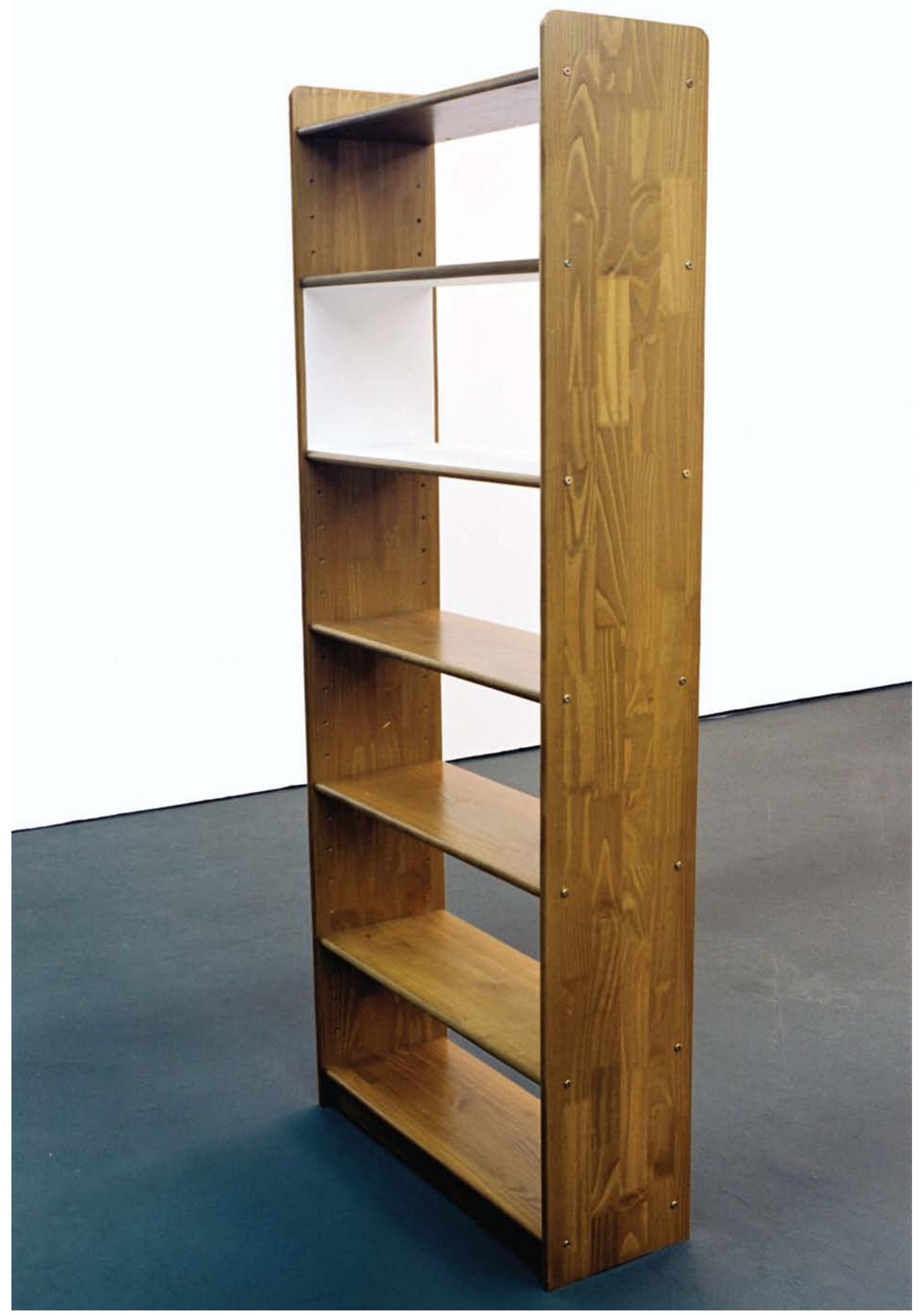

[18]

Cubo Branco, 2003 móvel de madeira, massa corrida e tinta acrílica. $200 \times 79 \times 30 \mathrm{~cm}$ 


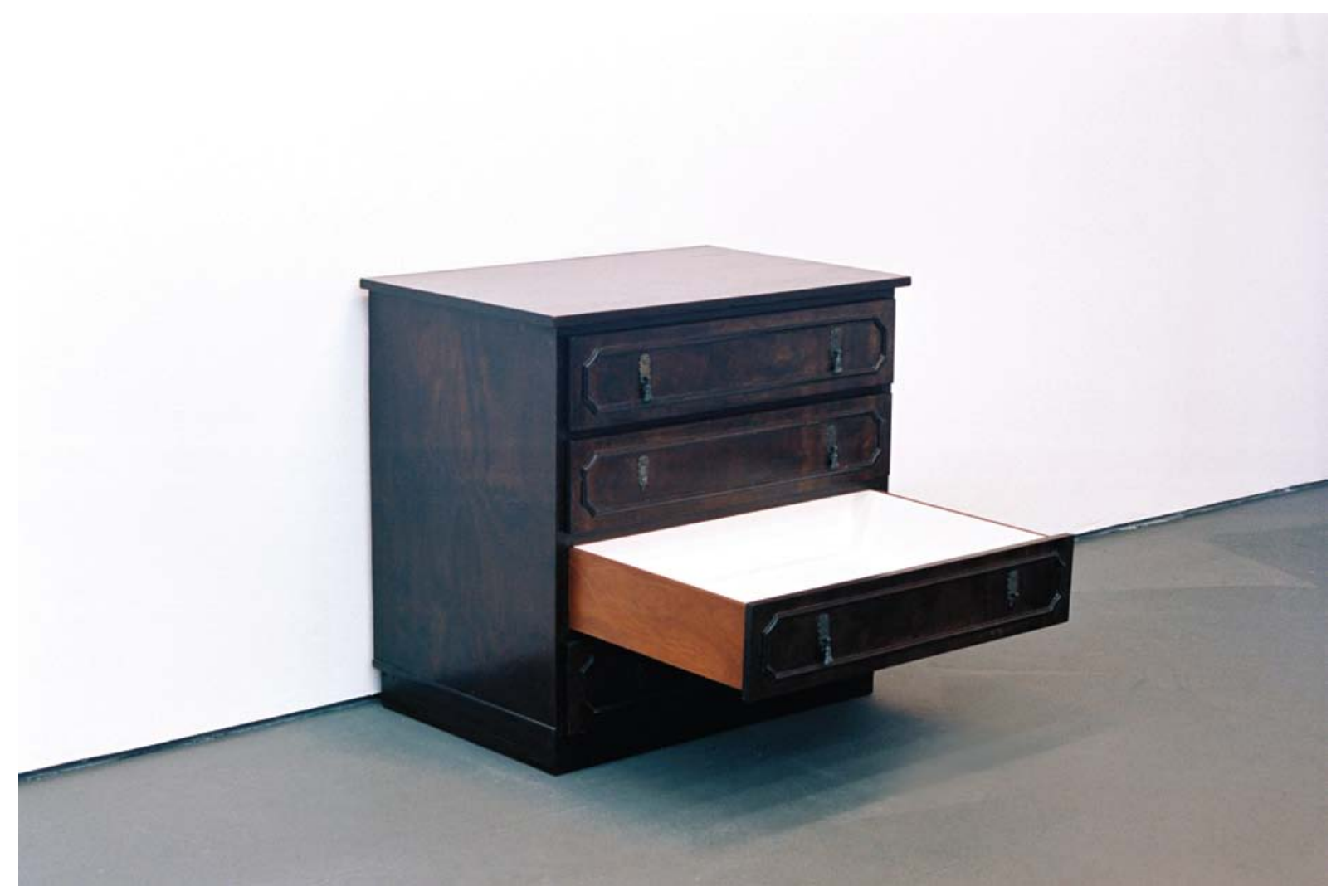

[19]

Cubo Branco, 2003

móvel de madeira, massa corrida e tinta acrílica. 85 × 90 × $105 \mathrm{~cm}$ 


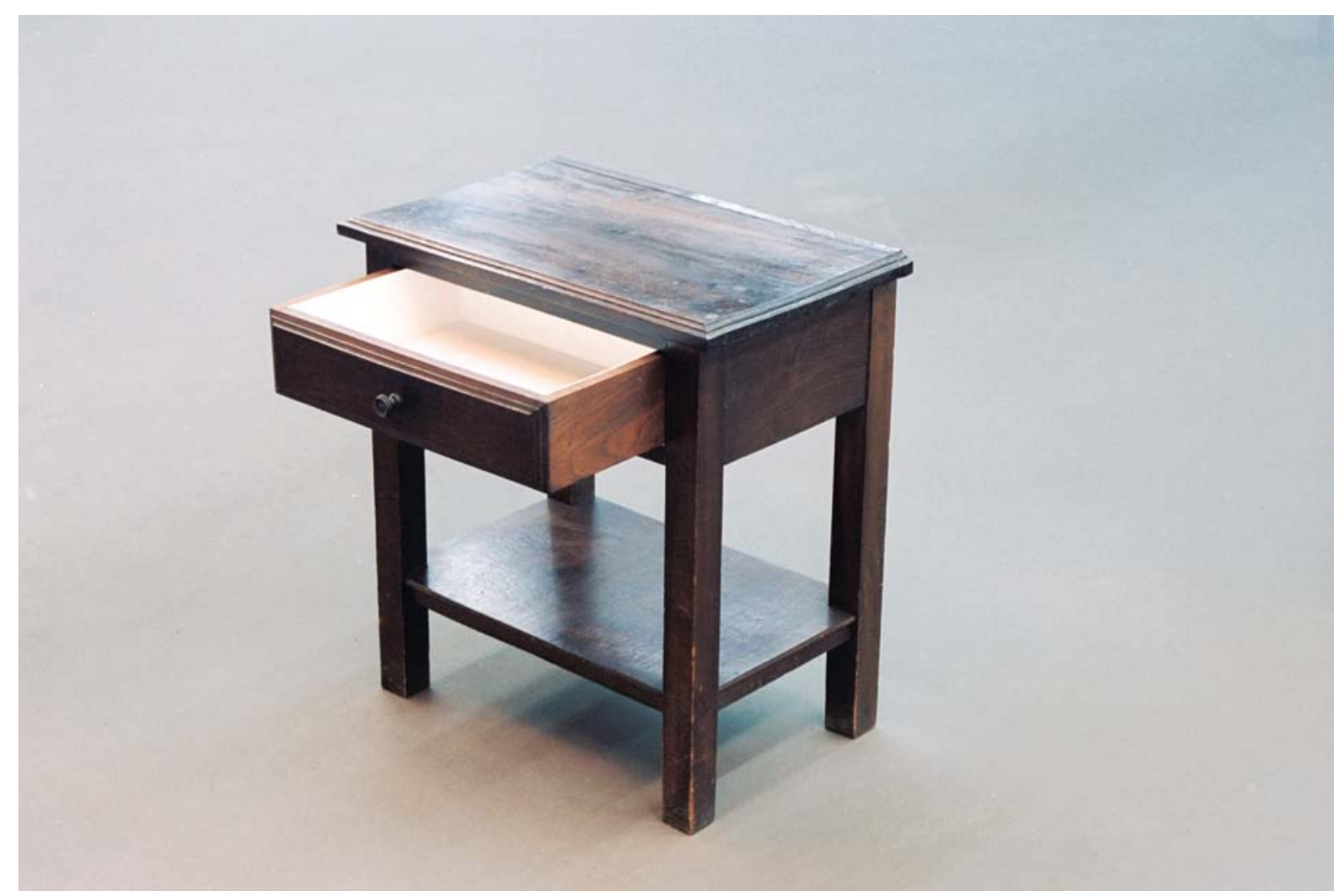




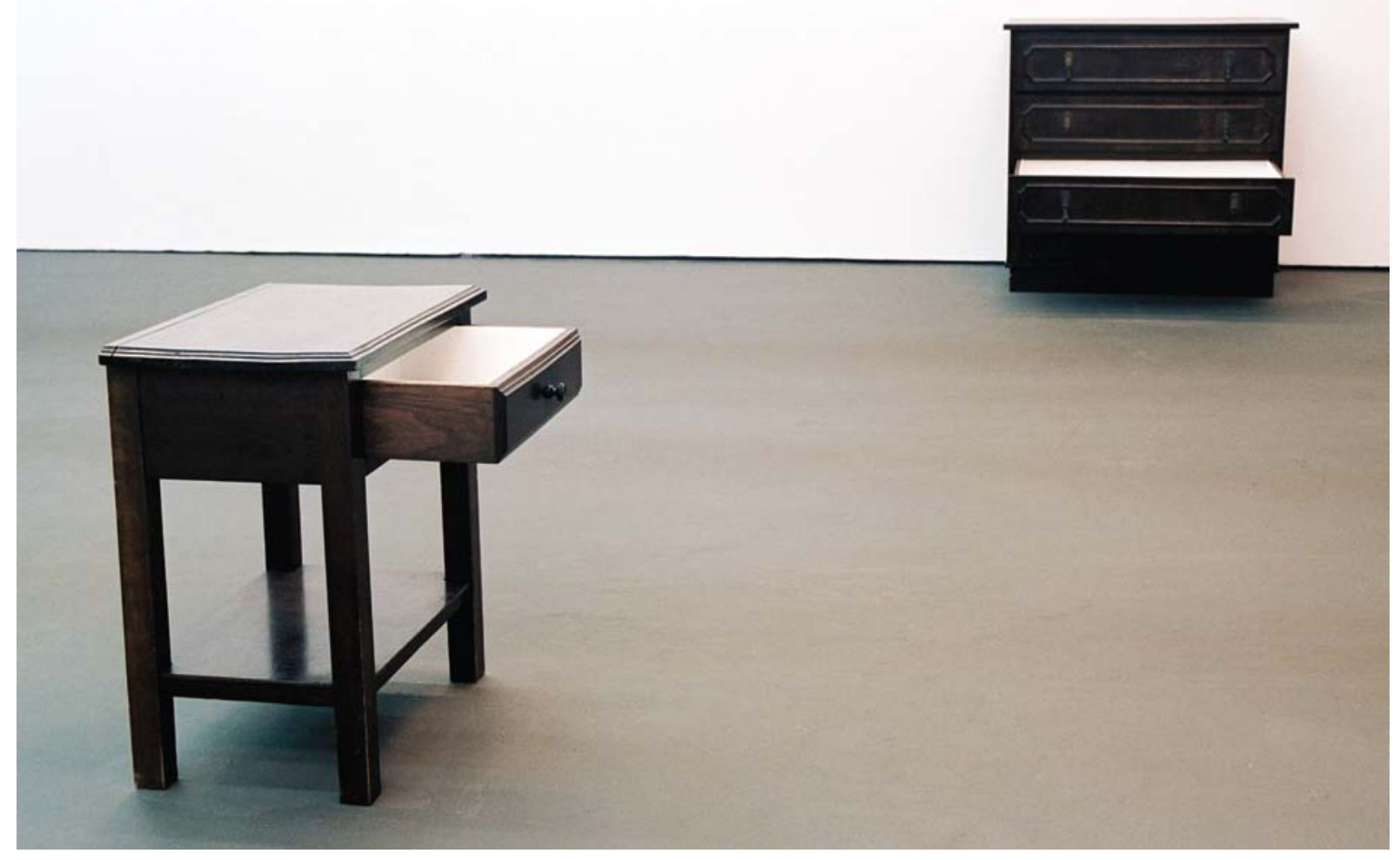

[21]

Centro Cultural São Paulo, 2003

61 


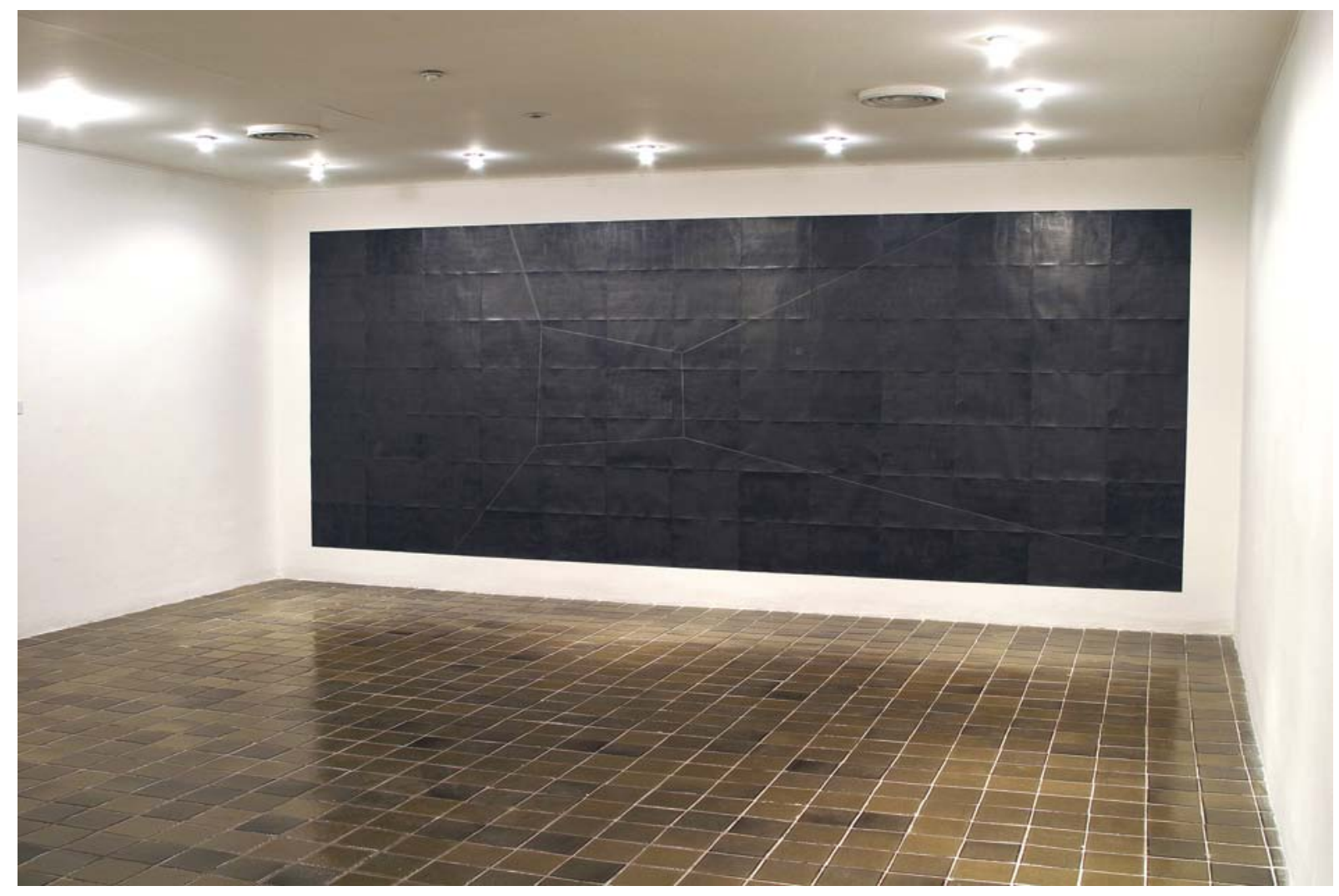

[22]

Espaço, 2004

grafite sobre papel. $208 \times 588 \mathrm{~cm}$ 


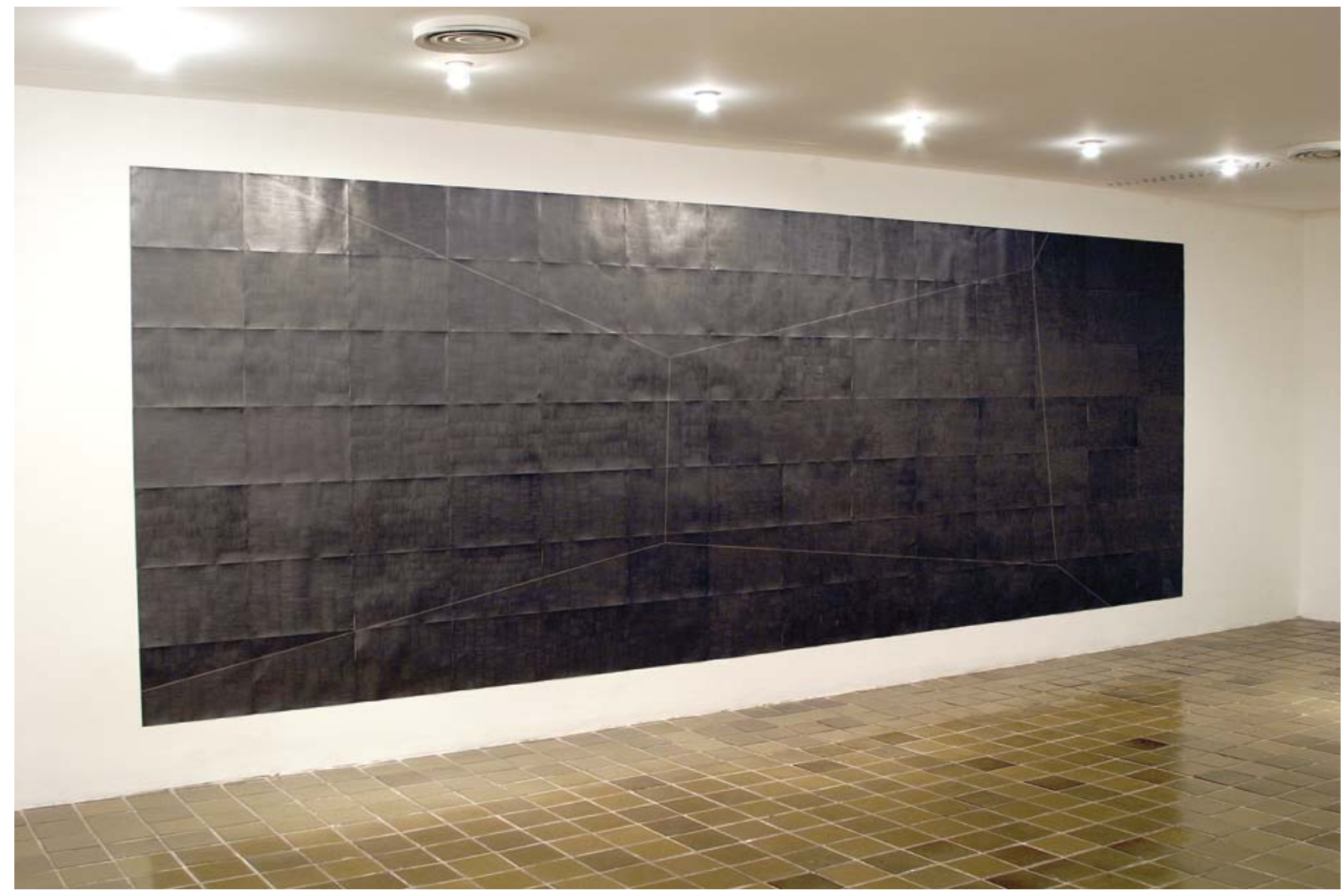

[23]

Espaço, 2004

grafite sobre papel. $208 \times 588 \mathrm{~cm}$ 


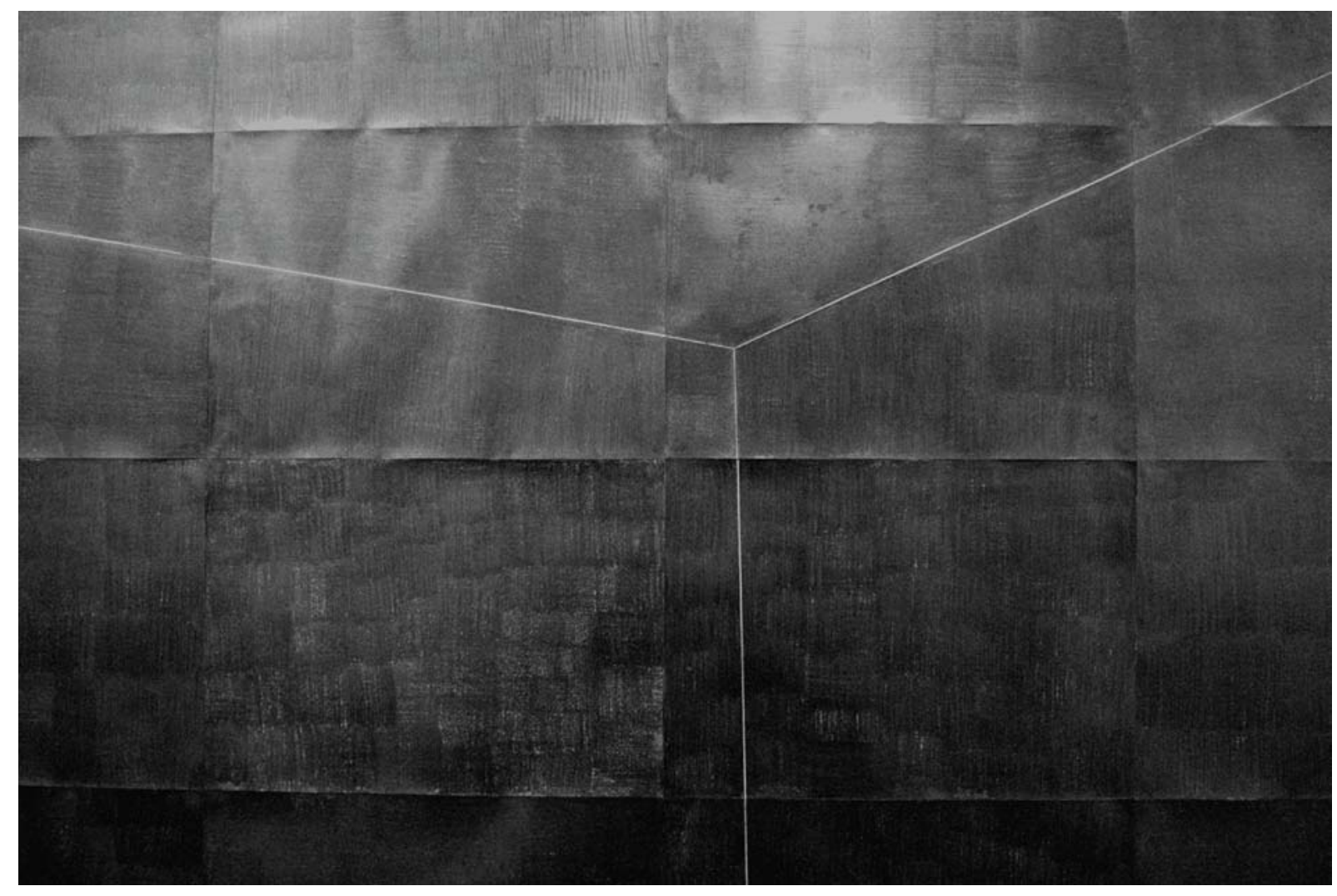

[24]

Espaço (detalhe), 2004 grafite sobre papel. $208 \times 588 \mathrm{~cm}$ 


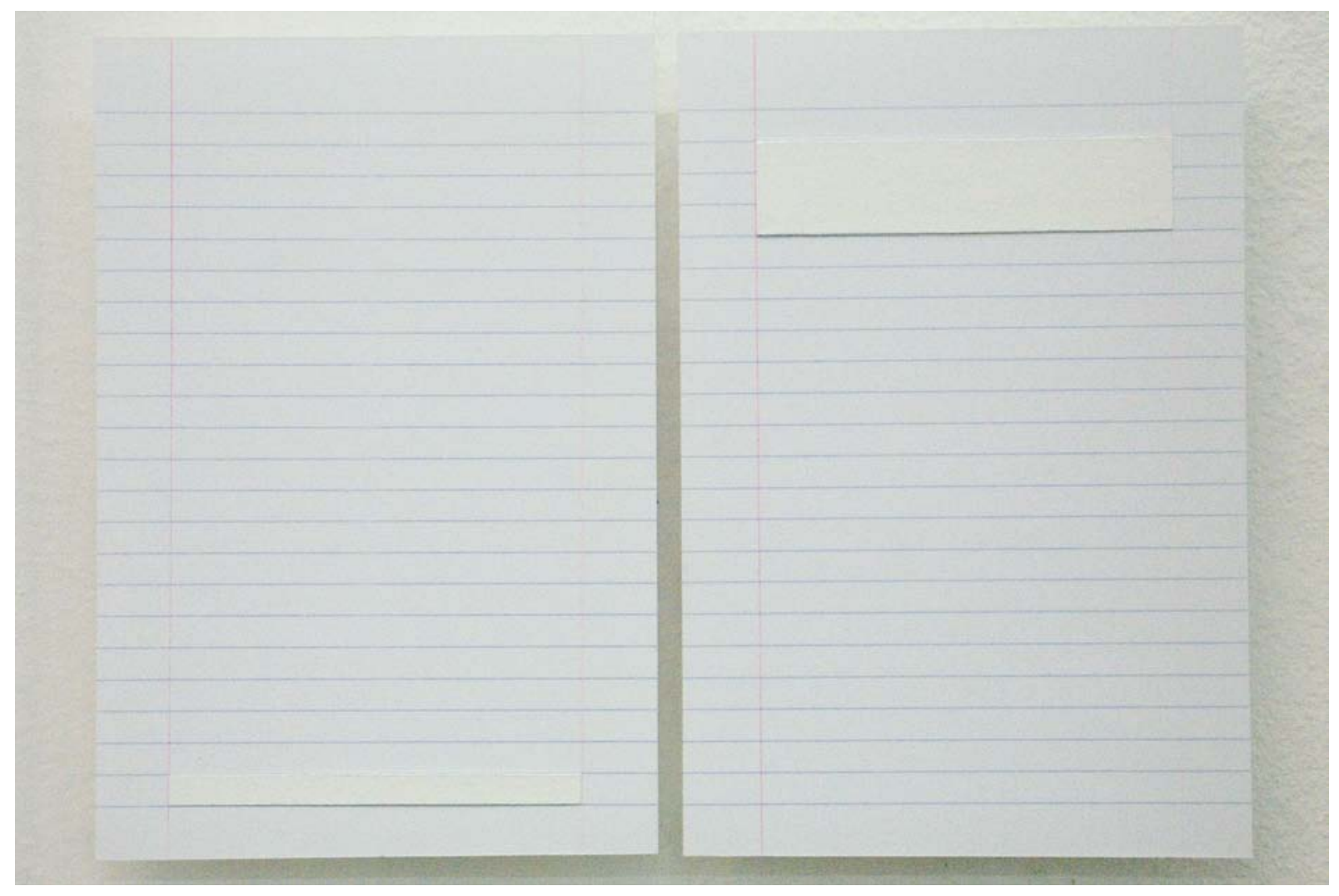

[25]

Preciso lavar carro farmácia pintar quadro, 2005

massa corrida e tinta acrílica sobre folha de caderno. 21,00 x 31,00 cm

65 


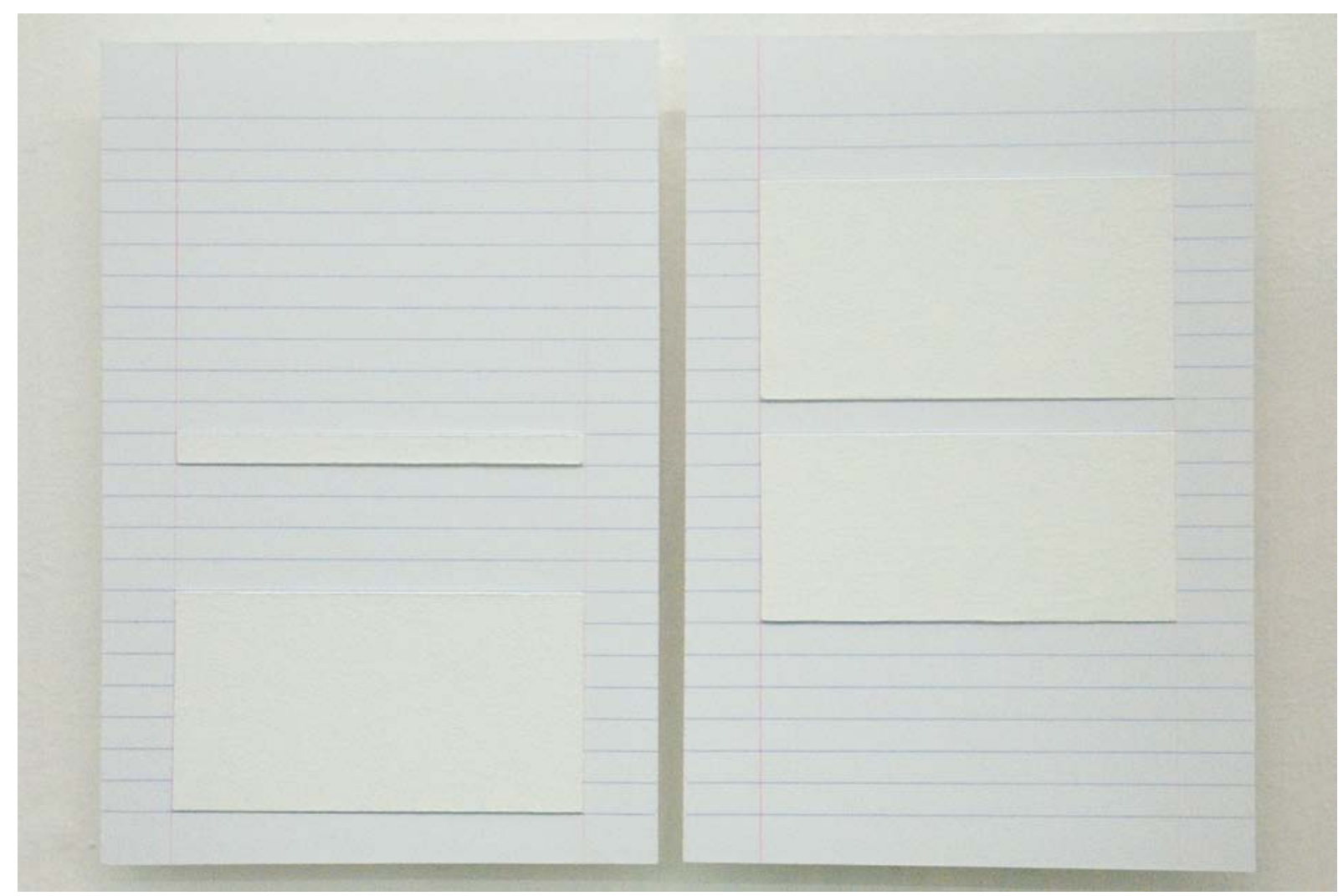
massa corrida e tinta acrílica sobre folha de caderno. $21,00 \times 31,00 \mathrm{~cm}$ 


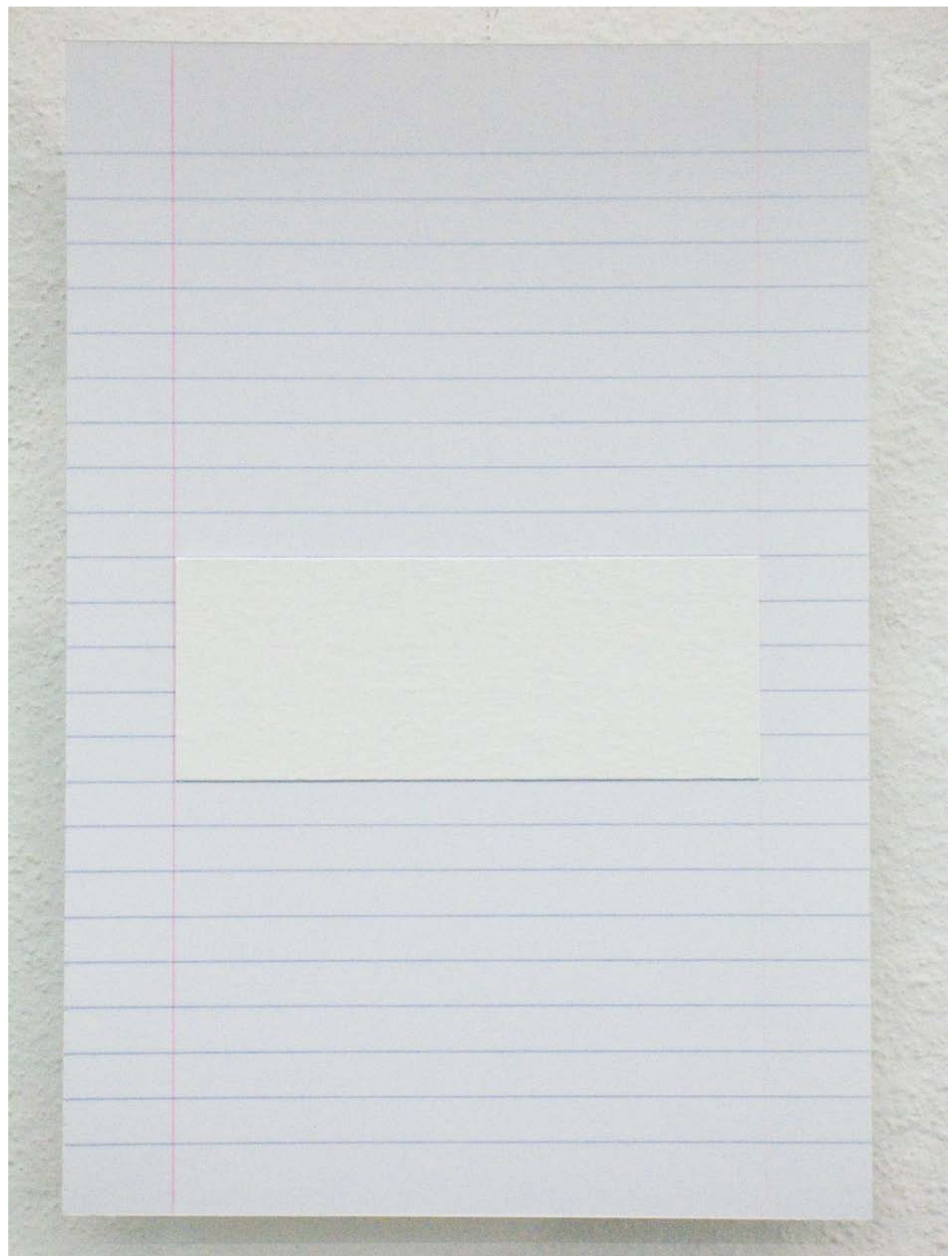

[27]

Quarta 11:00 5० andar tentar alternativa, 2005 massa corrida e tinta acrílica sobre folha de caderno. 21,00 x 14,80 cm 


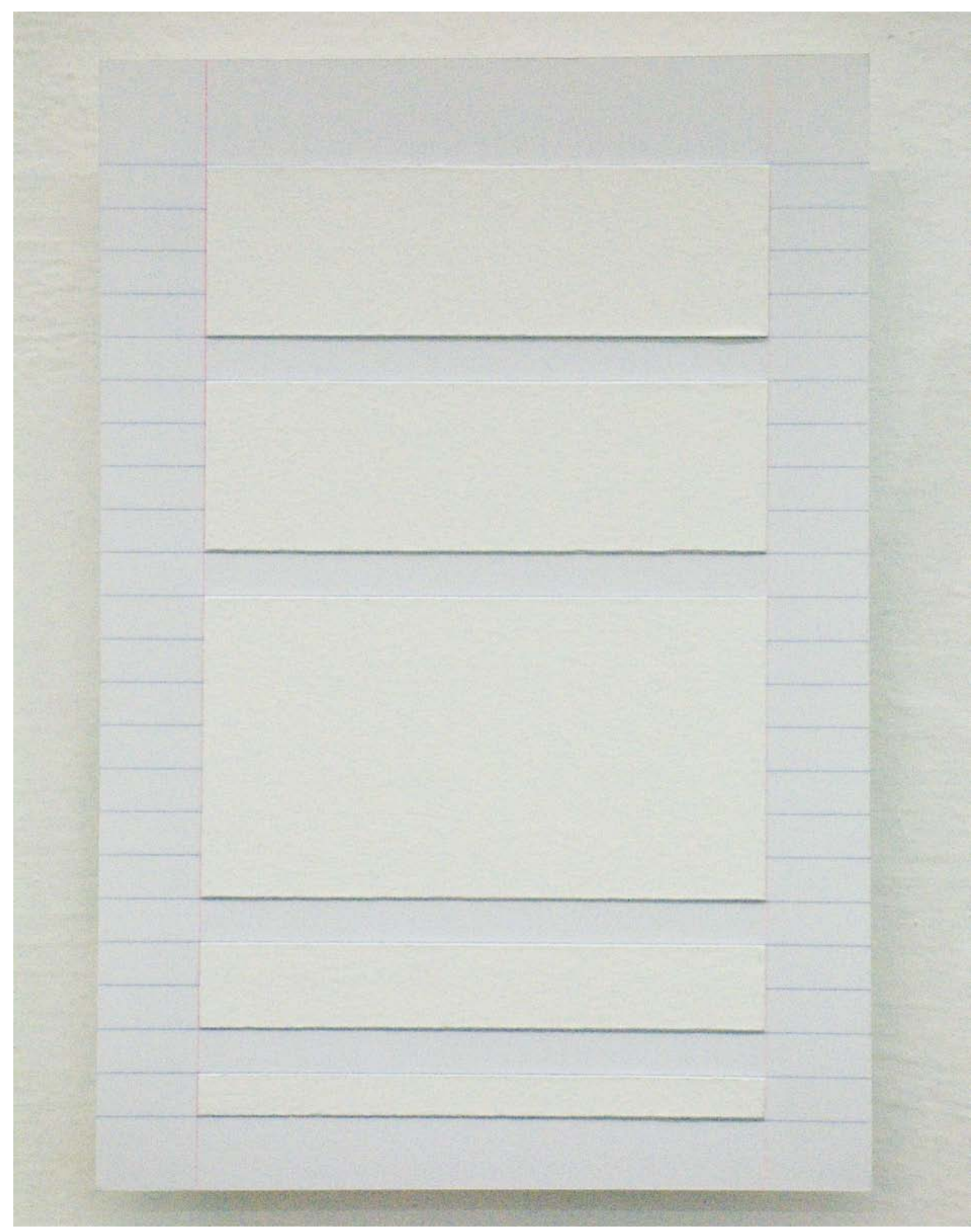
massa corrida e tinta acrílica sobre folha de caderno. 21,00 x 14,80 cm 


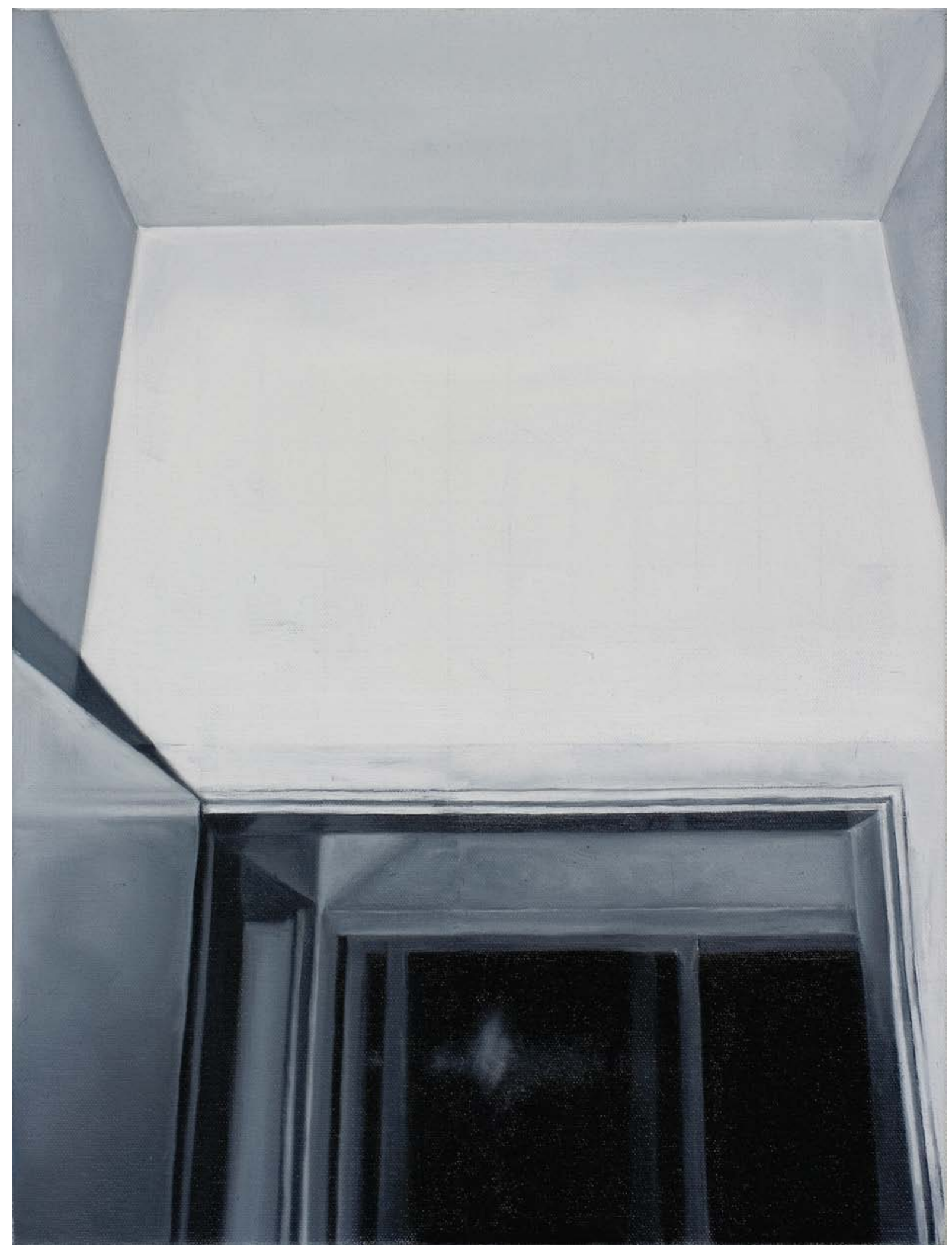

[29]

Vago, 2005

óleo sobre tela. $40 \times 30 \mathrm{~cm}$ 


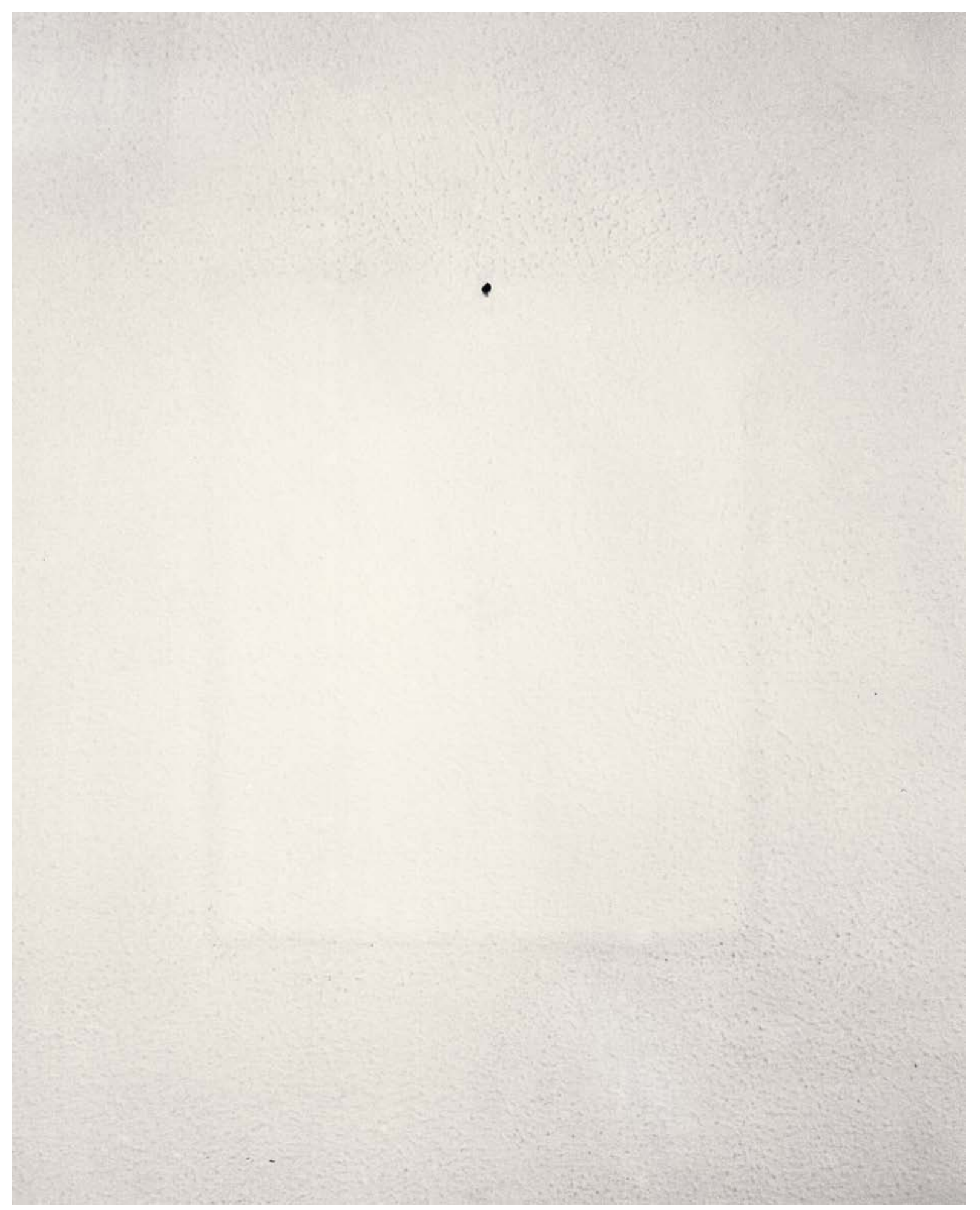

[30]

Pintura, 2006

fotografia, $100 \times 80 \mathrm{~cm}$ 


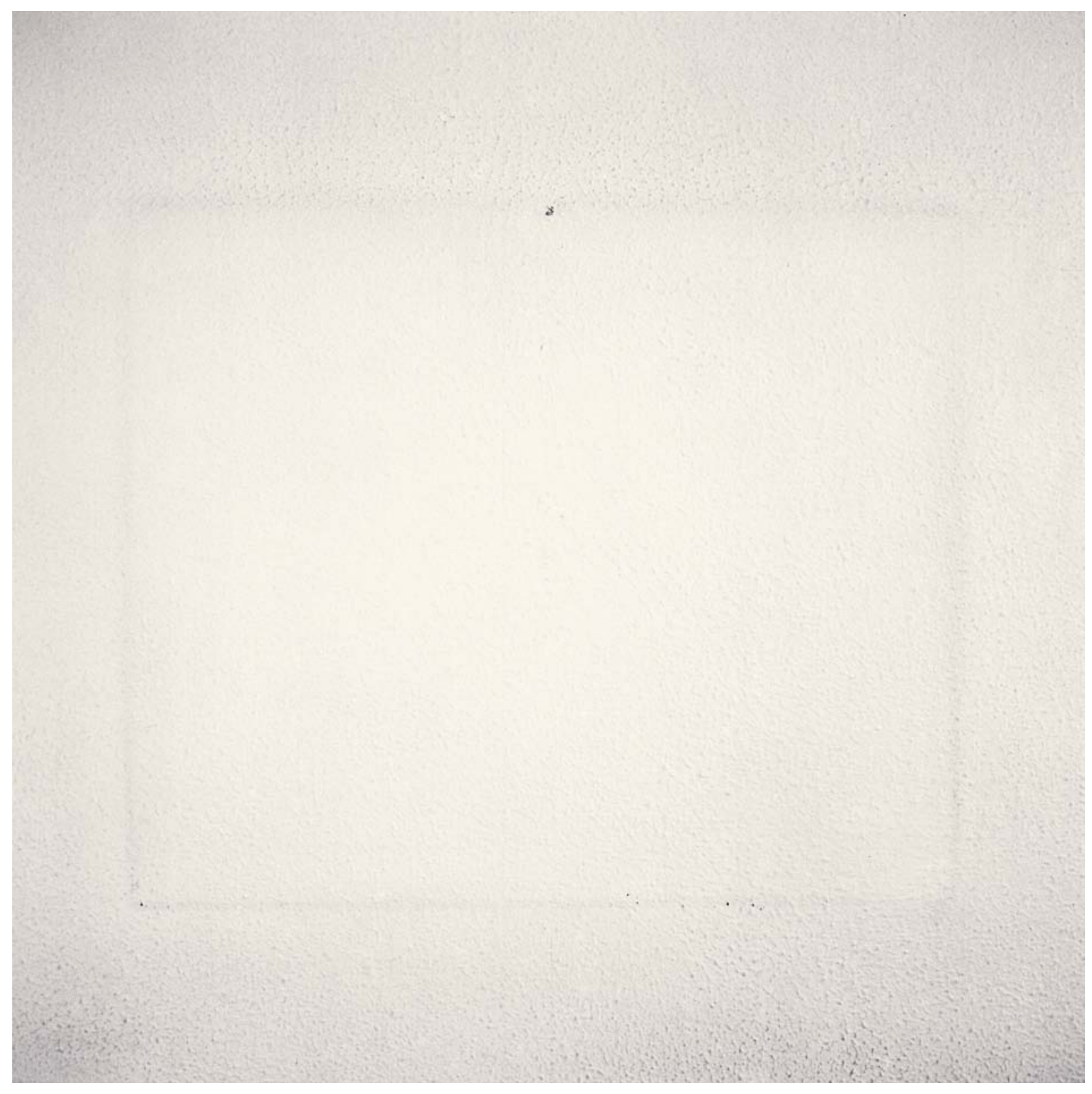

[31]

Pintura, 2006

fotografia. $100 \times 100 \mathrm{~cm}$

71 


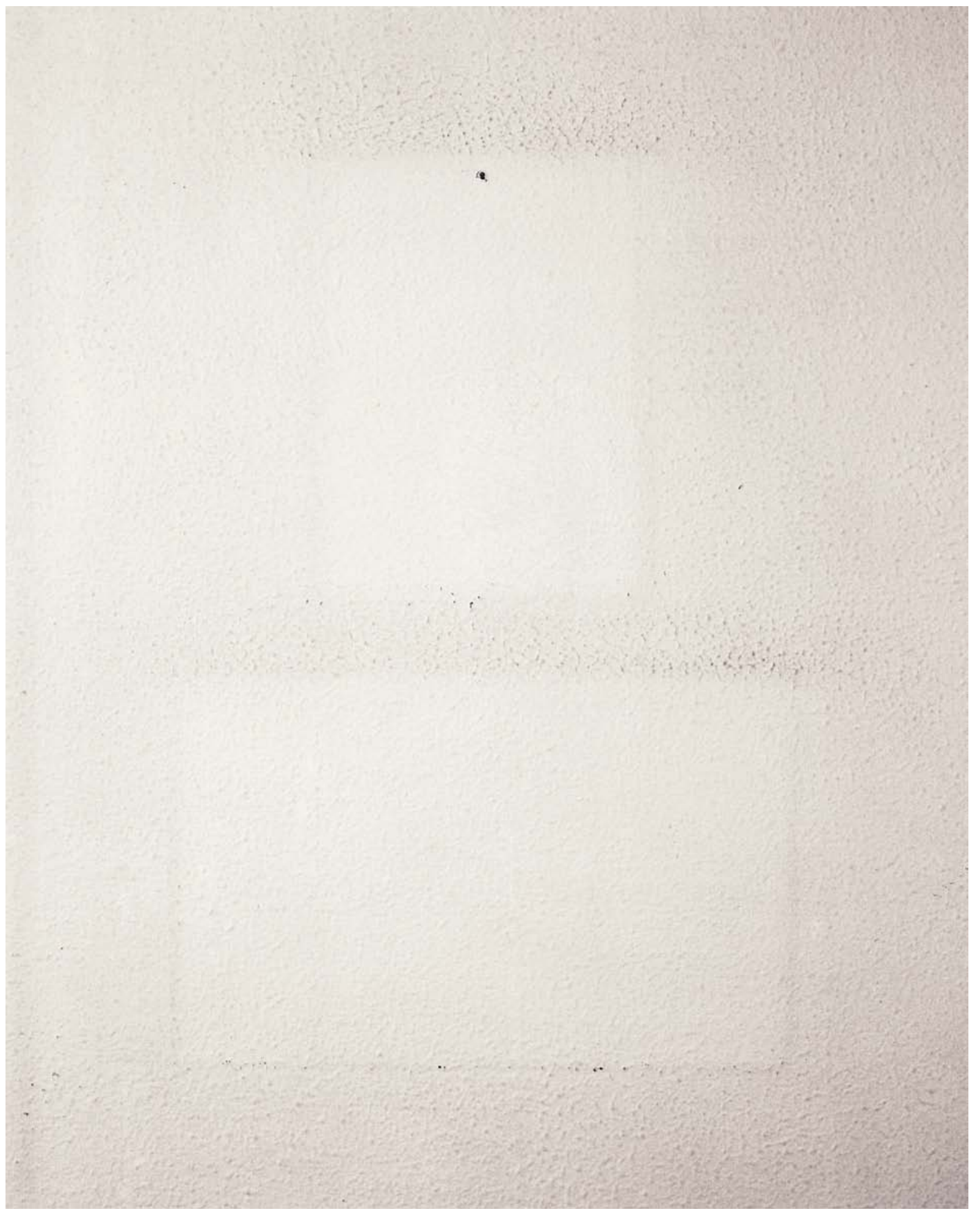

[32]

Pinturas, 2006

fotografia. $100 \times 80 \mathrm{~cm}$ 


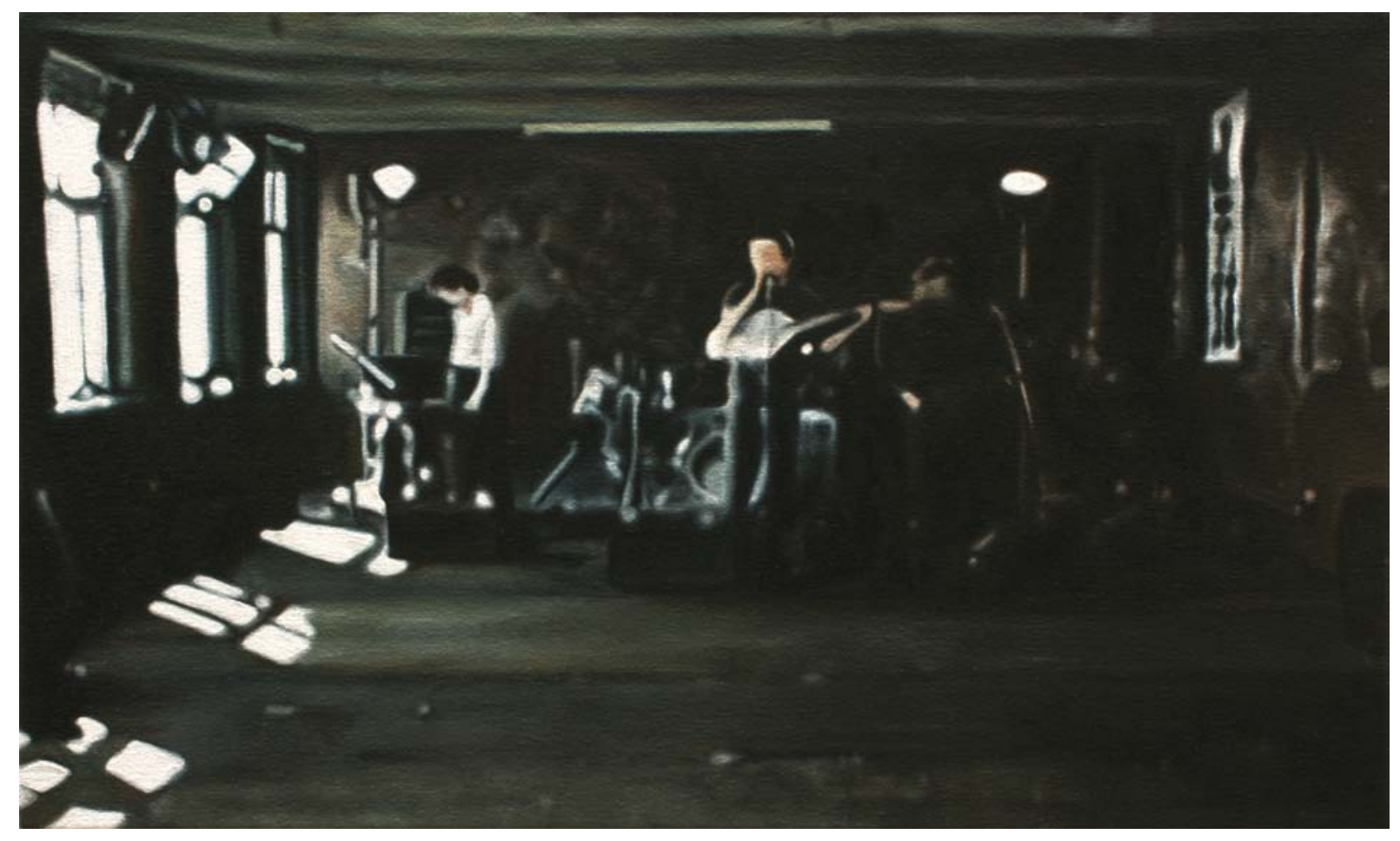

[33]

When routine bites hard, 2006

óleo sobre tela. $30 \times 50 \mathrm{~cm}$ 


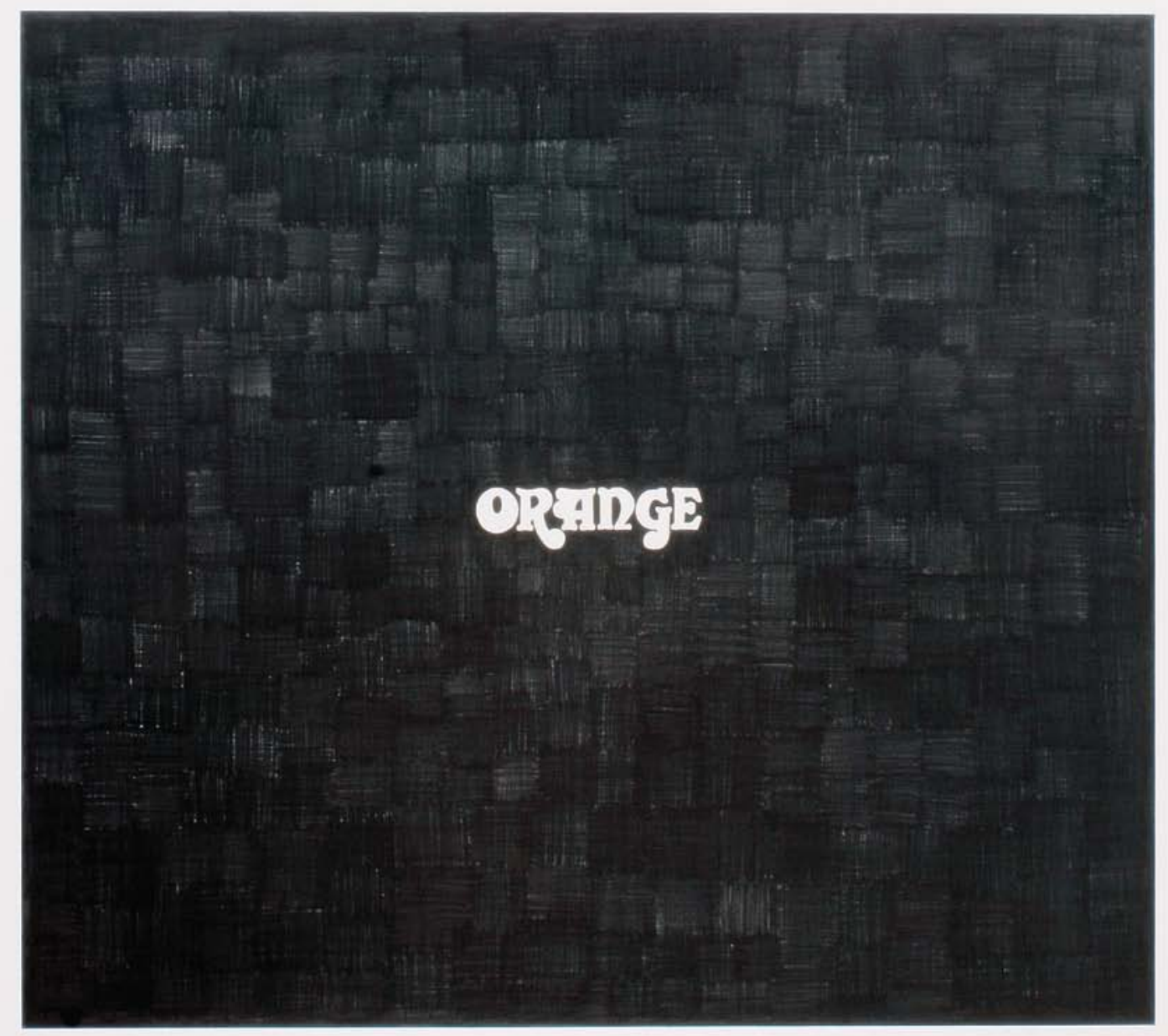

[34]

Amplificador, 2008

grafite sobre papel. $100 \times 70 \mathrm{~cm}$ 


\section{Marshall}

[35]

Amplificador, 2008

grafite sobre papel. $100 \times 70 \mathrm{~cm}$ 


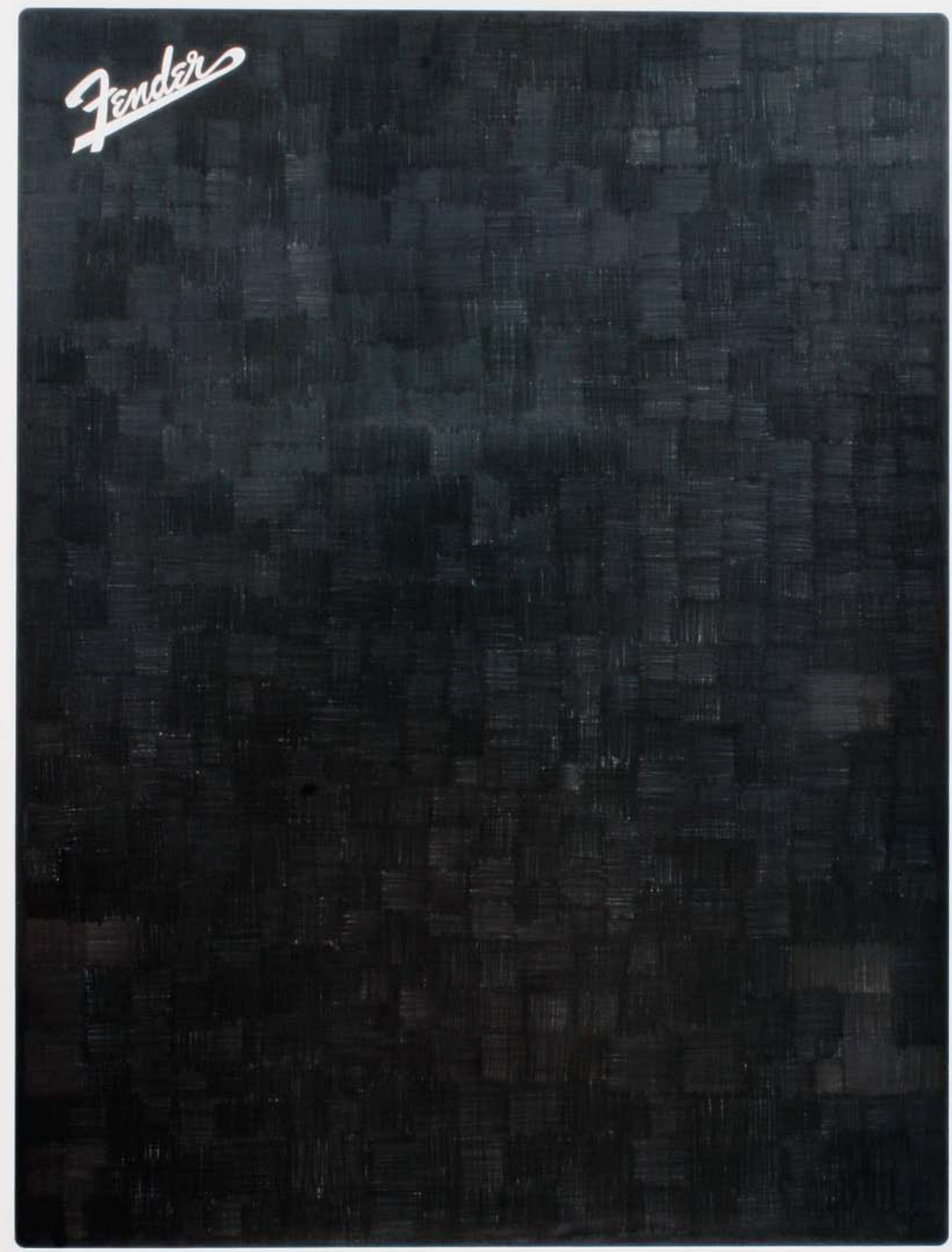

[36]

Amplificador, 2008

grafite sobre papel. $100 \times 70 \mathrm{~cm}$ 


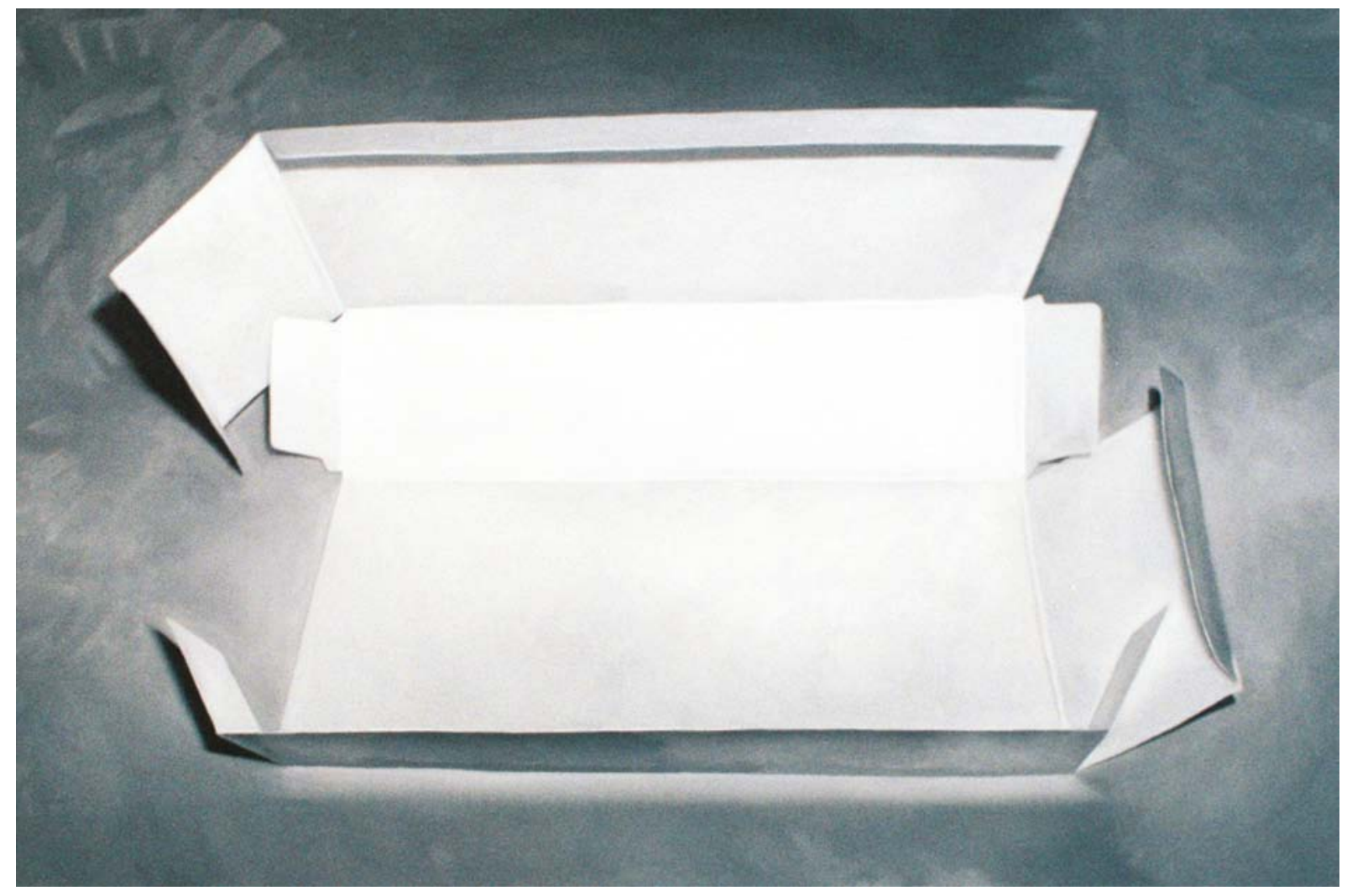

[37]

Uso Externo, 2009

óleo sobre tela. 80 x $120 \mathrm{~cm}$ 


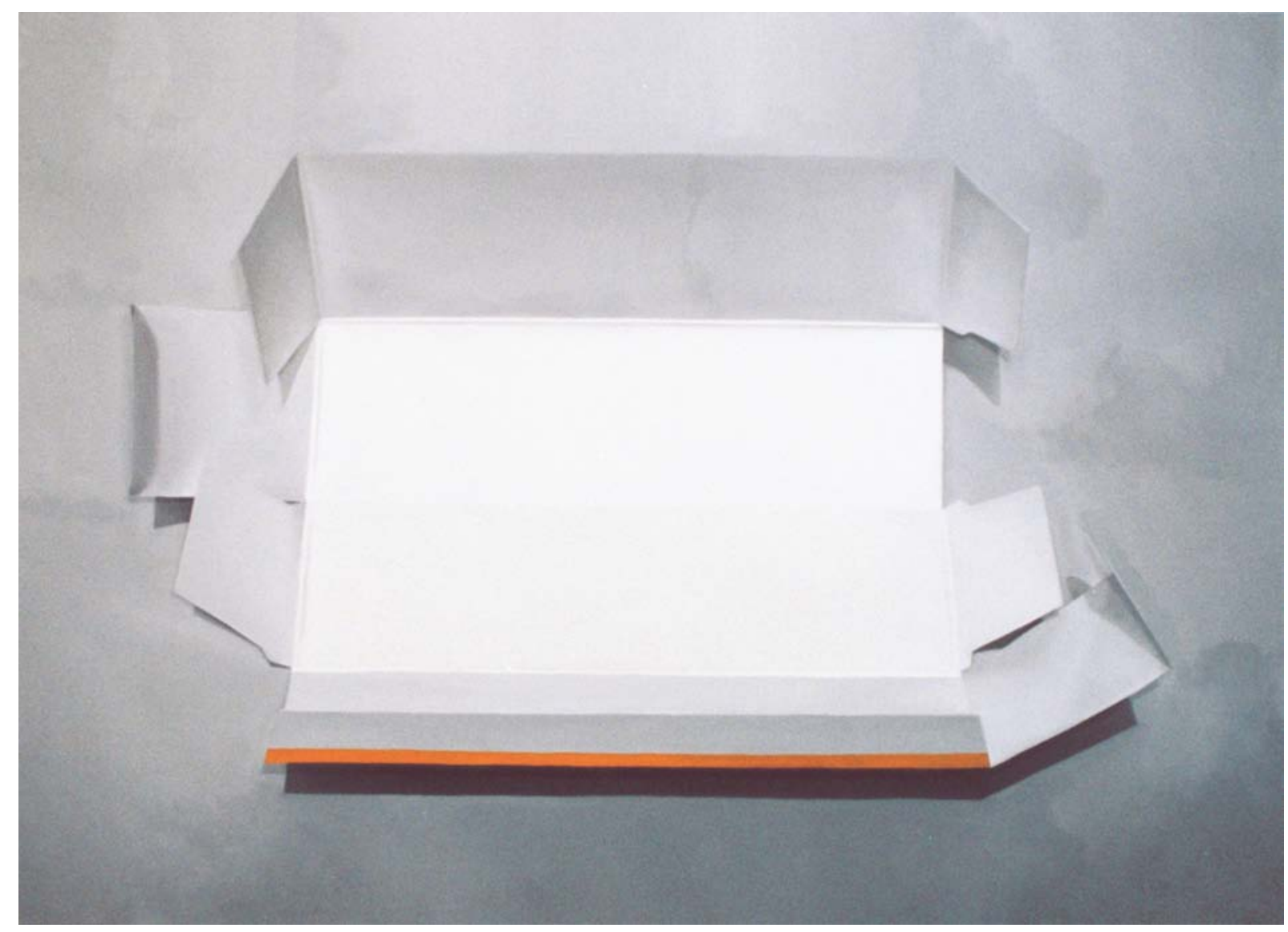

[38]

Tabasco, 2009

óleo sobre tela. $130 \times 180 \mathrm{~cm}$ 


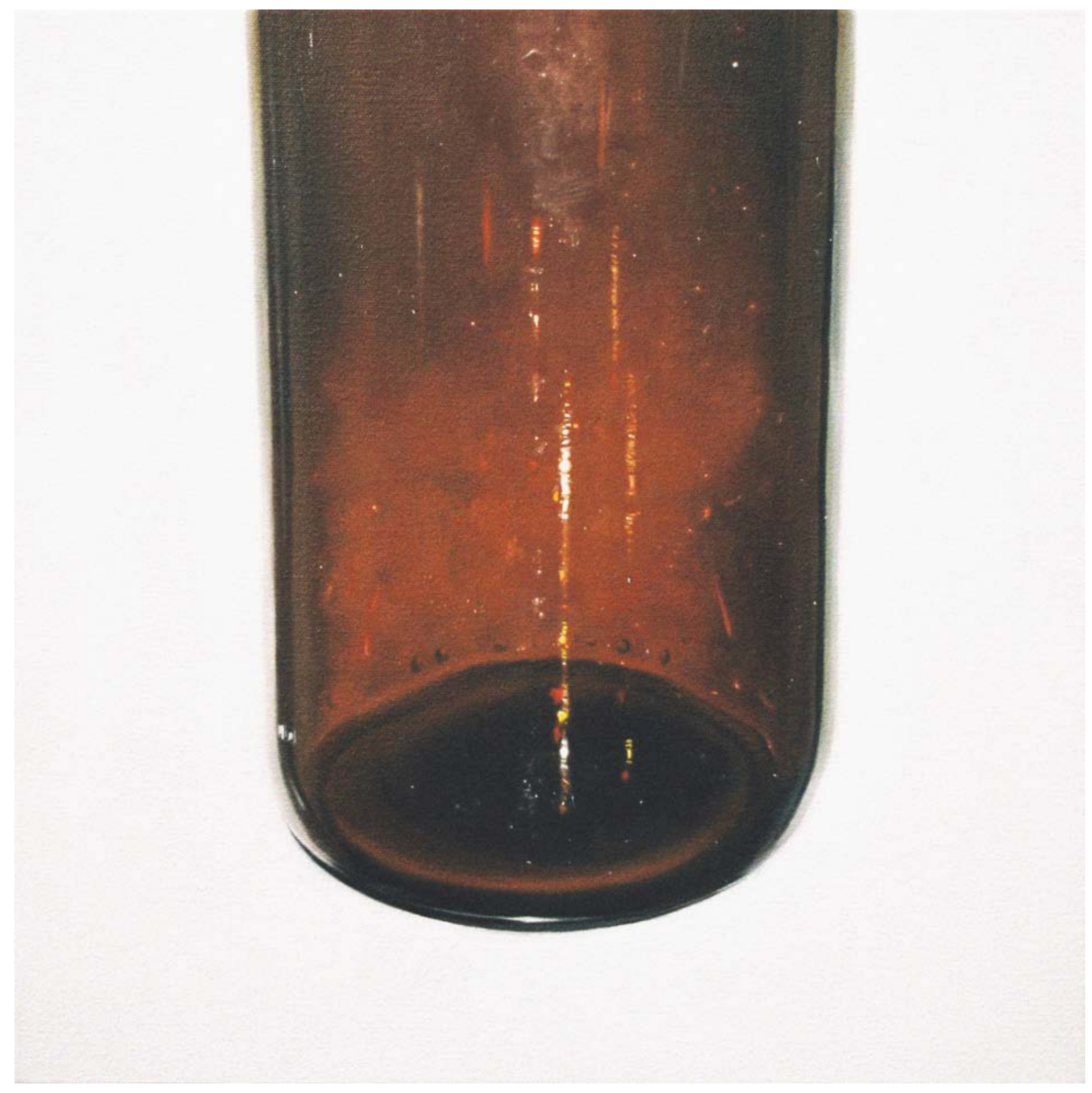

[39]

Festa!, 2009

óleo sobre tela. $40 \times 40 \mathrm{~cm}$ 


\section{Considerações Finais}

Muito mais do que chegar a uma conclusão final, esta dissertação se propôs a funcionar como um meio pelo qual a pesquisa plástica, que deu origem a este trabalho, possa ter continuidade e se desenvolver de uma maneira mais consciente e coerente, se aprofundando cada vez mais nos conceitos investigados, relacionando-se com o contexto da arte atual e criando trabalhos que, de algum modo, possam contribuir com a produção contemporânea. Este arsenal de conhecimentos acumulado durante a elaboração deste texto tem a função de gerar novas reflexões, novos problemas e novas dúvidas que venham a alimentar cada vez mais o trabalho plástico.

Sendo assim, após identificar, organizar e entender os motivos que levaram à criação destas obras, os conceitos envolvidos, o processo criativo, os elementos e técnicas utilizadas para suas materializações e apresentar os resultados obtidos, é possível perceber um interessante paradoxo no qual todo este trabalho plástico se baseia.

Torna-se claro que este desejo de esvaziar a vida cotidiana criando vazios que permitam uma transcendência do cotidiano em uma atividade criativa, transportado para a esfera da arte, traz consigo um paradoxo, já que é necessário povoar o campo artístico, tornando-o repleto de elementos e questões do cotidiano para, a partir de então, ser possível buscar seu esvaziamento. A tela branca - eis um vazio potente - recebe as imagens que espelham o mundo a sua frente, reconstruindo as relações da vida comum para, então, proceder na busca do vazio que foi perdido.

Esta contradição do preencher para se construir um vazio pode soar como um procedimento que se repete em si mesmo eternamente e inutilmente, sem alcançar um resultado diverso do seu ponto de partida. No entanto, é a partir deste procedimento - de adicionar matéria, elementos e conceitos que remetam à vivência cotidiana, servindo como base para a ação de esvaziar - que se inicia uma busca por um novo vazio distinto do original, na tentativa de alcançar um vazio amplificado, tornando-o cada vez mais potente, um vazio que remeta ao sujeito, que nos olhe cada vez mais fundo. 



\section{Bibliografia}

ALIAGA, Juan Vicente; LOOCK, Ulrich; REUST, Hans Rudolf; SPECTOR, Nancy; TUYMANS, Luc. Luc Tuymans. Londres: Phaidon Press, 2003.

BACHELARD, Gaston. A Poética do Espaço. São Paulo: Martins Fontes, 2003.

BARTHES, Roland. A Câmara Clara. Lisboa: Edições 70, 2005.

BAUDRILLARD, Jean. Simulacros e Simulação. Lisboa: Relógio d'Água Editores, 1991.

BENJAMIN, Walter. Magia e Técnica, Arte e Política: Ensaios sobre Literatura e História da Cultura. São Paulo: Editora Brasiliense, 1996.

CHRISTOV-BAKARGIEV, Carolyn; HERBERT, Martin; RUGOFF, Ralph; SCHWABSKY, Barry; SILVERMAN, Kaja. The Painting of Modern Life. Londres: Hayward Publishing, 2007.

COUCHOT, Edmond. Da Representação à Simulação, In: PARENTE, André. Imagem Máquina - A Era das Tecnologias do Virtual. São Paulo: Editora 34, 1993.

DA POIAN, Carmen. Formas do Vazio: Desafios ao Sujeito Contemporâneo. São Paulo: Via Lettera Editora, 2001.

DANTO, Arthur. A Transfiguração do Lugar-comum. São Paulo: Cosac Naify, 2005.

. O Filósofo como Andy Warhol, In: Revista ARS, São Paulo: Departamento de Artes Plásticas - ECA-USP, 2004.

DIDI-HUBERMAN, Georges. O que vemos, o que nos olha. São Paulo: Editora 34, 1998.

FREUD, Sigmund. Edição Stand Brasileira das Obras Psicológicas Completas de Sigmund Freud. Volume XVIII. Além do Princípio de Prazer, Psicologia de Grupo e Outros Trabalhos. Rio de Janeiro: Imago Editora, 1969.

FLUSSER, Vilém. Filosofia da Caixa Preta: Ensaios para uma futura filosofia da fotografia. Rio de Janeiro: Relume Dumará, 2002.

FOSTER, Hal. The Return of the Real. Cambridge: MIT Press, 1996. 
GIANNOTTI, Marco. Andy Warhol ou a Sombra da Imagem, In: Revista ARS, São Paulo: Departamento de Artes Plásticas - ECA-USP, 2004.

LEFEBVRE, Henri. A Vida Quotidiana no Mundo Moderno. Lisboa: Ulisseia, 1969. . Critique of Everyday Life I - Introduction. London: Verso, 2008. Critique of Everyday Life II - Foundations for a Sociology of the Everyday. London: Verso, 2008. . Critique of Everyday Life III - From Modernity to Modernism. London: Verso, 2008.

O'DOHERTY, Brian. No Interior do Cubo Branco. São Paulo: Martins Fontes, 2002.

PIERCE, Charles Sanders. Semiótica. São Paulo: Editora Perspectiva, 1977. PLINIUS SECUNDUS, Caius. Textos de Historia del Arte. Madrid: Visor, 1988.

RAINBIRD, Sean. Gerhard Richter, Londres: Tate Gallery Publications, 1991.

RICHTER, Gerhard. Gerhard Richter Catalogue Raisonne 1993-2004, Düsseeldorf: Richter Verlag, 2005.

ROMAGNOLO, Sergio. O Vazio e o Oco na Escultura. Tese de Doutorado. Departamento de Artes Plásticas - ECA-USP, 2001.

ROSENBERG, Harold, Objeto Ansioso. São Paulo: Cosac \& Naify, 2004.

SANTAELLA, Lucia. Semiótica Aplicada. São Paulo: Thomson, 2005.

SARTRE, Jean-Paul. O Ser e o Nada - Ensaio de Ontologia Fenomenológica. Petrópolis: Vozes, 2008.

TASSINARI, Alberto. O Espaço Moderno. São Paulo: Cosac \& Naify, 2001.

WILKIN, Karen. Morandi. Barcelona: Ediciones Polígrafa, 1998. 